\title{
PRODUÇÃO DAS VARIEDADES CATURRA E MUNDO NOVO DE CAFÉ EM FUNÇÃO DO ESPAÇAMENTO, NÚMERO DE PLANTAS POR COVA E CONDUÇÃO DAS PLANTAS.
}

INÁCIO DE BARROS

Engenheiro Agrônomo

Orientador: Prof. Dr. JOSÉ DIAS COSTA

Dissertação apresentada à Escola Superior de
Agricultura "Luiz de Queiroz", Universidade de São
Paulo, para obtenção do titulo de Mestre em
Agronomia, Área de Concentração: Fitotecnia

PIRACICABA

Estado de São Paulo - Brasil

Julho - 1997 
Dados Internacionais de Catalogação na Publicação (CIP) DIVISÃO DE BIBLIOTECA E DOCUMENTAÇĀO - Campus "Luiz de Queiroz"/USP

Barros, Inácio de

Produçăo das variedades Caturra e Mundo Novo de café em função do espaçamento, número de plantas por cova e condução das plantas / Inácio de Barros. - Piracicaba, 1997.

$82 \mathrm{p}$.

Dissertaçăo (mestrado) -. Escola Superior de Agricultura Luiz de Queiroz, 1997. Bibliografia.

1. Café Mundo Novo (variedade) 2. Café Caturra (variedade) 3. Densidade de plantio 4. Espaçamento 5. Manejo 6. Poda I. Titulo

CDD 633.73 


\section{PRODUÇÃO DAS VARIEDADES CATURRA E MUNDO NOVO DE CAFÉ EM FUNÇÃO DO ESPAÇAMENTO, NÚMERO DE PLANTAS POR COVA E CONDUÇÃO DAS PLANTAS.}

INÁCIO DE BARROS

Aprovada em: 26.08.1997

Comissão julgadora:

Prof. Dr. José Dias Costa

ESALQ/USP

Prof. Dr. José Laércio Favarin ESALQ/USP

Dr. Altino Aldo Ortolani IAC/SAA

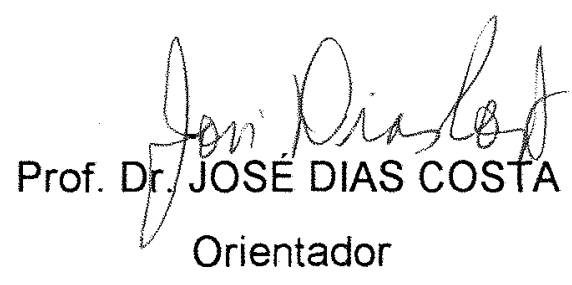


Ao meu amado filho

Arthur, que é a alegria

dos meus dias

\section{DEDICO}

Aos meus queridos pais Mauro e Cristina e à minha dileta esposa Patricia, que sempre me apoiaram, 


\section{AGRADECIMENTOS}

A Deus, por me permitir chegar até aqui;

Ao Instituto Agronômico (IAC), pelo apoio, incentivo e permissão para a realizar o curso;

À Universidade de São Paulo (USP), Conselho Nacional de Desenvolvimento Científico e Tecnológico $(\mathrm{CNPq})$ e ao meu orientador, Prof. Dr. José Dias Costa, pela oportunidade;

Ao Pesquisador Científico Sérgio Vasco de Toledo pela amizade e cessão dos dados utilizados na dissertação e,

Aos amigos, Luiz Enrique (Kike), José Niltom, Walter Rodriguez, Valéria Módolo, César de Castro, Ricardo Kluge, Paulo Araújo, Angelo Jacomino, Regma, Gilson (in memorian) e Shoey pela amizade e pelos deliciosos momentos de convivência. 
SUMÁRIO

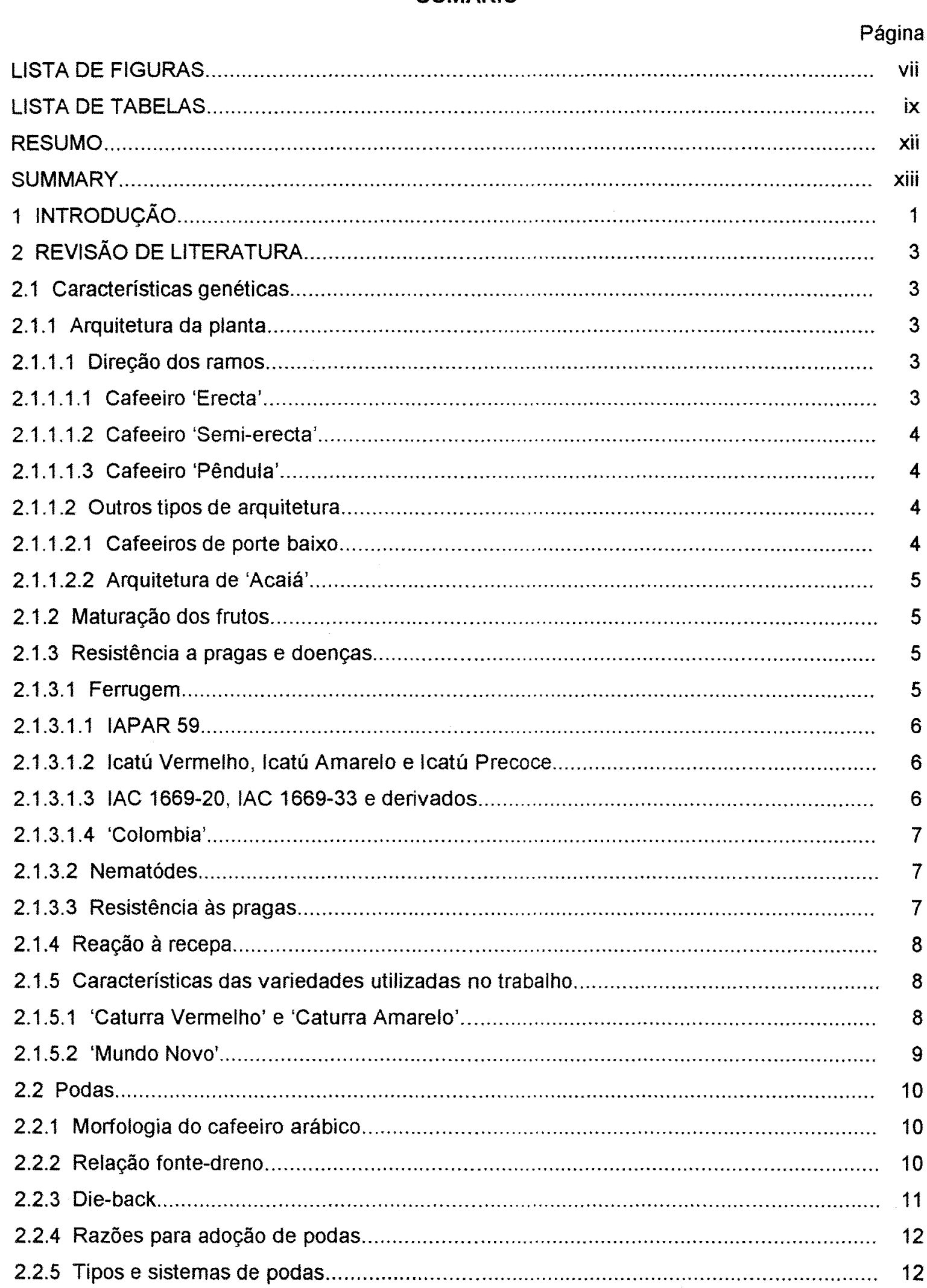




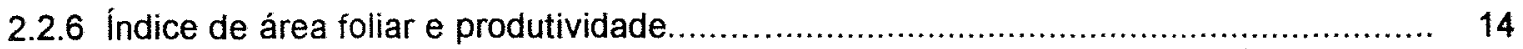

2.2.7 Benefícios da poda na propriedade ............................................................. 15

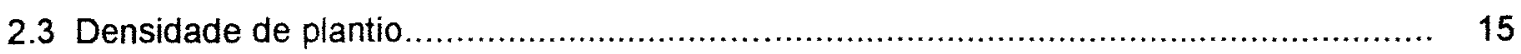

2.3.1 Ajuste do espaçamento ............................................................................... 16

2.3.2 Relação entre densidade de plantio e produtividade ............................................. 16

2.3.3 Fatores que afetam a produção em plantios adensados......................................... 20

2.3.4 influência da densidade de plantio nas condições do solo e uso de

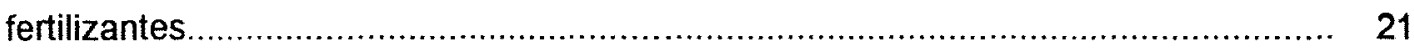

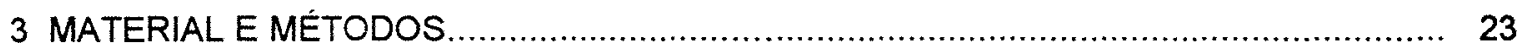

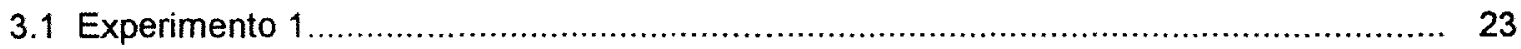

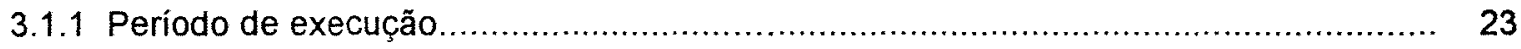

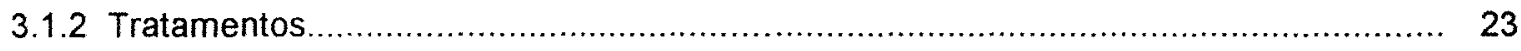

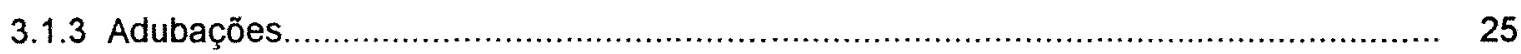

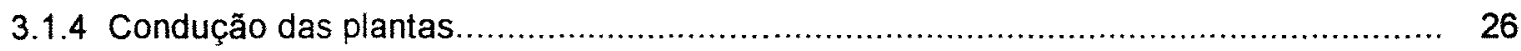

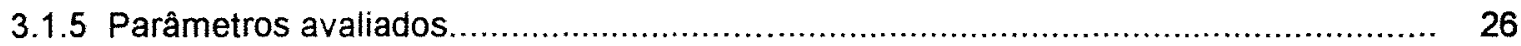

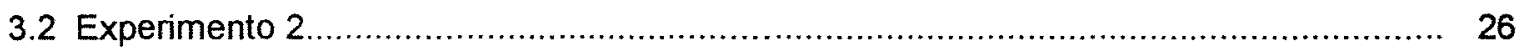

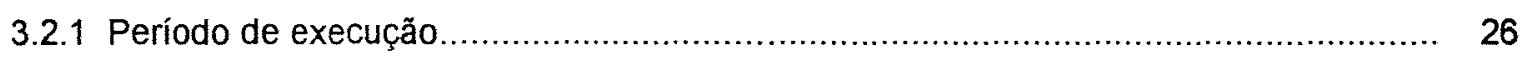

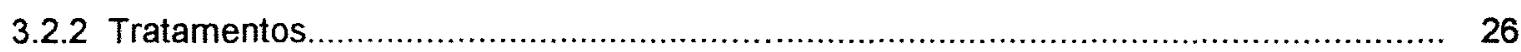

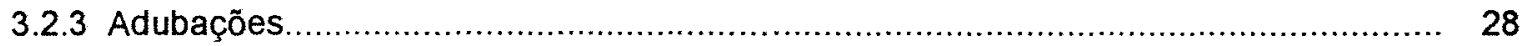

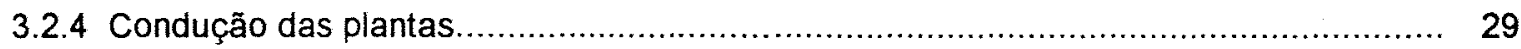

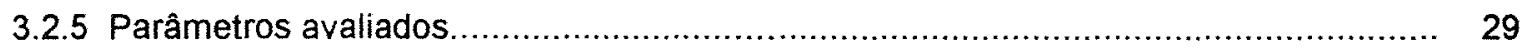

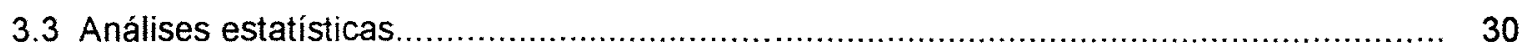

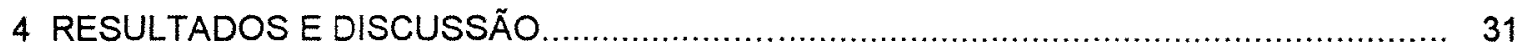

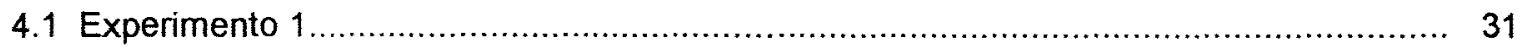

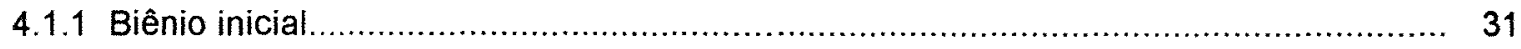

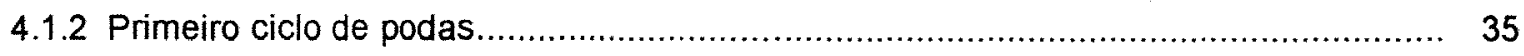

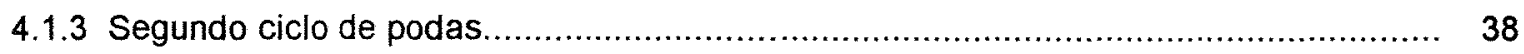

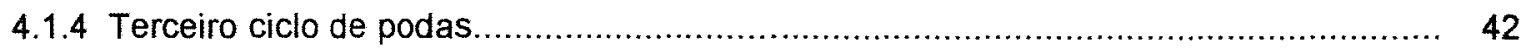

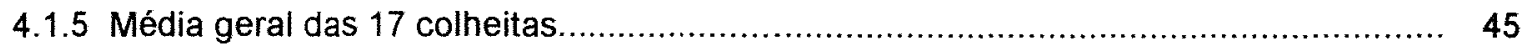

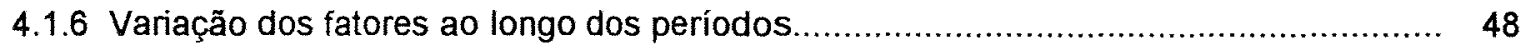

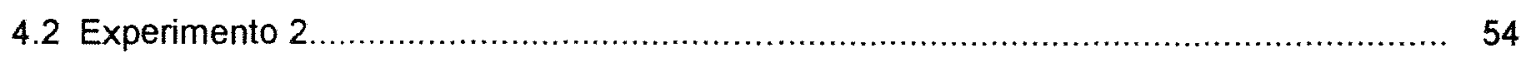

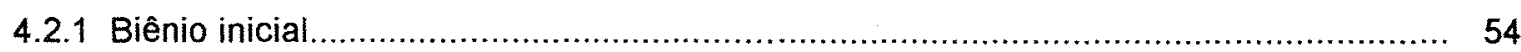

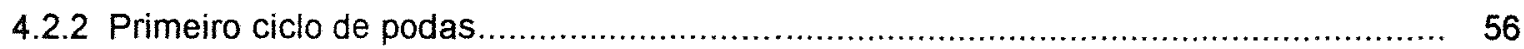

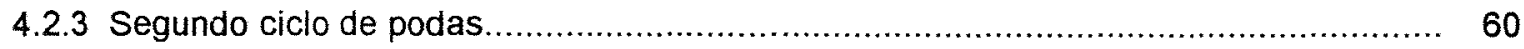

4.2.4 Variação dos fatores ao longo dos periodos..................................................... 62 
Página

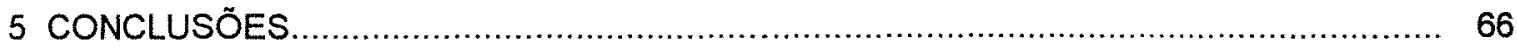

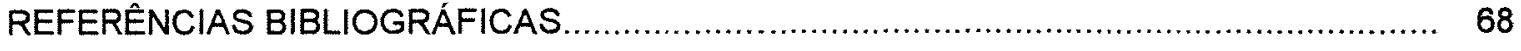

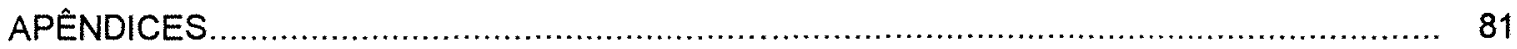




\section{LISTA DE FIGURAS}

Página

1 Gráfico da regressão linear entre a produção de café beneficiado da variedade Caturra, em kg.ha ${ }^{-1}$, e área por cova do biênio inicial (1967-1968) no experimento 1.

2 Gráfico da regressão linear entre a produção de café beneficiado da variedade Caturra, em kg.ha ${ }^{-1}$, e área por cova do primeiro ciclo de podas (1969-1973) no experimento 1

3 Gráfico da regressão linear entre a produção de café beneficiado da variedade Caturra, em kg.ha ${ }^{-1}$, e área por cova do segundo ciclo de podas (1974-1978) no experimento 1

4 Gráfico da regressão linear entre a produção de café beneficiado da variedade Caturra, em kg.ha-1, e área por cova do terceiro ciclo de podas (1979-1983) no experimento 1

5 Gráfico da regressão linear entre a produção de café beneficiado da variedade Caturra, em kg.ha-1, e área por cova do média geral das 17 colheitas (1967-1983) no experimento 1

6 Representação gráfica da produção média de café beneficiado, em kg.ha-1, das variedades testadas ao longo dos períodos estudados - experimento 1

7 Representação gráfica da produção média de café beneficiado, em $\mathrm{kg} \mathrm{ha}^{-1}$, dos sistemas de plantio testados com a variedade Caturra ao longo dos períodos estudados - experimento 1

8 Representação gráfica da produção média de café beneficiado, em $\mathrm{kg}_{\text {ha }}{ }^{-1}$, dos espaçamentos adensados com a variedade Caturra ao longo dos períodos estudados - experimento 1

9 Representação gráfica da produção média de café beneficiado, em $\mathrm{kg} \cdot \mathrm{ha}^{-1}$, com o plantio de 1 ou 2 plantas por cova na variedade Mundo Novo ao longo dos períodos estudados - experimento 1 .

10 Representação gráfica da produção média de café beneficiado, em $\mathrm{kg} \cdot \mathrm{ha}^{-1}$, dos sistemas de plantio testados com a variedade Mundo Novo ao longo dos períodos estudados - experimento 1

11 Representação gráfica da produção média de café beneficiado, em kg.ha- ${ }^{-1}$, dos sistemas de poda testado no espaçamento não adensado com a variedade Mundo Novo ao longo dos períodos estudados - experimento 1 
Página

12 Gráfico da regressão linear entre a produção de café beneficiado, variedade Mundo Novo, em kg.ha ${ }^{-1}$, e área por cova no biênio inicial (1967-1968) do experimento 2... 56

13 Representação gráfica da produção média de café beneficiado, em $\mathrm{kg}_{\text {.ha }}{ }^{-1}$, dos espaçamentos testados ao longo dos períodos estudados - experimento 2 .

14 Representação gráfica da produção média de café beneficiado, em $\mathrm{kg} \mathrm{ha}^{-1}$, dos sistemas de plantio testados ao longo dos periodos estudados com a variedade Mundo Novo - experimento 2

15 Representação gráfica da produção média de café beneficiado, em $\mathrm{kg}^{-\mathrm{ha}^{-1}}$, com o plantio de 1 ou 2 plantas por cova nos espaçamentos adensados ao longo dos períodos estudados com a variedade Mundo Novo - experimento 2.

16 Representação gráfica da produção média de café beneficiado, em $\mathrm{kg}^{-h a^{-1}}$, com o plantio de 1 ou 2 plantas por cova no espaçamento largo ao longo dos períodos estudados com a variedade Mundo Novo - experimento 2 


\section{LISTA DE TABELAS}

1 Relação dos tratamentos do experimento 1

2 Quantidades de nutrientes (em g por metro de sulco) aplicados no plantio do experimento 1

3 Quantidades de nutrientes (em g.cova ${ }^{-1}$ ) aplicados no $2^{\circ}$ e $3^{\circ}$ ano após o plantio do experimento 1

4 Quantidades de nutrientes (em g.cova ${ }^{-1}$ ) aplicados como adubação de produção no experimento 1

5 Relação dos tratamentos do experimento 2

6 Quantidades de nutrientes(em g por metro de sulco) aplicados no plantio do experimento 2

7 Quantidades de nutrientes (em g por cova) aplicados no segundo e terceiro ano após o plantio do experimento 2

8 Quantidades de nutrientes (em g por cova) aplicados como em adubação de produção no experimento 2 .

9 Análise da variância do experimento 1 - Biênio inicial (1967-1968).

10 Médias de produção dos tratamentos do experimento $1 \mathrm{em} \mathrm{kg} \cdot \mathrm{ha}^{-1}$ café beneficiado - Biênio inicial (1967-1968)

11 Médias de produção das variedades estudadas em $\mathrm{kg} \cdot \mathrm{ha}^{-1}$ de café beneficiado Biênio inicial (1967-1968)

12 Médias de produção dos espaçamentos e número de plantas por cova estudados com a variedade Caturra em kg.ha ${ }^{-1}$ de café beneficiado por hectare - Biênio inicial (1967-1968)

13 Análise da variância do desdobramento da interação Espaçamento x Plantas/cova do experimento 1 - Biênio inicial (1967-1968)

14 Análise da variância do experimento 1 - Primeiro ciclo de podas (19691973)

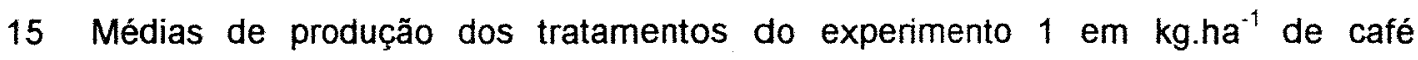
beneficiado - Primeiro ciclo de podas (1969-1973)

16 Médias de produção das variedades estudadas no experimento $1 \mathrm{em} \mathrm{kg} \cdot \mathrm{ha}^{-1} \mathrm{de}$ café beneficiado - Primeiro ciclo de podas (1969-1973).

17 Médias de produção dos espaçamentos e número de plantas por cova estudados com a variedade Caturra em kg.ha ${ }^{-1}$ de café beneficiado - Primeiro ciclo de podas (1969-1973) 
18 Análise da variância do experimento 1 - Segundo ciclo de podas (1974-1978)........ 40

19 Médias de produção das variedades estudadas no experimento 1 , em $\mathrm{kg} \cdot \mathrm{ha}^{-1} \mathrm{de}$ café beneficiado - Segundo ciclo de podas (1974-1978).

20 Médias de produção dos tratamentos do experimento $1 \mathrm{em} \mathrm{kg} \cdot \mathrm{ha}^{-1}$ de café beneficiado - Segundo ciclo de podas (1974-1978).

21 Médias de produção dos espaçamentos e número de plantas por cova estudados com a variedade Caturra em $\mathrm{kg}_{\mathrm{ha}} \mathrm{h}^{-1}$ de café beneficiado - Segundo ciclo de podas (1974-1978)

22 Médias de produção dos sistemas de podas estudados com a variedade Mundo Novo em kg.ha-1 de café beneficiado - Segundo ciclo de podas (1974-1978)........... 41

23 Análise da variância do experimento 1 - Terceiro ciclo de podas (1979-1983)...........

24 Médias de produção das variedades estudadas no experimento 1 , em kg.ha-1 de café beneficiado - Terceiro ciclo de podas (1979-1983).

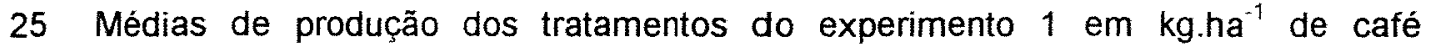
beneficiado - Terceiro ciclo de podas (1979-1983)......

26 Médias de produção dos espaçamentos e número de plantas por cova estudados com a variedade Caturra em $\mathrm{kg} \cdot \mathrm{ha}^{-1}$ de café beneficiado - Terceiro ciclo de podas (1979-1983).

27 Médias de produção dos sistemas de podas estudados com a variedade Mundo Novo em kg.hat de café beneficiado - Terceiro ciclo de podas (1979-1983).

28 Médias de produção dos tratamentos do experimento $1 \mathrm{em} \mathrm{kg}_{\text {.ha }}{ }^{-1}$ de café beneficiado - Média geral das 17 colheitas (1967-1983).

29 Análise da variância do experimento 1 - Média geral das 17 colheitas (19671983).

30 Médias de produção das variedades estudadas no experimento $1 \mathrm{em} \mathrm{kg} \cdot \mathrm{ha}^{-1} \mathrm{de}$ café beneficiado - Média geral das 17 colheitas (1967-1983).

31 Médias de produção dos espaçamentos e número de plantas por cova estudados com a variedade Caturra em $\mathrm{kg} \cdot \mathrm{ha}^{-1}$ de café beneficiado por hectare - Média geral das 17 colheitas (1967-1983).

32 Médias de produção dos sistemas de podas estudados com a variedade Mundo Novo em kg.ha ${ }^{-1}$ de café beneficiado - Média geral das 17 colheitas (1967-1983)......

33 Análise da variância do experimento 2, com a variedade Mundo Novo - Biênio inicial (1966-1967).

34 Médias de produção dos tratamentos do experimento 2 com a variedade Mundo Novo, em kg.hat de café beneficiado - Biênio inicial (1966-1967). 
35 Análise da variância do experimento 2 - Primeiro ciclo de podas (1968-1972).....

36 Médias de produção, em $\mathrm{kg} \cdot \mathrm{ha}^{-1}$ de café beneficiado em função do tipo de plantio e número de plantas por cova com a variedade Mundo Novo no experimento 2 Primeiro ciclo de podas (1968-1972).

37 Médias de produção dos tratamentos do experimento 2, com a variedade Mundo Novo, em kg.ha-1 de café beneficiado - Primeiro ciclo de podas (1968-1972).

38 Análise da variância do desdobramento da interação Espaçamento x Plantas por cova com a variedade Mundo Novo no experimento 2 - Primeiro ciclo de podas (1968-1972)

39 Médias de produção dos espaçamentos adensados com a variedade Mundo Novo no experimento 2 , em kg.ha-1 de café beneficiado - Primeiro ciclo de podas (19681972)

40 Médias de produção dos espaçamentos, tipos de poda e número de plantas por

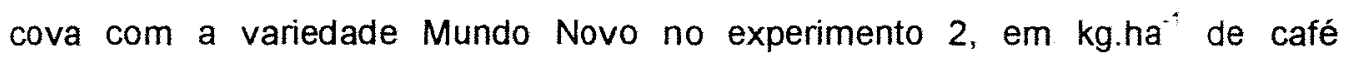
beneficiado - Primeiro ciclo de podas (1968-1972).

41 Análise da variância do experimento $2 \mathrm{com}$ a variedade Mundo Novo - Segundo ciclo de podas (1973-1977).

42 Médias de produção, em função do tipo de plantio e número de plantas por cova com a variedade Mundo Novo no experimento $2 \mathrm{em} \mathrm{kg} \cdot \mathrm{ha}^{-1}$ de café beneficiado Segundo ciclo de podas (1973-1977)

43 Médias de produção dos tratamentos do experimento 2 com a variedade Mundo Novo, em kg.ha ${ }^{-1}$ de café beneficiado - Segundo ciclo de podas (1973-1977).

44 Médias de produção dos espaçamentos adensados com a variedade Mundo Novo, em kg.ha ${ }^{-1}$ de café beneficiado no experimento 2 - Segundo ciclo de podas (19681972).

45 Médias de produção dos espaçamentos, tipos de poda e número de plantas por cova com a variedade Mundo Novo no experimento 2, em kg.ha ${ }^{-1}$ de café beneficiado - Segundo ciclo de podas (1973-1977) 


\section{PRODUÇÃO DAS VARIEDADES CATURRA E MUNDO NOVO DE CAFÉ EM FUNÇÃO DO ESPAÇAMENTO, NÚMERO DE PLANTAS POR COVA E CONDUÇÃO DAS PLANTAS}

Autor: INÁCIO DE BARROS

Orientador: Prof. Dr. JOSÉ DIAS COSTA

\section{RESUMO}

Com o objetivo de avaliar a influência da densidade de plantio, número de plantas por cova e do manejo de podas programadas sobre a produção das variedades 'Caturra' e 'Mundo Novo' de café, foram conduzidos dois experimentos no Centro Experimental do Instituto Agronômico em Campinas durante o período de 1963 a 1983. No primeiro experimento, foram estudadas cinco espaçamentos $\quad(1,62 \times 0,62 \mathrm{~m} ; 2,0 \times 1,0 \mathrm{~m} ; 2,3 \times 1,3 \mathrm{~m} ; 2,79 \times 1,79 \mathrm{~m}$ e 3,0 $\times 2,0 \mathrm{~m}$ ) combinados com uma ou duas plantas por cova e conduzidas sem podas, decotadas a $2 \mathrm{~m}$ de altura e recepadas em esquema pré-determinado tipo Beaumont \& Fukunaga, com as variedades 'Caturra' e 'Mundo Novo' pelo periodo de 17 colheitas. No segundo experimento foram estudados três espaçamentos $(3,0 \times 2,0 ; 2,5 \times 1,5$ e 2,0 $\times 1,0 \mathrm{~m})$, combinados com uma ou duas plantas por cova e conduzidos sem podas, decotadas a $2 \mathrm{~m}$ de altura, recepadas em esquema fixo tipo Beaumont \& Fukunaga e recepadas em ruas alternadas após duas colheitas e em área total após sete colheitas com a variedade de 'Mundo Novo' pelo periodo de 12 colheitas. Os resultados demonstraram que altas densidades de plantio apresentaram elevadas produções nas primeiras safras com acentuado decréscimo após sete colheitas para as duas variedades, independentemente da aplicação de podas; a variedade 'Mundo Novo' manteve o potencial produtivo enquanto que 'Caturra' diminui sensivelmente a produção ao longo dos anos, evidenciando o baixo vigor da segunda. A utilização de duas plantas por cova favoreceu ao aumento na produção para plantio não adensado. A adoção de podas programadas não influenciou na produção das variedades estudadas. 
Author: INÁCIO DE BARROS

Adviser: Prof. Dr. JOSÉ DIAS COSTA

\section{SUMMARY}

Aiming the evaluation of two coffee variedades ('Caturra' and 'Mundo Novo') in several plant densities, number of plants per hole and pruning systems, two experimental trials were carried out in Campinas, from 1963 to 1983 . In the first, five plant spacings $(1,62 \times 0,62 \mathrm{~m} ; 2,0 \times$ $1,0 \mathrm{~m} ; 2,3 \times 1,3 \mathrm{~m} ; 2,79 \times 1,79 \mathrm{~m}$ and $3,0 \times 2,0 \mathrm{~m})$ along with one and two plants/hole, were studied the following three pruning systems: a) no pruning; b) capped at $2 \mathrm{~m}$ height and c) Beaumont \& Fukunaga for a period of 17 harvests. In the second, only for the variedade 'Mundo Novo' was tested, three spacings $(3,0 \times 2,0 \mathrm{~m} ; 2,5 \times 1,5 \mathrm{~m}$ and $2,0 \times 1,0 \mathrm{~m})$, utilizing one and two plants/hole, were checked following four pruning systems (the three above mentioned and $d$ ) capping in alternate rows after the second harvest, followed by overall cappings after the seventh harvest), for a period of 12 harvests. The higher the plant densities (closer spacings) the higher the seed yields up to the seventh harvest; after that, there was a sharp decrease in seed yields for both variedades (only in the higher plant densities), even applying several pruning systems. The use of two plants/hole caused an increase in seed yields in larger spacings while the pruning systems tested did not affect the seed yields potential of the variedades studied. 'Mundo Novo' variedade showed a much more stead seed yields ability than 'Caturra' during the test period. 


\section{INTRODUÇÃO}

Muitos pontos passaram a ser relevantes ao café brasileiro com a extinção do IBC, tal como a qualidade do produto, que anteriormente não era levada em conta na política governamental de adquirir o excedente da produção interna e passou a ser questão crucial no cenário de livre comércio, tomando posição prioritária das lideranças do setor (Bertone, 1992). Outro ponto a merecer destaque é a adoção de um processo agressivo de marketing (Moricochi \& Martin, 1993).

Quanto a produtividade, o país convive com uma situação de baixíssima eficiência técnica, uma vez que a produtividade média é inferior a 10 sacas beneficiadas por hectare por ano, todavia são comuns casos de produtores com produtividade acima de 30 sacas. Com a adoção de manejos não convencionais, existem produtores com faixas de produtividade acima de 50 sacas. Mesmo em situações desfavoráveis de mercado, produtividades acima de 20 sacas proporcionam retornos satisfatórios. Já existem em órgãos públicos e privados de pesquisa tecnologias à disposição do setor produtivo para mudar o quadro de produtividade da cafeicultura brasileira (Moricóchi\& Martin, 1993).

No período de outubro de 1992 a abril de 1994 houve uma retomada de crescimento nos preços internacionais do café devido principalmente a uma redução nos estoques mundiais que eram da ordem de 48,5 milhões de sacas à época do fim do AlC e atingiram o patamar de 30,9 milhões de sacas no período $1994 / 1995$, provocada em parte pela redução da produção brasileira desde 1988. Os preços têm se mantido satisfatórios desde então, com previsões de estender-se até 1998 (Bacha, 1996). Esse aquecimento nos preços promoveu euforia quanto as perspectivas do segmento e uma busca, pelo setor produtivo, de novas tecnologias para o aumento da produtividade e melhoria da qualidade do produto, já que até as torrefadoras nacionais, responsáveis pelo mercado interno, passaram a adotar uma política de valorização do produto através de programas como o de selo de pureza promovido pela Associação Brasileira das Indústrias de Torrefação e Moagem de Café ( $A B I C)$, desvalorizando cafés de baixa qualidade.

Dentre as opções de novas tecnologias, o adensamento das lavouras tem sido o mais buscado pelos produtores e gerado as maiores polêmicas entre os técnicos. Fundamentalmente 
a elevação da densidade de plantas, melhor tecnologia de colheita e de preparo do café possibilitam a obtenção de um produto final com preço diferenciado (Martin et al., 1995).

Os defensores do sistema apresentam como razões fundamentais o menor custo de produção por saca em virtude da maior produção por área (Matsunaga, 1981) e a liberação de áreas da propriedade para cultivos alternativos (Martin et al., 1995). Todavia, Barros (1994), argumenta vários aspectos a serem considerados quando da opção pelo adensamento, tais como: necessidade de manejo das lavouras com podas programadas, aumento na incidência de ataque pela broca, em virtude de seu difícil controle nessa situação e o aumento da mão-deobra sazonal, o que para certas regiões do Estado de São Paulo traria concorrência com a colheita da cana-de-açúcar e da laranja.

O objetivo da presente dissertação foi avaliar a influência da densidade de plantio como função do espaçamento, do número de plantas por cova e do manejo de podas programadas sobre a produção das variedades Caturra e Mundo Novo de café. 


\section{REVISÃO DE LITERATURA}

\subsection{Características genéticas}

O uso do plantio adensado em cafezais, associado à utilização de variedades adequadas e com manejo eficiente, com certeza aumentará a curto prazo a produção por área em niveis bem mais elevados que o plantio aberto e de livre crescimento (Fazuoli, 1994). Conforme o adensamento utilizado, poderão ocorrer profundas mudanças no cafezal formado tais como: maturação mais tardia; mudanças na fauna e flora microbiana; sistema radicular; crescimento do cafeeiro; fertilidade do solo; melhor aproveitamento de nutrientes pelas plantas; incidência de pragas e moléstias, etc (Montenegro, 1962; Mitchel, 1976; Matiello, 1991).

\subsubsection{Arquitetura da Planta}

\subsubsection{Direção dos ramos}

No cafeeiro "Arábica" ou "Típica", o ângulo que os ramos laterais fazem com a haste principal é, em média, de $67^{\circ}$, variando de 50 a $85^{\circ}$. Alguns mutantes de $C$. arabica formam diferentes ângulos, dando diferentes formatos à copa e poderão fornecer caracteres genéticos propícios ao adensamento das lavouras (Fazuoli, 1994). São eles:

\subsubsection{Cafeeiro 'Erecta'}

Em cafeeiros desse mutante, o ângulo médio é de $26^{\circ}$ com variação de 11 a $41^{\circ}$. Mesmo apresentando crescimento vertical, verifica-se que os ramos laterais continuam a manter todas as características de ramos plagiotrópicos (Carvalho et al., 1991). A enxertia de ramos laterais de 'Erecta' produzem plantas de baixa estatura e com apenas ramos plagiotrópicos (Carvalho \& Antunes Filho, 1952), confirmando o dimorfismo característico dos ramos do cafeeiro. No Estado de São Paulo, cafeeiros 'Erecta' foram encontrados em Campinas e Cravinhos, no entanto, não se sabe se possuem a mesma origem ou se foram trazidos de outros paises, já que foram descritos como variedade distinta de $C$. arabica na Indonésia (Cramer, 1913).

O uso dessa variedade em programas de melhoramento mostrou que o par de fatores, a qual se deu o símbolo Er é dominante (Krug \& Carvalho, 1950). Em virtude disso, híbridos $F_{1}$ de 
cafeeiros 'Erecta' e 'Arábica' apresentam ramos eretos e, em $F_{2}$ verifica-se uma segregação de $3: 1$ de plantas eretas e normais.

A sua produtividade é muito baixa, mas pode ser plantado em altíssimas densidades.

Segundo Fazuoli (1994) foram realizadas hibridações entre a variedade Catuaí Vermelho de $C$. arabica e 'Erecta' com o objetivo de reduzir o porte da planta, em virtude do fator $C t$ de Catuaí, e ramos eretos. A combinação Catuaí-Erecta poderá ser viável em plantios adensados, contudo precisa ser melhor avaliada (Fazuoli, 1994).

\subsubsection{Cafeeiro 'Semi-erecta'}

Plantas com ramificação semi-erecta são encontradas em materiais oriundos da Etiópia, porém não está relacionado com as plantas 'Erecta'. O fator 'semi-erecta' parece ser recessivo e é de difícil classificação (Carvalho, 1959). Esse fator, bem como o 'Erecta', pode ser transferido a variedades comerciais, alterando sua arquitetura, deixando-os mais apropriados a plantios adensados.

\subsubsection{Cafeeiro 'Pêndula'}

Mutante de C. arabica encontrado em Botucatu, Estado de São Paulo, cujos ramos laterais são pendentes fazendo ângulo com a haste principal maior que o 'Arábica'. Nas plantas adultas, os ramos laterais são pendentes, dai sua denominação. Cafeeiros com essa caracteristica foram descritos por Cramer (1913) como pertencentes à variedade 'Pêndula' (Krug et al., 1938). Híbridos $F_{1}$ entre 'Erecta' e 'Pêndula' apresentam ramos eretos, porém, com as extremidades pendentes, constituindo um exemplo diferente de interação entre fatores.

\subsubsection{Outros tipos de arquitetura}

\subsection{Cafeeiros de porte baixo}

A característica de porte baixo, conferida pela redução no tamanho dos internódios, é controlada por fatores genéticos que podem ser: Ct-Caturra, Sb-São Bernardo, VIVila Lobos ou Sr-San Ramon, todos dominantes (Carvalho et al., 1984; Carvalho et al., 1991). As variedades que possuem o alelo $C t$ apresentam porte baixo e são mais produtivas, enquanto as variedades que apresentam os outros alelos são menos produtivas (Fazuoli, 1994).

Os cafeeiros de porte baixo, possuem de modo geral, arquitetura adequada a plantios adensados, por permitir um maior número de plantas por unidade de área. 


\subsection{Arquitetura de 'Acaiá'}

A variedade Acaiá possui uma arquitetura muito boa para plantios densos, pois os ramos laterais são mais curtos. O seu principal inconveniente é a altura exagerada, que pode ser controlada por meio de podas a fim de manter a planta em uma altura adequada à colheita (Fazuoli, 1994).

\subsubsection{Maturação dos frutos}

No sistema adensado, as variedades de café normalmente mudam seu comportamento com relação à maturação dos frutos, tornando-se mais tardia, independente da região. De forma geral, constitui-se em problema, principalmente em regiões altas e frias, já que os cafeeiros nessas condições se tornam bem mais tardios, inviabilizando muitas vezes o seu plantio (Fazuoli, 1994).

Dentre os cafeeiros de porte baixo indicados para plantios adensados, Catuaí Vermelho e Catuaí Amarelo atrasam consideravelmente a maturação em áreas mais frias, sendo portanto mais apropriadas para regiões mais quentes.

As outras variedades de porte baixo não foram ainda devidamente analisadas em plantios adensados no Brasil (Fazuoli, 1994).

Dentre as variedades de porte alto, Acaiá apresenta bom comportamento de maturação em plantios adensados e deve ser preferida em relação às demais (Fazuoli, 1994).

\subsubsection{Resistência a pragas e doenças}

Quando se adota plantios adensados de café, as condições da lavoura a instalação e 0 desenvolvimento das principais doenças do cafeeiro (Matiello, 1991).

\subsubsection{Ferrugem}

Existem atualmente cerca de 39 raças de ferrugem. No Brasil, foram constatadas cerca de 12 raças (Rodriguez Júnior et al., 1975; Bettencourt \& Rodriguez Júnior, 1988; Kushalappa \& Eskes, 1989; Fazuoli, 1991).

No Brasil e no exterior desenvolvem-se programas de pesquisa visando obter variedades resistentes ao agente da ferrugem.

Pelo fato de poderem apresentar resistência especifica e principalmente não específica às raças conhecidas do patógeno, vem sendo dada especial atenção aos híbridos naturais ou artificiais entre as espécies C. arabica e C. canephora, como 'Híbrido de Timor', 'Arabusta', 
'Icatú', 'Catimor' e outros (Carvalho et al., 1989a; Carvalho et al., 1991; Carvalho \& Fazuoli, 1993).

Dentre as variedades e seleções resistentes à ferrugem, os principais são:

\subsection{IAPAR 59}

Lançada em 1993 pelo Instituto Agronômico do Paraná, esta variedade apresenta porte baixo, resistência ao agente causador da ferrugem. É derivada do cruzamento entre 'Vila Sarchi' e 'Hibrido de Timor' indicada para plantios preferencialmente adensados em virtude de possuir menor altura e diâmetro que o 'Mundo Novo' e 'Catuaí'. Possui grãos que apresentam peneira média 16 e é susceptivel a Cercospora coffeicola. Pseudomonas siringae p.v. garcae e ao bicho mineiro (Perileucoptera coffeella) (IAPAR, 1993).

\subsection{Icatu Vermelho, Icatu Amarelo e Icatu Precoce}

Do cruzamento entre $C$. canephora $\mathrm{cv}$. Robusta e $C$. arabica cv. Bourbon Vermelho e sucessivos retrocruzamentos com $C$. arabica cv. Mundo Novo, deu origem a variedade 'Icatu' Vermelho, de porte alto, rústica, produtiva e com resistência específica e não especifica ao agente patológico da ferrugem. Já as variedades 'Icatu Amarelo' e 'Icatu Precoce' foram obtidas pelo cruzamento natural de 'Icatu Vermelho' com 'Bourbon Amarelo' (Monaco \& Carvalho, 1975; Carvalho et al., 1989a; Fazuoli, 1986; Fazuoli, 1991). O adensamento das lavouras com as variedades de 'Icatu' deve ser mais ameno em virtude do elevado vigor, rusticidade, maior altura e diâmetro da copa.

\subsection{IAC 1669-20, IAC $1669-33$ e derivados}

Derivada do cruzamento de 'Vila Sarchi' com o 'Híbrido de Timor', de linhagens IAC 1669-20 e IAC 1669-33 foram selecionadas no IAC (Carvalho et al., 1989b).

Apresentam produção elevada (Costa et al., 1983), bom vigor, resistência à ferrugem, porte baixo, frutos de coloração vermelha e maturação tardia. Apresentam também boa reação de brotação após recepa, o que constitui vantagem em plantios adensados e o tamanho de suas sementes é, geralmente, maior que as do 'Catuaí'.

Da linhagem IAC 1669-20 foram selecionadas plantas que receberam a designação de IAC 4092 e IAC 4275, todas muito promissoras para plantios adensados e da linhagem IAC 1669-33 foram selecionadas as linhagens IAC 4093, IAC 4094, IAC 4095 e IAC 4096, também muito promissoras para plantios adensados (Fazuoli, 1994). 


\subsubsection{4. 'Colombia'}

É uma variedade composta de várias linhagens de porte baixo. É derivada do cruzamento de 'Caturra Vermelho' e 'Caturra Amarelo' com o 'Hibrido de Timor', apresentando porte baixo, frutos vermelhos ou amarelos e resistência à ferrugem. O seu aspecto fenotípico, as características dos frutos e das sementes são semelhantes à variedade Caturra (Castilho \& Moreno, 1987).

\subsubsection{Nematóides}

Até o momento tem-se recomendado a enxertia hipocotiledonar das variedades de $C$. arabica no porta-enxerto 'Apoatã' de C. canephora. Esse porta-enxerto apresenta resistência a Meloidogyne exigua e às raças de $M$. incognita existentes em São Paulo (Fazuoli, 1986; Fazuoli et al., 1987).

Em germoplasmas de 'Icatu' e derivados de 'Híbrido de Timor', têm sido feitas seleções de cafeeiros com tolerância ou resistência aos nematóides e assim dispensar o emprego da enxertia, que é de custo elevado (Fazuoli et al., 1987; Gonçalves \& Ferraz, 1987; Gonçalves, 1993). Tem-se procurado associar a resistência a nematóides e ao agente da ferrugem (Fazuoli et al., 1987).

\subsubsection{Resistência às pragas}

Em locais quentes e espaçamentos abertos, o bicho mineiro (Perileucoptera coffeella) é a praga mais importante. No entanto, até o presente momento e para as variedades plantadas comercialmente, independente da região, essa praga passa a não ser importante quando se trata de plantios adensados (Matiello, 1991).

Já a broca do café (Hypotenemus hampel), tem grande importância e aumenta sua incidência em plantios adensados, além de ser de difícil controle nessas condições (Barros, 1994). Até o momento, não existem fontes de resistência à broca, o que inviabiliza um programa de melhoramento. Para plantios adensados, o controle biológico parece ser a melhor alternativa; no entanto, as pesquisas são ainda recentes e o controle químico é o mais utilizado (Fazuoli, 1994). 


\subsubsection{Reação à Recepa}

A reação à recepa é muito importante quando se trata de plantios adensados, já que esta será utilizada com frequência nesse tipo de plantio (Fazuoli, 1994).

Cafeeiros 'Mundo Novo' e 'Acaiá' rebrotam bem quando recepados. Já 'Bourbon Amarelo', 'Catuaí Vermelho' e 'Catuai Amarelox, nas condições do Estado de São Paulo, apresentam rebrota apenas razoável, variando amplamente em função da idade e estado nutricional das lavouras (Fazuoli, 1994).

'Icatu' tem apresentado ótima capacidade de brotação ao ser recepado, o mesmo tem ocorrido com as linhagens de porte baixo resistentes à ferrugem IAC 1669-20 e IAC 1669-33 em Mococa, SP (Fazuoli, 1994), bem como com a 'IAPAR 59' (IAPAR, 1993).

\subsubsection{Características das variedades utilizadas no trabalho}

\subsubsection{1. 'Caturra Vermelho' e 'Caturra Amarelo'}

São variedades provavelmente originárias de Minas Gerais ou Espírito Santo por uma mutação de 'Bourbon Vermelho'. Suas sementes foram introduzidas no Instituto Agronômico de Campinas em 1937, oriundas de Siqueira Campos, Estado do Espirito Santo. As informações obtidas mostram que os mutantes surgiram pelo menos 22 anos antes da introdução da variedade no IAC (Krug et al., 1949). Todavia, esses mutantes passaram a ser aprimorados através de seleções após a sua introdução no IAC.

Suas principais caracteristicas são: porte reduzido, por apresentar internódios mais curtos, tanto dos ramos ponteiros quanto dos laterais, o que confere um aspecto compacto à planta. Sua produção é elevada, tendo o epicarpo dos frutos coloração vermelha no 'Caturra Vermelho' e amarela no 'Caturra Amarelo'. Por tratar-se da primeira mutação de café que apresenta porte reduzido e produção elevada, estas variedades deram grande contribuição aos programas de melhoramento genético do IAC (Carvalho et al., 1991) e consequentemente do Brasil. As características de porte reduzido dessas variedades são conferidas por um par de fatores genéticos dominantes CtCt (Carvalho et al., 1984), o que facilita os programas de melhoramento.

Um dos principais entraves da utilização dessas variedades no Brasil foi a falta de vigor após algumas colheitas. Talvez, devido a maturação dos frutos mais precoce que esta 
variedade apresenta, ela poderia ser experimentada em plantios adensados em locais de altitudes elevadas e em solos férteis (Fazuoli, 1994).

\subsubsection{2. 'Mundo Novo'}

A variedade Mundo Novo corresponde a uma recombinação, resultante do cruzamento natural entre as variedades Sumatra e Bourbon Vermelho de Coffea arabica, que ocorreu no município de Mineiros do Tietê, Estado de São Paulo. Algumas sementes desses cafeeiros foram plantadas no municipio de Mundo Novo, que posteriormente passou a se chamar Urupês, Estado de São Paulo. Nesta localidade, foram realizadas entre 1943 a 1952, seleções de várias plantas matrizes que deram origem a variedade. As plantas selecionadas sofreram assim, seleções entre e dentro das progênies, onde procurou-se eliminar os vários defeitos encontrados na população original. Algumas dessas seleções, $S_{1}$ e $S_{2}$, então denominadas de Mundo Novo, foram multiplicadas e distribuidas aos cafeicultores (Carvalho et al., 1952; Fazuoli, 1977).

Em experimentos conduzidos em Campinas, Jaú e Mococa, todos municipios paulistas, as melhores progênies de 'Mundo Novo' chegaram a produzir $80 \%$ a mais que o material original, $50 \%$ a mais que as melhores seleções de 'Bourbon Amarelo', 95\% a mais que as melhores seleções de 'Bourbon Vermelho' e $240 \%$ a mais que as progênies de 'arábica' ('Nacional' ou 'Típica') (Carvalho et al., 1964; Monaco et al., 1965).

As suas linhagens se caracterizam por elevada produção de café beneficiado, aliado a bom vigor. Nas condições de Campinas, o periodo médio da fertilização até a maturação dos frutos é de 224 dias (Fazuoli, 1994).

Em experimentos da Seção de Genética do IAC. as linhagens de 'Mundo Novo' apresentam uma produção média anual de $2.000 \mathrm{~kg}$ ha ${ }^{-1}$, incluindo as primeiras produções após o plantio, com uma oscilação entre 1.500 a $3.000 \mathrm{~kg}^{-h^{-1}}$. Em plantios adensados, essas produções podem ser ampliadas, principalmente nas quatro primeiras colheitas, com valores que variam de acordo com o espaçamento adotado. Em anos de elevada produção, pode atingir até $6.000 \mathrm{~kg} \cdot \mathrm{ha}^{-1}$ de café beneficiado (IAC, 1980).

Atualmente, diversas linhagens de 'Mundo Novo' são indicadas para plantio: IAC LCMP376-4, IAC LCP379-19, IAC LCP388-17, IAC LCMP388-17-1, IAC LCMP388-6, IAC LCP464-12, IAC LCP515-20, IAC LCP501-5, IAC LCP502-19 e IAC LCP467-11. Várias outras linhagens encontram-se em estudo, tanto no Estado de São Paulo quanto em outras regiões do Brasil (Fazuoli, 1994). 
Os cafeeiros 'Mundo Novo' têm apresentado boas produções em quase todas as regiões cafeeiras do Brasil, com clima apropriado para C. arabica, mostrando ampla capacidade de adaptação (Fazuoli, 1994).

Dentre as linhagens apresentadas, IAC LCMP376-4, IAC LCP379-19, IAC LCP464-12 e IAC LCP515-20 são as que melhor se prestam a plantios adensados. As linhagens IAC LCP38817, IAC LCMP388-17-1 e IAC LCMP388-6, não são indicadas para essa finalidade em virtude de apresentarem maior diâmetro de copa. Todavia, quando se utiliza a variedade 'Mundo Novo' em plantios, deve-se levar em conta o excelente vigor desta variedade, utilizando-se distâncias mínimas de 2,0 a 2,5m entre linhas e 0,75 a 1,0 m entre plantas (Fazuoli, 1994).

\subsection{Podas}

\subsubsection{Morfologia do cafeeiro arábico}

A renovação dos ramos de cafeeiros a períodos regulares é baseada em características morfológicas. Em estado natural, o cafeeiro arábico é uma árvore compacta de até $10 \mathrm{~m}$ de altura. Possui um ramo central vertical dominante chamado de ortotrópico, de onde surgem ramos laterais chamados de plagiotrópicos que nascem em pares opostos. Esses primeiros ramos plagiotrópicos são chamados de ramos primários e surgem no ramo ortrotópico de uma gema que geralmente se apresenta sozinha (Fernie, 1966) e é comumente conhecida como "cabeça de série". Assim, se o ramo primário for cortado além do primeiro nó, não é possível haver rebrota (Warmer \& Gituanja, 1970).

Dos ramos primários, surgem os ramos secundários e destes, os ramos terciários, dos quais surgem os ramos quatemários (Gathaara, 1996).

Os ramos ortotrópicos, são oriundos de gemas presentes na axila foliar em uma série de 4 a 6 gemas (Rayner, 1946), abaixo da gema "cabeça de série".

As brotações de ramos ortotrópicos são similares a haste principal. Essa característica morfológica forma a base do ciclo regular de podas.

\subsubsection{Relação fonte-dreno}

As folhas, por possuirem capacidade fotossintetizante, constituem-se como fonte de fotossintetizados (carbohidratos). Órgãos armazenadores podem também, através de exportação para os drenos, funcionar como fontes. Já tecidos em crescimento, armazenando ou em metabolismo constituem-se drenos. Como exemplo, folhas jovens, frutos, ápices de raízes e 
ramos e os fotossintatos movimentam-se das fontes para os drenos, independentemente da gravidade (Salisbury \& Ross, 1978).

No cafeeiro, duas funções distintas ocorrem simultaneamente: a formação da produção e o crescimento vegetativo para o próximo periodo de produção. Assim, é necessária uma ação balanceadora da partição de fotossintetizados para ambas as funções (Gathaara, 1996).

Durante a frutificação e em anos de alta produção, ocorre uma drástica redução nas taxas de crescimento vegetativo, o que repercute em uma menor capacidade de produção do ano seguinte. Assim, o crescimento de plantas desprovidas de frutos, aumentaram a produção de pares de folhas e longitude dos eixos ortotrópicos e plagiotrópicos em relação às plantas com fruto em $43,8 \%, 100,1 \%, 42,3 \%$ e $129,5 \%$, respectivamente no período de um ano (Segura, 1994). Resultados semelhantes são mencionados por Carvalho (1985).

Em condições de habitat natural, altamente sombreado, a produção e crescimento da planta é escassa, sendo que a produção total de material seco de cafeeiros pode chegar a apenas 53\% em relação ao pleno sol (Jimenez \& Martinez, 1979). Estas características permitem manter uma relação equilibrada fruto: área foliar: raíz.

A adoção de cafeicultura intensiva, onde utilizam-se materiais genéticos de alto potencial produtivo e plantios a pleno sol, tem contribuído para induzir metabolicamente a planta, convertendo a frutificação em um forte dreno metabólico, às custas do crescimento da parte aérea e raízes.

Esta re-exportação energética produz um desequilíbrio e grandes quedas na capacidade de produção de biomassa. Isto ocorre em virtude do efeito de grande produção e baixo crescimento vegetativo serem alternados com anos de baixa frutificação e alto crescimento vegetativo (Cannel, 1985; Segura, 1989).

\subsubsection{Die-back}

Em geral, os cafeeiros cultivados intensamente apresentam a capacidade potencial de produzir colheitas abundantes nos primeiros anos de estabelecimento da lavoura. Ao longo dos anos, em maior ou menor grau, de acordo com o manejo e material genético utilizado, ocorre uma queda na produção seguida por lignificação progressiva. Esse fenômeno, conhecido por

"die back" ou "seca dos ponteiros", constitui-se em sintoma típico de depauperamento ou esgotamento que contribui para acentuar o ritmo bienal de produção (Rena et al., 1983).

São citadas várias causas para o problema: nutricional (Malavolta et al., 1958), patológica (Octávio, 1961; Mansk et al., 1975; Leguizamon \& Arcila, 1981), fisiológica-ambiental (Gopal \& Ramaiah, 1971; D'Souza, 1972; Figueiredo et al., 1980), ou ainda o conjunto destes (Clowes, 1973). Todavia, a elevada produção de frutos é uma característica que 
sistematicamente está associada com o fenômeno (Cannell, 1976; Kumar, 1979; Carvalho, 1985).

Como são necessários $20 \mathrm{~cm}^{2}$ de área foliar para atender as necessidades energéticas de cada fruto sem afetar o crescimento vegetativo da planta, em anos de alta produção, além da grande queda de frutos, pode ocorrer forte redução no crescimento e "seca de ponteiros" (Cannell, 1985). Essa "seca de ponteiros" pode ser evitada em plantas jovens, através da eliminação artificial das primeiras inflorescências (Cannell, 1974).

O esgotamento vegetativo do cafeeiro é, portanto, um fenômeno natural que pode ser acentuado por causas bióticas e pode ser minorado por meio de um bom manejo agronômico, tal como o rejuvenecimento dos tecidos, através de podas.

\subsubsection{Razões para adoção de podas}

As principais razões para se podar os cafeeiros são, segundo Fernie (1970):

1. Manter uma razão frutos: folha adequada.

2. Reduzir a bienuidade de produção

3. Regular o nível de produção

4. Auxiliar no controle de pragas

5. Auxiliar no controle de doenças

6. Diminuir o número de pulverizações

7. Possibilitar melhor incidência de luz e circulação de ar

8. Evitar a seca de ponteiros

\subsubsection{Tipos e sistemas de podas}

Os cafeeiros apresentam um fenômeno denominado de produção distal, ou seja, somente as seções de ramos plagiotrópicos diferenciadas no ciclo imediatamente anterior de crescimento se tornam produtivas, sendo que apenas $4 \%$ dos frutos são provenientes do ciclo de crescimento anterior ao último ciclo (Segura, 1994).

Atualmente, vários países produtores adotam diferentes tipos e sistemas de podas, que são descritos de forma detalhada em Henríquez (1983); Carvajal (1984); Melles \& Guimarães (1985); Willson (1985); Miguel et al., (1986); Hernandez (1988); Matiello (1991).

No Brasil, os principais tipos de poda adotados são a recepa, o decote e o esqueletamento (Thomaziello et al., 1996).

A recepa é um tipo de poda, procedendo-se o corte da planta próximo ao nível do solo $(40-60 \mathrm{~cm})$, constituindo-se uma poda drástica, onde são eliminados quase todo material 
vegetativo da planta e portanto, deve ser adotado apenas quando outras alternativas são inviáveis (Fernandes, 1983).

Quando ainda existem ramos com enfolhamento adequado na parte de baixo da planta (saia), o corte deve ser realizado um pouco mais alto, deixando-se esses ramos enfolhados, denominados ramos pulmão, que proporcionam um melhor desenvolvimento das rebrotas (Oficina Del Café, 1982) e é denominado "recepa com pulmão" (IBC, 1987).

$\mathrm{Na}$ poda do tipo decote é realizado o corte da planta a uma altura entre $1,5 \mathrm{~m}$ a $2,0 \mathrm{~m}$ com o objetivo de reduzir ou manter a altura das plantas para facilitar as práticas culturais, principalmente a colheita, bem como corrigir falhas, como o fenômeno denominado "pescoço pelado", onde há falta de ramos plagiotrópicos em um segmento do ramo principal, ocasionado por problemas nutricionais e climáticos (Miguel et al., 1986).

O esqueletamento, por sua vez é uma poda onde se procede o corte dos ramos primários a aproximadamente 20 a $25 \mathrm{~cm}$ da inserção com a haste principal (Tomaziello et al., 1996). Essa poda baseia-se na produção distal que o cafeeiro apresenta. Com isso, o diâmetro da copa dos cafeeiros é incrementado ano após ano e assim, decorrido alguns ciclos de produção, o diâmetro da copa atinge tal dimensão que dificulta os tratos culturais e a produção. Geralmente, esse tipo de poda é aplicada conjuntamente com o decote (Miguel et al., 1986).

Como no Brasil há geralmente a predominância de plantios largos (Miguel et al., 1986), é rara comum a adoção de um sistema de podas pré determinado. Normalmente a poda é baseada na inspeção do aspecto visual da lavoura. Com o aumento do número de plantios adensados dos últimos anos (FNP - Consultoria \& Comércio, 1996), tem-se buscado um sistema adequado de podas às condições brasileiras.

Costa ${ }^{1}$ adota um sistema de podas onde se procede o decote a $1,8 \mathrm{~m}$ associado a esqueletamento bienal. Com isso, a produção ocorre apenas a cada dois anos e, sendo mais concentrada, apresenta média igual ao sistema convencional (sem podas), porém com redução nos custos de produção e maximização do uso de infraestrutura.

Outra alternativa recomendada é a condução das plantas a livre crescimento e depois de 4 a 6 colheitas, quando o ciclo bienal se acentua e as dificuldades de colheita aumentam, diminuindo a eficiência de mão-de-obra, realiza-se a recepa por talhão (Androcioli Filho, 1994). Também pode-se adotar o sistema de poda por planta, onde a cada ano são podados por esqueletamento apenas os cafeeiros depauperados, de forma a manter sempre revigorada sua parte produtiva (Androcioli Filho, 1994).

\footnotetext{
${ }^{1}$ CosTA, T. E. da (Cia de cafés Bom Retiro). Comunicação pessoal, 1996.
} 
Um esquema de podas pré-determinado muito utilizado foi desenvolvido no Hawai por Beaumont \& Fukunaga (1958). Nesse sistema procede-se a recepa baixa de $20 \%$ da área a cada ano em esquema fixo para cada grupo de 5 ruas, sendo que são podadas anualmente em sequência, as ruas $2,4,1,3$ e 5, repetindo-se a sequência após completar-se o ciclo.

Em Java, o sistema Beaumont \& Fukunaga (1958) aumentou a produção em espaçamentos densos em relação a poda tradicional por decote para café robusta (Soenarjo, 1974). Também na África do Sul, Rooster (1976) encontrou melhores resultados com a adição de uma modificação do sistema Beaumont \& Fukunaga (1958) para ciclo de 3 anos em relação às podas tradicionalmente utilizadas.

Carvalho (1959) faz uma descrição do sistema Beaumont \& Fukunaga também com modificações para ciclos de 3 e 4 anos e menciona que o sistema foi adotado com sucesso na Costa Rica.

No Brasil, foram realizados alguns estudos onde se adotou o sistema Beaumont \& Fukunaga (1958). Toledo et al., (1993) afirma que para Catuaí em espaçamento de 1,75 × 1,0m, não há necessidade de podas até a $12^{\mathrm{a}}$ colheita quando comparou-se vários métodos de podas inclusive o Beaumont \& Fukunaga. No entanto, Toledo et al., (1987) em plantios adensados de 'Mundo Novo' e 'Catuai', encontraram melhores produções com 'Catuaí' em sistema Beaumont \& Fukunaga (1958) em relação a 'Mundo Novo'.

Além das podas, outra opção para se controlar os problemas adversos causados pelo fechamento das lavouras é a eliminação de ruas (Oliveira et al., 1990).

Com relação à altura de corte na recepa, Strauch \& Mestre (1972) não observaram efeito no crescimento das brotações quando adotou-se alturas de corte de 20,40 e $60 \mathrm{~cm}$. Já em El Salvador, Guerra (1972) concluiu que o corte a $60-90 \mathrm{~cm}$ de altura apresentou os melhores resultados na manutenção de brotações produtivas com 'Bourbon'.

Figueroa (1990) encontrou melhores produções quando se aplicou podas seletivas por planta do que em esquema Beaumont \& Fukunaga. Chegaram à mesma conclusão o Departamento de Investigaciones en Café (1980) e Soto (1980).

\subsection{6. Índice de área foliar e produtividade}

De modo geral, a taxa de produção de fotoassimilados aumenta em função do índice de área foliar (IAF), que expressa a quantidade de área foliar existente em uma superfície de terreno, até certos limites em virtude do auto sombreamento que as folhas da parte superior da planta exercem sobre as da parte inferior, reduzindo sensivelmente a capacidade produtiva das plantas (Bernardes, 1987). 
Para a variedade Caturra, as maiores produções estão relacionadas a um IAF entre 7,97 a 10 (Huerta \& Alvim, 1962; Valencia, 1973). Tal índice pode, por sua vez, ser atingido com densidade de plantio de 10.000 plantas por hectare com idade de 3 anos ou com 5.000 plantas por hectare com 4 anos ou mais procurando manter-se a lavoura nessas condições por meio de manejo de podas (Valencia, 1973).

No passado, os estudos realizados relacionavam altas produções e produtividades com densidades de plantio e espaçamentos, bem como tipos de formação da planta (Uribe \& Mestre, 1980; Siqueira et al., 1983; Siqueira et al., 1985; Uribe \& Mestre, 1988a; Uribe \& Mestre, 1988b; Miguel et al., 1986). Entretanto, não enfocam o manejo do tecido vegetativo por meio de tipos e sistemas de podas para garantir o máximo aproveitamento dos plantios adensados a curto e longo prazo.

Apesar disso, vários estudos com plantios adensados apresentavam melhores resultados com populações entre 5.000 e 10.000 plantas por hectare (Browning \& Fisher, 1976; Kumar, 1978; Cortes, 1985; Libran et al., 1985; Pavan et al., 1993). Coincidindo com as densidades de plantio que proporcionavam um IAF adequado encontradas por Huerta \& Alvim (1962).

Assim, um sistema de poda ideal, permitirá manter o IAF adequado à maximização da produtividade (Segura, 1994).

\subsubsection{Benefícios da poda na propriedade}

A adoção de podas apresenta ainda vários benefícios à propriedade. Através dela, os resíduos vegetais incorporados ao solo, aumentam o seu teor de matéria orgânica $e$ consequentemente as propriedades físico-químicas do solo são melhoradas, o que é particularmente importante em solos de baixa fertilidade (Pavan et al., 1993). Através da poda, podem ser incorporados ao solo entre 9,2 a 26 toneladas de material seco por hectare (Malavolta, 1990).

O material seco incorporado ao solo pode fornecer, segundo Malavolta (1990) até 312 $\mathrm{kg}$ de nitrogênio, $18 \mathrm{~kg}$ de fósforo e $284 \mathrm{~kg}$ de potássio, quantidades suficientes para satisfazer as necessidades da lavoura na maioria dos países produtores pelo ciclo seguinte de produção (Jayarama \& Ramaiah, 1988). Quando se utiliza cultivos intercalares de culturas anuais com o cafeeiro, geralmente há uma queda na produção de café (Chaves, 1978; Melles et al., 1985). No entanto, quando os cafeeiros são podados, há a possibilidade de se realizar cultivos intercalares, desde que devidamente adubados, sem prejudicar a produção de café vindoura (Chaves, 1978). 


\subsection{Densidades de plantio}

Segundo Romero \& Romero (1994), os primeiros plantios adensados no Brasil surgiram na década de 30 em Jacutinga, MG, objetivando a conservação do solo e, já na década de 40 é iniciado em Mococa um experimento com plantios adensados de café, porém não publicado. Desde então, vários trabalhos foram conduzidos objetivando estudar a relação entre a produção de café e o espaçamento adotado.

\subsubsection{Ajuste do espaçamento}

Os critérios que possibilitam ajustar as densidades de plantio, levando em conta os fatores que interferem no desenvolvimento da planta foram definidos apenas recentemente (Androcioli Filho \& Siqueira, 1993) podendo ser citados: altitude, variedade, nutrição das plantas, condições edafoclimáticas, nível tecnológico e capacidade de investimento (Androcioli Filho, 1994).

Como as formas de recomendação de espaçamento para café adotadas até recentemente não levavam em consideração os fatores mencionados, geralmente são indicados espaçamentos iguais para condições diferentes (Androcioli Filho, 1994).

Androcioli Filho \& Siqueira (1993) propõem uma fórmula matemática para determinação do espaçamento, onde a distância entre linhas é dada pela fórmula $E=D+L$, onde $E$ é 0 espaçamento entre as linhas em $m$; $D$ é o diâmetro da copa do cafeeiro adulto $(m)$ e $L$ é o espaço livre desejado pelo produtor para manejo da lavoura $(m)$.

As distâncias entre os cafeeiros é dada pela equação $E=D^{\star} 3,6^{-1}$ para uma planta por cova e $E=\left(D^{\star} 3,6^{-1}\right) \star 2$ para duas plantas por cova.

\subsubsection{Relação entre densidade de plantio e produtividade}

Carvajal (1981) afirma que altas densidades de plantio favorecem ao aumento da produção com variedades de porte baixo, sendo que espaçamentos de $0,84 \times 1,68 \mathrm{~m}$ são bastante comuns.

Altas densidades de plantio são recomendadas desde a década de 60 na Costa Rica (Ministério de Agricultura y Ganaderia, 1968).

No Brasil, o espaçamento a ser adotado depende do manejo futuro que se pretende aplicar, sendo utilizados plantios largos a livre crescimento com poda tardia ou plantios densos com podas regulares, a qual tem mostrado bons resultados (Carvajal, 1984). 
No Kenya, o espaçamento mais comumente utilizado é $2,75 \times 2,75 \mathrm{~m}$, tanto para pequenos como para grandes plantios (Mitchell, 1976d). Neste país, tais pesquisas sobre plantios adensados foram iniciadas em 1959 e os resultados publicados na década de 70 . Mitchell (1976 a, b, c, d) concluí que o espaçamento mais adequado é $1 \times 2 \mathrm{~m}$, correspondendo a uma população de 5000 plantas por hectare.

Em El Salvador, as densidades de plantio variam de 1587 plantas por hectare $(2,32 \times$ $2,32 \mathrm{~m})$ para a variedade Bourbon a 7143 plantas por hectare $(0,84 \times 1,68 \mathrm{~m})$ para a variedade Pacas (Instituto Salvadoreño de Investigaciones del Café, 1976).

$\mathrm{Na}$ Costa Rica, as variedades de porte alto como Mundo Novo são plantadas em densidades de 4570 plantas por hectare e as variedades de porte baixo, como Caturra em densidades de 6000 a 7143 plantas por hectare (Gutiérrez et al., 1975).

De modo geral, as melhores produções durante as duas a três primeiras colheitas são alcançadas em densidades de plantio superiores àquelas que apresentam maiores produções nos anos posteriores (Browning \& Fisher, 1976), possivelmente devido ao excessivo IAF.

A relação entre a colheita e a densidade de plantio, no primeiro ciclo de produção pode ser explicada pela equação sugerida por Holliday (1960):

$1 / y=a+b p+c p^{2}$

onde: $a, b$ e c são coeficientes cujos valores podem ser calculados de um conjunto de dados por regressão quadrática da relação entre a colheita por planta (y) e a densidade de plantio (p) (Browning \& Fisher, 1976).

Almeida et al., (1983) obtiveram médias de produção de café em espaçamentos de 2,0 $\times 0,5 \mathrm{~m}$, de até 2,5 vezes superior a produção do espaçamento tradicional $(4 \times 2,0 \mathrm{~m})$ no período de 5 safras. Resultados semelhantes foram obtidos por Miguel et al., (1983) e Toledo (1979).

Quando se deseja aumentar a densidade de plantio sem contudo comprometer a possibilidade de mecanização da lavoura, uma opção favorável é a redução do espaçamento entre covas na linha (Miguel et al., 1986). Siqueira et al., (1983) verificaram que em espaçamento $4 \times 1 \mathrm{~m}$, as produções foram até $23 \%$ superiores ao espaçamento $4 \times 2 \mathrm{~m}$ nas variedades Catuaí Vermelho, Acaiá e Icatú, no período de três colheitas. A mesma tendência pode ser observada em vários experimentos (Scaranari \& Nogueira Neto, 1963; Carvalho \& Souza, 1980; Siqueira et al., 1985; Pavan et al., 1994).

Além do aumento da produtividade com a diminuição do espaçamento, a distribuição dos cafeeiros na área também é importante. Lazzarini \& Moraes (1967) verificaram que espaçamentos, cujas distâncias na linha e entrelinha eram semelhantes, apresentavam maiores produtividades. Entretanto, Uribe \& Mestre (1958) não verificaram diferenças entre plantio com disposição em quadrado ou em retângulo na produção de quatro safras de café, enquanto 
Bocquet (1958) considera a disposição em triângulo equilátero a mais adequada para café robusta.

A redução nos espaçamentos proporcionou menores produções por cova (Salazar \& Mestre, 1977) diminuindo o ciclo bienal de produção (Carvalho \& Souza, 1980), permitindo uma recuperação mais rápida da lavoura após a ocorrência de geadas, uma veź que a intensidade dos danos será menor com a diminuição da produção por planta (Siqueira et al., 1985).

Experimentações realizadas no Estado de São Paulo, em 1932, indicaram resultados favoráveis às maiores densidades de plantio, com produção linear crescente até uma densidade de 5000 plantas por hectare (Scaranari, 1958; Scaranari \& Nogueira Neto, 1963). Kabaara (1969) menciona que um dos métodos para elevar a produção de café na América Central e Sul é o aumento do número de plantas por unidade de área.

Na Venezuela. Garcia et al., (1967) também cita a utilização de plantios mais densos como estratégia para o aumento da produção. Bellavita (1968) recomenda plantios com densidade de 5000 a 6666 plantas por hectare.

Hangdong \& Bartolome $(1963,1966)$, em ensaios com densidades de 1.111 e 3.333 plantas por hectare nas Filipinas, concluíram que os espaçamentos mais curtos foram mais produtivos.

Bosque et al., (1962) e Rodriguez et al., (1966) em ensaios com densidade de plantio de até 5.000 plantas por hectare em Porto Rico, obtiveram os melhores rendimentos com a densidade mais alta.

Na Colômbia, Uribe \& Mestre (1988b) em ensaios com densidades de plantio de até 20.000 plantas por hectare, verificaram na média de 4 colheitas, resposta quadrática da produção por área, concluindo ser a densidade de 14.740 plantas por hectare a mais produtiva. Os mesmos autores (1988a) já haviam concluído que densidades de 10.000 hastes por hectare, independente do sistema para obtê-los, constituía-se como adequada.

Em um período de cinco colheitas, Salazar \& Mestre (1977) concluem que a maior densidade de plantio é a mais produtiva em um ensaio com até 6.666 plantas por hectare. Os mesmos resultados foram encontrados por Uribe \& Salazar (1981) e Uribe \& Mestre (1980).

$\mathrm{Na}$ Costa do Marfim, Capot (1972) encontrou uma densidade ideal de plantio ao redor de 1.100 plantas por hectare para o híbrido "Arabusta", esperando-se que sejam realizadas podas a cada cinco anos.

$\mathrm{Na}$ Indonésia, por sua vez, Soenaryo \& Saelistyo (1976) em ensaio com várias densidades de plantio até 2.222 plantas por hectare, não verificaram diferenças na produção de café arábico por planta. Consequentemente, a produção por área foi incrementada com o aumento na densidade de plantio. 
Na Tailândia, Prasit \& Aksorn (1986) não observaram diferenças no desenvolvimento vegetativo de Caturra entre 5.000 e 2.500 plantas por hectare, exceto no tamanho dos internódios da haste principal.

O maior volume de pesquisas sobre a densidade de plantio em café, talvez tenha sido conduzido no Kenya, motivado por um Seminário sobre Intensificação da Cafeicultura realizado em 1968 (Mitchell, 1976), onde foram apresentados vários trabalhos cobrindo aspectos práticos e teóricos de várias técnicas (Huxley, 1968).

Browning \& Fisher (1976), encontraram melhores densidades de plantio para as duas primeiras colheitas ao redor de 5.000 a 10.000 plantas por hectare em espaçamentos progressivos, enquanto Gathaara \& Kiara (1990) encontraram relação linear positiva até 5.120 plantas por hectare, utilizando-se a variedade Catimor, resultado similar ao obtido com Caturra (Gathaara, 1988).

A concentração de plantas, aumentando-se o espaçamento e o número de plantas por cova, porém mantendo-se a densidade de plantio, não apresentou benefícios na produção de 'Caturra' e 'SL 28' com 10.000 plantas por hectare (Kiara, 1981).

Mwakha (1980) obteve as melhores produções de café em densidade de 10.000 plantas por hectare com a variedade 'SL 28 ' de porte baixo, mencionando que, em densidades superiores a 6.667 plantas por hectare, o plantio intercalar de feijão é prejudicado.

Gathaara (1988) verificou ainda, interação entre a densidade de plantio e a altitude local. Em altitude de $1.800 \mathrm{~m}$ sobre o nível do mar, Caturra apresentou os melhores resultados em 7.463 plantas por hectare, enquanto 'SL 28' em 3.322 plantas. Já em altitude de $1.600 \mathrm{~m}$ sobre o nivel do mar, ambas as variedades apresentaram melhor desempenho com 5.000 plantas por hectare e em altitude de $1.400 \mathrm{~m}$ sobre o nivel do mar, 'SL 28' apresentou ótima densidade de plantio com 5.000 plantas por hectare contra 7.463 plantas por hectare para 'Caturra'.

Njoroge \& Mwakha (1993), não detectaram diferenças na produção em densidades de 2.658 e 5.320 plantas por hectare no primeiro ciclo de produção, porém, foram superiores a 1.329 plantas por hectare, apresentando maior vegetação de lenho com 2.650 plantas por hectare.

Njoroge \& Kimemia (1994) também verificaram respostas diferenciadas à densidades de plantio em regiões úmidas com relação a regiões secas, mostrando incrementos na produção até 4.000 plantas por hectare. Contudo, em regiões secas, a produção cai em densidades acima desse patamar, enquanto em regiões úmidas a produção aumenta, porém em menor taxa.

No Brasil, a relação entre a população de cafeeiros por unidade de área e a produção, foi objeto de estudos de longo prazo no Estado de São Paulo (Lazzarini et al., 1967), onde 
concluíram que a densidade de $6 \mathrm{~m}^{2}$ por cova constituía-se como a mais produtiva. Todavia Scaranari \& Nogueira Neto (1963) verificaram melhores produções com densidades de 5.000 plantas por hectare. Santinato et al., (1994), verificaram produções crescentes em função do adensamento até $1 \mathrm{~m}$ entre ruas e até 0,5 a $0,75 \mathrm{~m}$ entre plantas na primeira safra. Siqueira \& Androcioli Filho (1994) também verificaram aumentos na produção com o adensamento nas primeiras colheitas, resultados semelhantes aos de Camargo et al., (1990); Toledo et al., (1990a, b); Toledo et al., (1989); Miguel et al., (1987).

Siqueira et al., (1985) recomenda o plantio de cafezais com espaçamentos de $2,5 \mathrm{~m}$ entre ruas e 1,7 a $2,0 \mathrm{~m}$ entre plantas com duas plantas por cova para as condições do Paraná, onde já havia sido demonstrado o potencial produtivo de plantios adensados (Siqueira et al., 1985), confirmado posteriormente por Pavan et al., (1994).

Diferentes variedades comportam-se diferentemente em função da densidade de plantio. Siqueira et al., (1990) verificaram produções mais elevadas de Acaiá em relação ao Icatu e Catuaí Vermelho nas quatro primeiras safras em plantios adensados. Contudo, após 11 colheitas, Icatu demonstrou incrementos lineares na produção até 14.286 plantas por hectare, enquanto Catuaí aumentou a produção até 7.143 plantas por hectare. Tal fato pode ser atribuído à característica de resistência à ferrugem na variedade.

Viana et al., (1984) observaram produções crescentes de Catuaí até a densidade máxima estudada de 7.812 plantas por hectare na média de sete safras.

\subsubsection{Fatores que afetam a produção em plantios adensados}

Gathaara \& Kiara (1984) estudaram os fatores que influenciam a produção em altas densidades de plantio de café e verificaram que o fluxo da radiação fotossinteticamente ativa através do dossel diminui exacerbadamente com o aumento da densidade de plantio. Aparentemente altera o parcionamento da matéria seca entre frutos e parte vegetativa, já que folhas de café apresentam fotossíntese líquida em intensidades de luz muito baixas (Kumar \& Tieszen, 1976). Enquanto isso, a iniciação de gemas florais requer intensidades de luz mais altas (Cannell, 1972).

OS autores não encontraram diferenças no potencial hídrico da folha como resposta à densidade de plantio. Resultados similares foram obtidos por Fisher \& Browning $(1978,1979)$. Provaveimente, porque o uso de água por unidade de área não é afetado pela densidade de plantio (Gathaara \& Kiara, 1984). Dessa forma, a água não é limitante à produção em plantios adensados, de forma mais acentuada que em plantios não adensados.

A umidade relativa no interior da lavoura tende a aumentar com o incremento na densidade de plantio, provavelmente devido ao dossel aerodinâmicamente mais suave dos 
plantios adensados (Huxley \& Cannell, 1968), Consequentemente, há uma diminuição na taxa de evapotranspiração em plantios com alta densidade.

O crescimento de ramos primários é maior no topo da planta em maiores densidades de plantio, enquanto na região mediana e na parte de baixo da planta, o comportamento é inverso. O mesmo ocorrendo com o número de frutos por nó (Gathaare \& Kiana, 1985).

O maior crescimento do topo da planta, provoca sombreamento e consequente diminuição no fluxo de luz ao longo do dossel (Gathaara \& Kiara, 1984), diminuindo com isso, os parâmetros que suportam a produção na parte de baixo do dossel em plantios adensados, já que menor número de gemas florais são iniciados sob sombra que quando bem iluminadas (Huxley \& Cannell, 1968; Wormer \& Gituanja, 1970; Cannell, 1972).

Práticas culturais que reduzem o número de nós produzidos e frutos por nó reduzem a produção final. Os nós produzidos constituem o componente de produção mais importante na resposta à variação da produção em função de práticas culturais (Cannell, 1973). Resultados semelhantes foram observados por Kuguru et al., (1978).

É importante lembrar que os aspectos acima mencionados reduzem a produção considerando-se apenas a planta, o que pode ser favorável em virtude de reduzir a bienalidade de produção (Carvalho \& Souza, 1980). Todavia a produtividade leva em consideração a densidade de plantio. Assim, apesar da menor produção por planta, a produção por área é incrementada com o adensamento.

\subsubsection{Influência da densidade de plantio nas condições do solo e uso de fertilizantes}

O aumento da densidade de plantio oferece maior proteção ao solo devido à maior cobertura proporcionada pelo próprio cafeeiro e pelo maior número de folhas que caem no chão, diminuindo a erosão, a temperatura do solo, a lixiviação e volatização, a evaporação da água, e intensifica a reciclagem de nutrientes, melhorando as propriedades físicas e químicas do solo, aumentando a estabilidade dos agregados, $\mathrm{pH}$, cálcio, magnésio e potássio, diminuindo o alumínio trocável (Siqueira et al., 1990; Pavan et al., 1991; Pavan et al., 1993).

Além disso, a manutenção da umidade nas camadas superficiais e a maior quantidade de raizes com melhor distribuição por volume de solo, contribuem para aumentar a eficiência de aproveitamento de nutrientes, quando se aumenta a densidade de plantio (Androcioli Filho, 1994).

Em Cuba, com o adensamento de 5.000 para 10.000 plantas por hectare constatou-se aumento da quantidade de raíz absorvente na área cultivada. $O$ aproveitamento pelos cafeeiros 
do nitrogênio total aplicado no solo elevou de $55 \%$ para $71 \%$ respectivamente da menor para a maior densidade (Rivera, 1993).

Em função da maior eficiência no uso de fertilizantes nos plantios adensados, devido à melhorias no solo e no sistema radicular, Pavan et al., (1990) verificaram produções superiores, na média, de nove colheitas, com populações de 6.667 plantas por hectare e dosagem mediana de fertilizantes químicos que em densidades de 3.333 e 2.222 plantas por hectare com altas dosagens de fertilizantes. Resultados semelhantes aos encontrados por Pavan et al., (1994). 


\section{MATERIAL E MÉTODOS}

Foram analisados e discutidos dois experimentos realizados pela Seção de Café do Instituto Agronômico (IAC), conduzidos no Centro Experimental de Campinas (latitude $22^{\circ} 54^{\prime} S$; longitude $47^{\circ} 05^{\prime} \mathrm{W}$; altitude $669 \mathrm{~m}$ ), em área de Latossolo Roxo, durante o período de janeiro de 1963 a dezembro de 1983.

O primeiro experimento recebeu a denominação de: "Ensaio de condução da planta $x$ Espaçamento x Número de pés por cova x Variedades".

O segundo experimento foi denominado: "Ensaio de condução da planta $x$ Espaçamento x Número de pés por cova na variedade 'Mundo Novo'".

\subsection{Experimento 1}

\subsubsection{Período de execução}

O experimento foi instalado em 18 de janeiro de 1965 e a primeira das 17 colheitas realizadas se deu em 02 de maio de 1967. O experimento se encerrou com a colheita de 15 de maio de 1983.

A abertura dos sulcos de plantio foi realizada em 14 de janeiro de 1963 e a adubação de plantio nos sulcos foi procedida no dia seguinte.

A variedade 'Caturra' foi semeada nos germinadores de areia em junho e a variedade 'Mundo Novo' em setembro de 1963. O transplante para os laminados se deu em outubro e novembro de 1963 respectivamente para 'Caturra' e 'Mundo Novo'.

\subsubsection{Tratamentos}

Os tratamentos foram constituidos de:

- Variedades: Caturra Amarelo e Mundo Novo LMP-376-4

- Para Caturra Amarelo, os seguintes espaçamentos:

$-1,62 m \times 0,62 m\left(1 m^{2}\right)-10.000$ covas. ha ${ }^{-1}$

$-2,00 m \times 1,00 m\left(2 m^{2}\right)-5.000$ covas.ha $^{-1}$

$-2,30 m \times 1,30 m\left(3 m^{2}\right)-3.333$ covas. ha ${ }^{-1}$ 
combinados com 1 ou 2 plantas por cova e conduzidos com sistema de podas proposto por Beaumont \& Fukunaga (1958) onde se procede a recepa baixa de $20 \%$ da área a cada ano em esquema fixo para cada grupo de 5 ruas, sendo podadas anualmente em sequência as ruas $2,4,1,3,5$.

$$
-2,79 \mathrm{~m} \times 1,79 \mathrm{~m}\left(5 \mathrm{~m}^{2}\right)-2.000 \text { covas.ha }{ }^{-1}
$$

com 2 plantas por cova e conduzido sem intervenção de podas.

- Para Mundo Novo, os seguintes espaçamentos:

$$
-2,3 m \times 1,3 m\left(3 m^{2}\right)-3.333 \text { covas.ha- }{ }^{-1}
$$

com 2 plantas por cova e conduzidos com sistema de podas tipo BEAUMONT \& FUKUNAGA.

$$
-3,0 m \times 2,0 m\left(6 m^{2}\right)-1.666 \text { covas.ha }{ }^{-1}
$$

com 2 plantas por cova e divididos em 2 sistemas de condução: sem poda e decotados a $2 \mathrm{~m}$ de altura após a $7^{\text {a }}$ colheita, sendo que os decotados sofriam desbrotas anuais nos meses de setembro e fevereiro para manutenção da altura das plantas, sendo portanto, eliminadas todas as brotações.

A Tabela 1 apresenta um resumo dos tratamentos:

Nos tratamentos que receberam duas plantas por cova, essas foram plantadas espaçadas $25 \mathrm{~cm}$ uma da outra.

O delineamento experimental foi em blocos ao acaso com 4 repetições.

As parcelas apresentavam bordadura simples e possuiam as seguintes dimensões úteis:

$6 \mathrm{~m}^{2}-5$ linhas de 4 covas $=120 \mathrm{~m}^{2}$

$5 \mathrm{~m}^{2}-6$ linhas de 5 covas $=150 \mathrm{~m}^{2}$

$3 \mathrm{~m}^{2}-7$ linhas de 6 covas $=126 \mathrm{~m}^{2}$

$2 \mathrm{~m}^{2}-7$ linhas de 8 covas $=112 \mathrm{~m}^{2}$

$1 \mathrm{~m}^{2}-7$ linhas de 12 covas $=84 \mathrm{~m}^{2}$

correspondendo a uma área total de $5.940 \mathrm{~m}^{2}(190,0 \times 66,0 \mathrm{~m})$ e útil de $4.640 \mathrm{~m}^{2}$

Tabela 1. Relação dos tratamentos do experimento 1.

\begin{tabular}{cccccc}
\hline TRAT. & VARIEDADE & ESPAÇAM. $(\mathrm{m})$ & DENSID. $\left(\mathrm{m}^{2} / \mathrm{cova}\right)$ & PL/CV & CONDUCÁO \\
\hline 1 & Caturra & $1,62 \times 0,62$ & 1 & 1 & Recepa BF \\
2 & Caturra & $2,00 \times 1,00$ & 2 & 1 & Recepa BF \\
3 & Caturra & $2,30 \times 1,30$ & 3 & 1 & Recepa BF \\
4 & Caturra & $1,62 \times 0,62$ & 1 & 2 & Recepa BF \\
5 & Caturra & $2,00 \times 1,00$ & 2 & 2 & Recepa BF \\
6 & Caturra & $2,30 \times 1,30$ & 3 & 2 & Recepa BF \\
7 & Caturra & $2,79 \times 1,79$ & 5 & 2 & Sem podas \\
8 & Mundo Novo & $2,30 \times 1,30$ & 3 & 2 & Recepa BF \\
9 & Mundo Novo & $3,00 \times 2,00$ & 6 & 2 & Decotado \\
10 & Mundo Novo & $3,00 \times 2,00$ & 6 & 2 & Sem podas \\
\hline
\end{tabular}

Recepa $\mathrm{BF}=$ recepa em esquema Beaumont \& Fukunaga. 


\subsubsection{Adubações}

Na Tabela 2 consta a adubação no sulco de plantio em g por metro de sulco:

Tabela 2. Quantidades de nutrientes (em g por metro de sulco) aplicados no plantio do experimento 1 .

\begin{tabular}{cccccc}
\hline Nutr. & $6 \mathrm{~m}^{2}$ & $5 \mathrm{~m}^{2}$ & $3 \mathrm{~m}^{2}$ & $2 \mathrm{~m}^{2}$ & $1 \mathrm{~m}^{2}$ \\
\hline $\mathrm{P}_{2} \mathrm{O}_{5}$ & 36 & 30 & 18 & 12 & 6 \\
$\mathrm{~K}_{2} \mathrm{O}$ & 36 & 30 & 18 & 12 & 6 \\
\hline
\end{tabular}

correspondendo às quantidades de $60 \mathrm{~kg}$.ha" de $\mathrm{P}_{2} \mathrm{O}_{5}$ e de $\mathrm{K}_{2} \mathrm{O}$, na forma de superfosfato simples e cloreto de potássio. Após o pegamento das mudas foram aplicados em cobertura a cada 45 dias, de janeiro a abril, $8 \mathrm{~g}$ de $\mathrm{N}$ por cova, tendo como fontes o nitrocálcio e o sulfato de amônio alternadamente.

Para o segundo e terceiro ano as adubações foram:

Tabela 3. Quantidades de nutrientes (em g.cova ${ }^{-1}$ ) aplicados no $2^{\circ}$ e $3^{\circ}$ ano após o plantio do experimento 1.

\begin{tabular}{ccc}
\hline Nutr. & $2^{\circ}$ ano & $3^{\circ}$ ano \\
\hline $\mathrm{N}$ & 54 & 108 \\
$\mathrm{P}_{2} \mathrm{O}_{5}$ & - & 5 \\
$\mathrm{~K}_{2} \mathrm{O}$ & 24 & 60 \\
\hline
\end{tabular}

divididos em 4 aplicações (Tabela 3) e, a partir do $4^{\circ}$ ano agrícola (adubação de produção), em g. cova $^{-1}$ (Tabela 4):

Tabela 4. Quantidades de nutrientes (em g.cova ${ }^{-1}$ ) aplicados como adubação de produção no experimento1.

\begin{tabular}{cccc}
\hline Esp. & $\mathrm{N}$ & $\mathrm{P}_{2} \mathrm{O}_{5}$ & $\mathrm{~K}_{2} \mathrm{O}$ \\
\hline $6 \mathrm{~m}^{2}$ & 228 & 48 & 144 \\
$5 \mathrm{~m}^{2}$ & 190 & 40 & 120 \\
$3 \mathrm{~m}^{2}$ & 114 & 24 & 72 \\
$2 \mathrm{~m}^{2}$ & 76 & 16 & 48 \\
$1 \mathrm{~m}^{2}$ & 38 & 8 & 24 \\
\hline
\end{tabular}

correspondendo a $380 \mathrm{~kg}$ de $\mathrm{N}, 80 \mathrm{~kg}$ de $\mathrm{P}_{2} \mathrm{O}_{5}$ e $240 \mathrm{~kg}$ de $\mathrm{K}_{2} \mathrm{O}$ por hectare na forma de nitrocálcio e sulfato de amonio $(\mathrm{N})$, alternadamente; superfosfato simples $\left(\mathrm{P}_{2} \mathrm{O}_{5}\right)$ e cloreto de 
potássio $\left(\mathrm{K}_{2} \mathrm{O}\right)$, aplicados em cobertura ao redor dos cafeeiros e debaixo da saia, em 4 a 5 vezes ao ano no período de outubro a abril.

Foram fornecidos micronutrientes boro e zinco através de pulverizações com 6 g.litro ${ }^{-1}$ de sulfato de zinco nos meses de novembro e fevereiro e de aplicações de Bórax na superfície do solo nas quantidades de $10 \mathrm{~g} \cdot \operatorname{cova}^{-1}$ no segundo ano agrícola e $20 \mathrm{~g} \cdot \mathrm{cova}^{-1}$ nos anos subsequentes.

\subsubsection{Condução das plantas}

As podas, em esquema Beaumont \& Fukunaga, começaram a ser adotadas logo após a segunda safra e o decote, após a sétima colheita.

\subsubsection{Parâmetros avaliados}

Foram medidas as produções de café beneficiado em kg.ha- ${ }^{-1}$, das 17 colheitas realizadas e estatísticamente analisadas, divididas em 5 grupos:

1) média do biênio inicial (duas primeiras colheitas) - 1967-1968;

2) média do primeiro ciclo de podas (5 safras - $3^{\mathrm{a}}$ à $7^{\mathrm{a}}$ colheita) - 1969-1973;

3) média do segundo ciclo de podas ( 5 safras - $8^{\text {a }}$ à $12^{\text {a }}$ colheita) - 1974-1978;

4) média do terceiro ciclo de podas ( 5 safras $-13^{a}$ à $17^{\underline{a}}$ colheita) $-1979-1983 \mathrm{e}$

5) média das 17 safras - 1967-1983.

Os dados de produção anual dos tratamentos são apresentados no Apêndice 1

\subsection{Experimento 2}

\subsubsection{Período de execução}

O experimento foi instalado em 20 de fevereiro de 1963 e a primeira das 12 colheitas realizadas ocorreu em 03 de maio de 1966. O experimento encerrou com a colheita de 08 de maio de 1977.

A abertura dos sulcos de plantio foi realizada em 19 de fevereiro de 1963 e no mesmo dia foi procedida a adubação de plantio nos sulcos.

A semeadura nos germinadores de areia foi feita em 15 de abril e o transplantio para os laminados se deu em 10 de julho de 1962, quando as mudas se encontravam no estágio de palito de fósforo.

\subsubsection{Tratamentos}

Foi utilizado no experimento a variedade 'Mundo Novo' MP376-4 e os tratamentos foram constituidos de: 
Espaçamentos:

$-2,0 \times 1,0 \mathrm{~m}\left(2,0 \mathrm{~m}^{2}\right.$ por cova $)-5.000$ covas. ha ${ }^{-1}$

$-2,5 \times 1,5 \mathrm{~m}\left(3,75 \mathrm{~m}^{2}\right.$ por cova $)-2.667$ covas. $^{-1} \mathrm{a}^{-1}$

$-3,0 \times 2,0 m\left(6,0 m^{2}\right.$ por cova) -1.667 covas. ha $^{-1}$

Para todos os espaçamentos foram plantadas com uma e duas plantas por cova. No caso dos tratamentos que receberam duas plantas por cova, a distância entre elas na coveta de plantio foi de $25 \mathrm{~cm}$.

Os espaçamentos $2,0 \times 1,0 \mathrm{~m}$ e $2,5 \times 1,5 \mathrm{~m}$ foram considerados como adensados enquanto o espaçamento $3,0 \times 2,0 \mathrm{~m}$ foi considerado largo (não adensado) para efeito de divisão dos sistemas de condução de podas.

Para os espaçamentos adensados houveram dois tipos de condução por podas:

- Sistema proposto por Beaumont \& Fukunaga (1958), procedendo-se a recepa baixa de $20 \%$ da área a cada ano em esquema fixo para cada grupo de cinco ruas, sendo podadas anualmente em sequência as ruas $2,4,1,3$ e 5.0 sistema de podas foi iniciado logo após a segunda colheita e foi realizado em dois ciclos (período 1968 a 1972 e 1973 a 1977).

- Recepa baixa de $50 \%$ da área aplicada uma única vez após a segunda colheita, sendo podadas ruas alternadas. Após a sétima colheita, a condução dada a essas parcelas foi a recepa baixa em $100 \%$ da área, aplicada uma única vez. Assim, nesse nivel do fator sistema de podas, o primeiro ciclo (período 1968 a 1972) recebeu recepa em $50 \%$ da área e no segundo ciclo (período 1973 a 1977), recebeu recepa em área total.

Para o espaçamento largo (não adensado), foram adotados os seguintes sistemas de condução:

- Sem podas ao londo do ciclo (Livre crescimento).

- Decotado a $2 \mathrm{~m}$ de altura após a sétima colheita e mantido com desbrotas permanentes nos meses de setembro e fevereiro para manutenção da altura das plantas, sendo portanto, eliminadas todas as brotações.

Logo, para o espaçamento largo houve condução a livre crescimento durante o biênio inicial e o primeiro ciclo (período 1968-1972), sendo o decote aplicado somente para o último ciclo (período 1973-1977).

A Tabela 5 apresenta um resumo dos tratamentos: 
Tabela 5. Relação dos tratamentos do experimento 2.

\begin{tabular}{ccccc}
\hline TRAT. & ESPAÇAM. $(\mathrm{m})$ & DENSID. $\left(\mathrm{m}^{2} \cdot\right.$ cova $\left.^{-1}\right)$ & PLCV & CONDUÇẢO \\
\hline 1 & $2,0 \times 1,0$ & 2,0 & 1 & Recepa BF \\
2 & $2,0 \times 1,0$ & 2,0 & 1 & Recepa baixa \\
3 & $2,0 \times 1,0$ & 2,0 & 2 & Recepa BF \\
4 & $2,0 \times 1,0$ & 2,0 & 2 & Recepa baixa \\
5 & $2,5 \times 1,5$ & 3,75 & 1 & Recepa BF \\
6 & $2,5 \times 1,5$ & 3,75 & 1 & Recepa baixa \\
7 & $2,5 \times 1,5$ & 3,75 & 2 & Recepa BF \\
8 & $2,5 \times 1,5$ & 3,75 & 2 & Recepa baixa \\
9 & $3,0 \times 2,0$ & 6,0 & 1 & Livre crescimento \\
10 & $3,0 \times 2,0$ & 6,0 & 1 & Decotado \\
11 & $3,0 \times 2,0$ & 6,0 & 2 & Livre crescimento \\
12 & $3,0 \times 2,0$ & 6,0 & 2 & Decotado \\
\hline
\end{tabular}

TRAT=tratamento; ESPAÇAM=espaçamento; DENSID=densidade de plantio; PL/CV=plantas por cova; Recepa BF=sistema de podas Beaumont \& Fukunaga; Recepa baixa=recepa $50 \%$ alternada no primeiro e recepa total no segundo ciclo. Variedade Mundo Novo MP376-4

O delineamento experimental foi em blocos ao acaso com duas repetições.

As parcelas apresentaram bordadura simples e possuiam as seguintes dimensões úteis:

$-2,0 \times 1,0 \mathrm{~m}-7$ linhas de 12 covas $=168 \mathrm{~m}^{2}$

$-2,5 \times 1,5 \mathrm{~m}-7$ linhas de 08 covas $=210 \mathrm{~m}^{2}$

$-3,0 \times 2,0 \mathrm{~m}-7$ linhas de 06 covas $=252 \mathrm{~m}^{2}$

Correspondendo a uma área total do experimento de $7.056 \mathrm{~m}^{2}(84,0 \times 84,0 \mathrm{~m})$ e útil de $5.040 \mathrm{~m}^{2}$.

\subsubsection{Adubações}

Na Tabela 6 consta a adubação no sulco de plantio em g por metro de sulco,

Tabela 6. Quantidades de nutrientes(em g por metro de sulco) aplicados no plantio do experimento 2.

\begin{tabular}{lccc}
\hline Nutr. & $2,0 \times 1,0$ & $2,5 \times 1,5$ & $3,0 \times 2,0$ \\
\hline$-\mathrm{P}_{2} \mathrm{O}_{5}$ & 13,34 & 25,00 & 40,00 \\
$-\mathrm{K}_{2} \mathrm{O}$ & 8,00 & 15,00 & 24,00 \\
\hline
\end{tabular}

correspondendo às quantidades de $67 \mathrm{~kg}$ de $\mathrm{P}_{2} \mathrm{O}_{5}$ e $40 \mathrm{~kg}$ de $\mathrm{K}_{2} \mathrm{O}$ por hectare na forma de superfosfato simples e cloreto de potássio. Após o pegamento das mudas fora aplicados em cobertura a cada 45 dias no período de janeiro a abril $8 \mathrm{~g}$ de $\mathrm{N}$ por cova, tendo como fontes o nitrocálcio e sulfato de amônio alternadamente. 
Para o segundo e terceiro ano as adubações foram em g.cova ${ }^{-1}$, conforme a Tabela 7 , divididas em 5 aplicações no período de outubro a abril.

Tabela 7. Quantidades de nutrientes (em g por cova) aplicados no segundo e terceiro ano após o plantio do experimento 2.

\begin{tabular}{lcc}
\hline Nutr. & $2^{\circ}$ ano & $3^{\circ}$ ano \\
\hline $\mathrm{N}$ & 57,5 & 135 \\
$\mathrm{P}_{2} \mathrm{O}_{5}$ & -- & 25 \\
$\mathrm{~K}_{2} \mathrm{O}$ & 30 & 75 \\
\hline
\end{tabular}

A partir do $4^{\circ}$ ano agrícola (adubação de produção), foram aplicadas as seguintes quantidades de nutrientes em g.cova ${ }^{-1}$, conforme a Tabela 8 ,

Tabela 8. Quantidades de nutrientes (em g por cova) aplicados como em adubação de produção no experimento 2.

\begin{tabular}{rlcr}
\hline Esp. & $\mathrm{N}$ & $\mathrm{P}_{2} \mathrm{O}_{5}$ & $\mathrm{~K}_{2} \mathrm{O}$ \\
\hline $3,0 \times 2,0$ & 227 & 48 & 144 \\
$2,5 \times 1,5$ & 142 & 30 & 90 \\
$2,0 \times 1,0$ & 76 & 16 & 48 \\
\hline
\end{tabular}

correspondendo a $380 \mathrm{~kg}$ de $\mathrm{N} ; 80 \mathrm{~kg}$ de $\mathrm{P}_{2} \mathrm{O}_{5}$ e $240 \mathrm{~kg}$ de $\mathrm{K}_{2} \mathrm{O}$ por hectare na forma de nitrocálcio e sulfato de amônio $(\mathrm{N})$, alternadamente; superfosfato simples $\left(\mathrm{P}_{2} \mathrm{O}_{5}\right)$ e cloreto de potássio $\left(\mathrm{K}_{2} \mathrm{O}\right)$, aplicados em cobertura, ao redor do cafeeiro e debaixo da saia, em 4 a 5 vezes ao ano, no período de outubro a abril.

Foram fornecidos os micronutrientes boro e zinco através de pulverizações com 6 g.litro ${ }^{-1}$ de sulfato de zinco nos meses de novembro e fevereiro e de aplicações de borax, na superficie do solo nas quantidades de $10 \mathrm{~g} \cdot \mathrm{cova}^{-1}$ no segundo ano agrícola e $20 \mathrm{~g} \mathrm{cova}^{-1}$ nos anos subsequentes.

\subsubsection{Condução das plantas}

Após a segunda colheita foram feitas podas em esquema Beaumont \& Fukunaga e a recepa de $50 \%$ das plantas em ruas alternadas.

Após a sétima colheita foi iniciado o segundo ciclo de podas em esquema Beaumont \& Fukunaga; efetuou-se a poda tipo decote nos tratamentos correspondentes. Nos tratamentos que tiveram ruas alternadas recepadas após a segunda colheita, foi feita a recepa baixa de todas as plantas. 


\subsubsection{Parâmetros avaliados}

Foram medidas as produções de café beneficiado, em kg.ha ${ }^{-1}$, das 12 colheitas realizadas e estatisticamente analisadas, divididas em 3 grupos:

1) média do biênio inicial (duas primeiras colheitas) - 1966-1967;

2) média do primeiro ciclo de podas (5 safras $-3^{\text {a }}$ à $7^{\underline{a}}$ colheita) $-1968-1972 \mathrm{e}$

3) média do segundo ciclo de podas (5 safras - $8^{\text {à }} 12^{\underline{a}}$ colheita) - 1973-1977.

Os dados de produção anual dos tratamentos são apresentados no Apêndice 2

\subsection{Análises estatísticas}

As análises estatísticas foram realizadas seguindo procedimentos descritos em Pimentel Gomes (1987) e em Campos (1984).

Os parâmetros estimadores da regressão linear do experimento 1, foram calculados pelo método dos polinômios ortogonais, tendo em vista que os níveis do fator densidade de plantio eram igualmente espaçados.

No experimento 2, como os níveis do fator densidade de plantio (espaçamento) não eram igualmente espaçados, os parâmetros estimadores da regressão linear foram calculados pelo método dos quadrados mínimos. 


\section{RESULTADOS E DISCUSSÃO}

\subsection{Experimento 1}

\subsubsection{Biênio inicial}

Na Tabela 9 é apresentada a análise de variância para os fatores estudados. As produções médias dos tratamentos, em $\mathrm{kg} \mathrm{ha}^{-1}$ de café beneficiado, são apresentadas na Tabela 10 e resumido, as médias dos fatores principais nas Tabelas 11 e 12 .

Verifica-se, pela Tabela 9 que o contraste entre as variedades 'Caturra' e 'Mundo Novo' foi significativo e que, as médias apresentadas na Tabela 11, mostram uma produção mais elevada para 'Caturra' que 'Mundo Novo'. Essa produção mais elevada da variedade 'Caturra' se deve às densidades de plantio maiores que as da variedade 'Mundo Novo', à fase jovem dos cafeeiros, a ausência de concorrência entre plantas nos espaçamentos mais adensados, e consequentemente dos diversos problemas ligados ao fechamento das lavouras.

Considerando-se a variedade 'Caturra', há significância para todos os contrastes estudados. A densidade de plantio que propiciava $5 \mathrm{~m}^{2}$ por cova (não adensado), apresentou uma produção de aproximadamente metade da média dos espaçamentos que correspondiam áreas de 3,0;2,0 e 1,0 $\mathrm{m}^{2}$ por cova, conforme demonstra a Tabela 11.

Entre os espaçamentos adensados para 'Caturra', formou-se um fatorial $3 \times 2$ entre o fator espaçamento nos niveis de 3,$0 ; 2,0$ e $1,0 \mathrm{~m}^{2}$ por cova combinados com os níveis de 1 e 2 do número de plantas por cova.

Dentre esses fatores, o espaçamento foi significativo tanto para tendência linear quanto quadrática. No entanto, o coeficiente de determinação $\left(r^{2}\right)$ de regressão linear, igual a 0,98 , permitiu optar por esse modelo de regressão para explicar a tendência da produção em relação à densidade de plantio.

A equação de regressão assim determinada permitiu plotar a Figura 1, onde é apresentado o grande decréscimo de produção com o aumento da área ocupada por cova, evidenciando a falta de competição entre as plantas.

O número de plantas por cova também mostrou-se significativa, bem como a interação entre o espaçamento e o número de plantas por cova. O desdobramento dos niveis de plantas por cova dentro dos espaçamentos é apresentado na Tabela 13, mostrando significância para o 
fator nos níveis de 1,0 e $2,0 \mathrm{~m}^{2}$ por cova e as médias relativas podem ser conferidas nas Tabelas 10 e 12, onde verifica-se que a adoção de duas é superior a uma planta por cova. No entanto, apesar de a densidade de plantio com $1 \mathrm{~m}^{2}$ por cova com uma planta ter o mesmo número de plantas por área que a densidade de plantio com $2 \mathrm{~m}^{2}$ por cova com duas plantas, a sua produção é consideravelmente superior, mostrando que, para uma mesma população de plantas por área, a distribuição mais uniforme, uma planta por cova, é mais adequada.

$\mathrm{Na}$ variedade 'Mundo Novo' comparando-se o adensamento $\left(3 \mathrm{~m}^{2}\right.$ por cova) com o espaçamento convencional $\left(6 \mathrm{~m}^{2}\right.$ por cova) verifica-se pela Tabela 17 que há significância e, pela Tabela 11 que a produção no adensado foi aproximadamente $80 \%$ superior à produção do espaçamento convencional.

Considerando-se a grande superioridade de produção dos espaçamentos adensados sobre os espaçamentos tradicionais, tanto para 'Caturra' quanto para 'Mundo Novo' mostrado nas Tabelas 10 e 11, fica evidente a viabilidade produtiva nas duas primeiras colheitas dos plantios adensados em relação aos tradicionais, devido à falta de concorrência entre as plantas quando jovens.

Tabela 9: Análise da variância do experimento 1 - Biênio inicial (1967-1968).

\begin{tabular}{|c|c|c|c|c|}
\hline Fonte de variação & GL & SQ & QM & $\mathbf{F}$ \\
\hline Bloco & 3 & 652584 & 217528 & \\
\hline (Tratamento) & (9) & (2267631) & $(251959)$ & $(4,97) *$ \\
\hline Mundo Novo vs Caturra & 1 & 1576147 & 1576147 & $31,07 *$ \\
\hline (dentro de Caturra) & (6) & (18909114) & (3151519) & $(62,13)$ * \\
\hline $5 \mathrm{~m}^{2}$ vs $\left[3,2,1 \mathrm{~m}^{2}\right]$ & 1 & 3608588 & 3608588 & 71,14 * \\
\hline (dentro de $3,2,1 \mathrm{~m}^{2}$ ) & (5) & (15299925) & (3059985) & $(60,32)$ * \\
\hline (Espaçamento) & (2) & (13395194) & (6697597) & $(132,03)$ * \\
\hline comp. Linear & 1 & 13104400 & 13104400 & 258,33 * \\
\hline comp. Quadrático & 1 & 290785 & 290785 & 5,73 * \\
\hline Plantas por Cova & 1 & 1505004 & 1505004 & 29,67 * \\
\hline Espaçam. x PI. por cova & 2 & 399736 & 199868 & 3,94 * \\
\hline (dentro de Mundo Novo) & (2) & (2191672) & $(1095836)$ & $(21,60)$ * \\
\hline $6 \mathrm{~m}^{2}$ vs $3 \mathrm{~m}^{2}$ & 1 & 2170248 & 2170248 & 42,78 * \\
\hline desvios & 1 & 21424 & 21424 & 0,42 \\
\hline Resíduo & 27 & 1369629 & 50727 & \\
\hline Total & 39 & 4289844 & & \\
\hline $\begin{array}{l}\text { Média geral }=1.736,20 \\
C V(\%)=12,9\end{array}$ & & & & \\
\hline
\end{tabular}


Tabela 10: Médias de produção dos tratamentos do experimento 1, em kg.ha $a^{-1}$ de café beneficiado - Biênio inicial (1967-1968).

\begin{tabular}{lccr}
\hline Variedade & Plantas por cova & Espaçamento & \multicolumn{1}{c}{ Médias } \\
\hline Mundo Novo & 2 Plantas/cova & $3,0 \times 2,0 \mathrm{~m}$ & 1131 \\
& & $2,30 \times 1,30 \mathrm{~m}$ & 2031 \\
Caturra & 2 Plantas/cova & $2,79 \times 1,79 \mathrm{~m}$ & 987 \\
& & $2,30 \times 1,30 \mathrm{~m}$ & 1254 \\
& & $2,0 \times 1,0 \mathrm{~m}$ & 2189 \\
& & $1,62 \times 0,62 \mathrm{~m}$ & 3347 \\
& 1 Plantas/cova & $2,30 \times 1,30 \mathrm{~m}$ & 1118 \\
& & $2,0 \times 1,0 \mathrm{~m}$ & 1526 \\
& & $1,62 \times 0,62 \mathrm{~m}$ & 2645 \\
\hline
\end{tabular}

Tabela 11: Médias de produção das variedades estudadas no experimento 1 , em kg.ha- ${ }^{-1}$ de café beneficiado - Biênio inicial (1967-1968).

\begin{tabular}{lccc} 
& \multicolumn{2}{c}{ Sistema de plantio } & \\
\cline { 2 - 3 } Variedade & Não adensado & Adensado & Média \\
\hline Mundo Novo & $1.131(2)$ & $2.031(1)$ & $1.430(3)$ \\
Caturra & $987(1)$ & $2.013(6)$ & $1.866(7)$ \\
\hline
\end{tabular}

Entre parênteses está representado o número de tratamentos que compõem a média.

Tabela 12: Médias de produção nos espaçamentos e número de plantas por cova estudados com a variedade Caturra no experimento 1 , em $\mathrm{kg}^{-h a^{-1}}$ de café beneficiado - Biênio inicial (1967-1968).

\begin{tabular}{ccccc}
\hline & \multicolumn{3}{c}{ Área por cova } & \\
\cline { 2 - 5 } PI. por cova & $2,30 \times 1,30 \mathrm{~m}$ & $\mathbf{2 , 0} \times 1,0 \mathrm{~m}$ & $\mathbf{1 , 6 2 \times 0 , 6 2 \mathrm { m }}$ & Média \\
\hline 1 & 1.118 & 1.526 & 2.645 & 1.763 \\
2 & 1.254 & 2.189 & 3.347 & 2.263 \\
Média & 1.186 & 1.857 & 2.996 & \\
\hline
\end{tabular}


Tabela 13: Análise da variância do desdobramento da interação Espaçamento $x$ Plantas/cova do experimento 1 - Biênio inicial (1967-1968).

\begin{tabular}{|c|c|c|c|c|c|}
\hline Fonte de variação & $\mathbf{G L}$ & SQ & QM & $\mathbf{F}$ & \\
\hline Bloco & 3 & 652584 & 217528 & & \\
\hline (Tratamento) & (9) & $(2267631)$ & $(251959)$ & $(4,97)$ & ** \\
\hline Mundo Novo vs Caturra & 1 & 1576147 & 1576147 & 31,07 & ** \\
\hline (dentro de Caturra) & (6) & (18909114) & $(3151519)$ & $(62,13)$ & 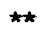 \\
\hline $5 \mathrm{~m}^{2}$ vs $\left[3,2,1 \mathrm{~m}^{2}\right]$ & 1 & 3608588 & 3608588 & 71,14 & ** \\
\hline (dentro de $3,2,1 \mathrm{~m}^{2}$ ) & (5) & (15299925) & (3059985) & $(60,32)$ & 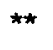 \\
\hline Espaçamento & 2 & 13395194 & 6697597 & 132,03 & ** \\
\hline $\begin{array}{l}\text { PI./cova dentro de espaça- } \\
\text { mento } 3 \mathrm{~m}^{2} \\
\text { PI./cova dentro de espaca- }\end{array}$ & 1 & 37264 & 37264 & 0,73 & \\
\hline $\begin{array}{l}\text { mento } 2 \mathrm{~m}^{2} \\
\mathrm{PI} / \text { cova dentro de espaça- }\end{array}$ & 1 & 880464 & 880464 & 17,36 & ** \\
\hline mento $1 \mathrm{~m}^{2}$ & 1 & 987012 & 987012 & 19,46 & *夫 \\
\hline (dentro de Mundo Novo) & (2) & (2191672) & (1095836) & $(21,60)$ & ** \\
\hline $6 \mathrm{~m} 2 \mathrm{vs} 3 \mathrm{~m} 2$ & 1 & 2170248 & 2170248 & 42,78 & ** \\
\hline desvios & 1 & 21424 & 21424 & 0,42 & \\
\hline Resíduo & 27 & 1369629 & 50727 & & \\
\hline Total & 39 & 4289844 & & & \\
\hline
\end{tabular}

** - significativo pelo teste $\mathrm{F}$ ao nivel de $1 \%$.

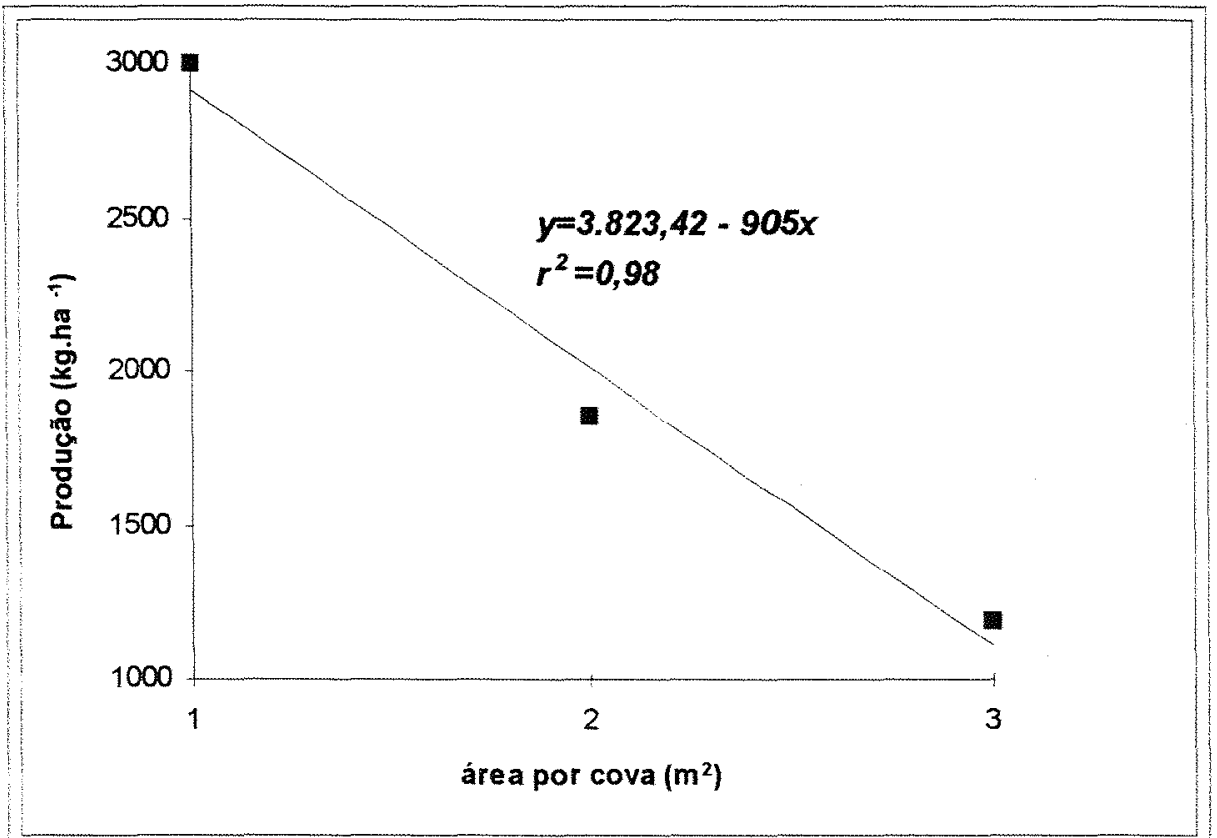

Figura 1: Gráfico da regressão linear entre a produção de café beneficiado da variedade Caturra, em kg.ha ${ }^{-1}$, e área por cova do biênio inicial (19671968) no experimento 1 


\subsubsection{Primeiro ciclo de podas}

Após a segunda safra, os espaçamentos adensados para 'Caturra', começaram a sofrer interferência por podas programadas em esquema "Beaumont \& Fukunaga", pré-determinado.

A Tabela 14 apresenta a análise de variância para os contrastes estudados. Dentre esses contrastes, verifica-se que a significância na comparação entre 'Caturra' e 'Mundo Novo' e as médias são apresentadas nas Tabelas 15 e 16.

Os resultados desse período mostram uma inversão no comportamento das variedades, já que a produção de 'Mundo Novo' foi $66 \%$ superior a 'Caturra', que apresentou pronunciada queda de produção em relação ao biênio inicial, conforme as Tabelas 11 e 12.

Considerando-se a variedade 'Caturra', a comparação entre o espaçamento tradicional $\left(5 \mathrm{~m}^{2}\right.$ por cova) e os espaçamentos adensados $\left(3,0,2,0\right.$ e $1,0 \mathrm{~m}^{2}$ por cova) foi significativa, conforme Tabela 14. Neste caso, os adensados apresentaram uma média de produção superior ao tradicional, como pode ser observado na Tabela 16. No entanto, a diferença de produção foi bem menos acentuada que no biênio inicial.

As médias de produção do espaçamento tradicional apresentou pequena variação entre o biênio inicial e o primeiro ciclo. Ao contrário, houve queda pronunciada na produção dos espaçamentos adensados entre os dois períodos, podendo-se atribuir tal fato ao esquema de podas programadas.

Assim, a concorrência entre as covas ainda não havia se iniciado de forma pronunciada e a produção foi depreciada em função da inexistência de $20 \%$ da área produtiva, devido à recepa, e ao gradiente do crescimento das plantas em função da programação das podas.

Considerando-se o fatorial formado nos espaçamentos adensados para 'Caturra', verifica-se, pela Tabela 14 que a tendência linear é a que melhor explica o comportamento da produção como resposta ao espaçamento.

Na Figura 2 são plotados os resultados da análise de regressão realizada. Por ele, verifica-se ainda uma queda na produção em função do aumento da área por cova. Todavia, a queda de produção é bem menos pronunciada que no biênio inicial, conforme mostram as Tabelas 12 e 17 . No biênio inicial a produção com densidade de $1 \mathrm{~m}^{2}$ por cova foi de $2.996 \mathrm{~kg}$ de café beneficiado por hectare, enquanto na densidade de $3 \mathrm{~m}^{2}$ por cova, a produção foi de $1.186 \mathrm{~kg}$ de café beneficiado por hectare, logo $150 \%$ maior. Já no primeiro ciclo de podas as produções de $1.339 \mathrm{~kg}$ de café beneficiado por hectare em $1 \mathrm{~m}^{2}$ por cova contra $1.000 \mathrm{~kg}$ de café beneficiado por hectare em $3 \mathrm{~m}^{2}$ por cova, correspondem a uma diferença de $33,9 \%$.

O número de plantas por cova, assim como a interação entre o espaçamento e o número de plantas por cova, não foi significativo (Tabela 14). As médias de produção podem ser conferidas nas Tabelas 15 e 17. 
Tal fato, mostra o início da concorrência por fatores de produção entre as plantas na cova. Com duas plantas na cova a produção não diferencia significativamente da produção obtida com uma planta por cova, em virtude da competição entre as plantas e consequente redução individual da produção. Contudo, apesar da existência de duas plantas na cova, a produção se manteve semelhante.

Desta forma, a utilização de duas plantas por cova mostrou-se ineficiente para plantios adensados com a variedade Caturra, já no primeiro ciclo de podas.

Com a variedade Mundo Novo, não houve diferenças significativas entre 0 espaçamento adensado e o espaçamento tradicional, conforme médias de produção apresentadas na Tabela 16.

Como a variedade Mundo Novo é mais vigorosa, de porte alto, a concorrência entre as plantas no espaçamento adensado se inicia mais cedo que na variedade 'Caturra', diminuindo a produção, apesar das podas programadas.

Tabela 14: Análise da variância do experimento 1 - Primeiro ciclo de podas (1969-1973).

\begin{tabular}{|c|c|c|c|c|c|}
\hline Fonte de variação & $\mathbf{G L}$ & SQ & QM & $\mathbf{F}$ & \\
\hline Bloco & 3 & 138900 & 46300 & & \\
\hline (Tratamento) & (9) & $(5559183)$ & $(617687)$ & $(40,84)$ & )$\star \star$ \\
\hline $\begin{array}{l}\text { Mundo Novo vs Caturra } \\
\text { (dentro de Caturra) }\end{array}$ & $\begin{array}{c}1 \\
(6)\end{array}$ & $\begin{array}{l}4801507 \\
(708300)\end{array}$ & $\begin{array}{l}4801507 \\
(118050)\end{array}$ & $\begin{array}{r}317,46 \\
(7,80)\end{array}$ & $6 *$ \\
\hline $5 \mathrm{~m}^{2}$ vs $\left[3,2,1 \mathrm{~m}^{2}\right]$ & 1 & 156022 & 156022 & 10,32 & $2 * *$ \\
\hline (dentro de $3,2,1 \mathrm{~m}^{2}$ ) & (5) & $(529420)$ & $(105884)$ & $(7,00)$ & ) $* *$ \\
\hline (Espaçamento) & (2) & $(466860)$ & $(233430)$ & $(15,43)$ & ** \\
\hline comp. Linear & 1 & 459684 & 459684 & 30,39 & $9^{\star \star}$ \\
\hline comp. Quadrático & 1 & 7176 & 7176 & 0,47 & \\
\hline Plantas por Cova & 1 & 5104 & 5104 & 0,34 & \\
\hline Espaçam. X PI. por cova & 2 & 57426 & 28713 & 1,90 & \\
\hline (dentro de Mundo Novo) & (2) & (49378) & (24689) & $(1,63)$ & \\
\hline $6 \mathrm{~m}^{2}$ vs $3 \mathrm{~m}^{2}$ & 1 & 80 & 80 & 0,01 & \\
\hline desvios & 1 & 49298 & 49298 & 3,26 & \\
\hline Residuo & 27 & 408375 & 15125 & & \\
\hline Total & 39 & 6106458 & & & \\
\hline $\begin{array}{l}\text { Média geral }=1.075,4 \\
C V(\%)=11,4\end{array}$ & & & & & \\
\hline
\end{tabular}


Tabela 15: Médias de produção dos tratamentos do experimento $1 \mathrm{em} \mathrm{kg.ha-1}$ de café beneficiado - Primeiro ciclo de podas (1969-1973).

\begin{tabular}{|c|c|c|c|c|}
\hline Variedade & Plantas por cova & Espaçamento & Sistema de Podas & Médias \\
\hline Mundo Novo & 2 Plantas/cova & $\begin{array}{c}3,0 \times 2,0 \mathrm{~m} \\
2,30 \times 1,30 \mathrm{~m}\end{array}$ & $\begin{array}{l}\text { Livre Crescimento } \\
\text { Recepa BF }\end{array}$ & $\begin{array}{l}1904 \\
1909\end{array}$ \\
\hline Caturra & $\begin{array}{l}2 \text { Plantas/cova } \\
1 \text { Plantas/cova }\end{array}$ & $\begin{array}{c}2,79 \times 1,79 \mathrm{~m} \\
2,30 \times 1,30 \mathrm{~m} \\
2,0 \times 1,0 \mathrm{~m} \\
1,62 \times 0,62 \mathrm{~m} \\
2,30 \times 1,30 \mathrm{~m} \\
2,0 \times 1,0 \mathrm{~m} \\
1,62 \times 0,62 \mathrm{~m}\end{array}$ & $\begin{array}{l}\text { Livre Crescimento } \\
\text { Recepa BF } \\
\text { Recepa BF } \\
\text { Recepa BF } \\
\text { Recepa BF } \\
\text { Recepa BF } \\
\text { Recepa BF }\end{array}$ & $\begin{array}{r}954 \\
1071 \\
1229 \\
1290 \\
929 \\
1186 \\
1387\end{array}$ \\
\hline
\end{tabular}

Tabela 16: Médias de produção das variedades estudadas no experimento $1 \mathrm{em}$ kg.ha ${ }^{-1}$ de café beneficiado - Primeiro ciclo de podas (1969-1973).

\begin{tabular}{lccc}
\hline & \multicolumn{3}{c}{ Sistema de plantio } \\
\cline { 2 - 4 } Variedade & Não adens. (LC) & Adensado (BF) & Média \\
\hline Mundo Novo & $1.904(2)$ & $1.909(1)$ & $1.905(3)$ \\
Caturra & $954(1)$ & $1.182(6)$ & $1.149(7)$ \\
\hline
\end{tabular}

Entre parênteses está representado o número de tratamentos que compõem a média.

Tabela 17: Médias de produção dos espaçamentos e número de plantas por cova estudados, com a variedade Caturra, no experimento 1 , em kg.ha ${ }^{-1}$ de café beneficiado - Primeiro ciclo de podas (1969-1973).

\begin{tabular}{ccccc} 
& \multicolumn{3}{c}{ Área por cova } & \\
\cline { 2 - 4 } Pl. por cova & $\mathbf{2 , 3 0 \times 1 , 3 0 ~} \mathbf{m}$ & $\mathbf{2 , 0 \times 1 , 0 ~} \mathbf{m}$ & $\mathbf{1 , 6 2 \times 0 , 6 2} \mathbf{m}$ & Média \\
\hline 1 & 929 & 1.186 & 1.387 & 1.167 \\
2 & 1.071 & 1.229 & 1.290 & 1.197 \\
Média & 1.000 & 1.208 & 1.339 & \\
\hline
\end{tabular}




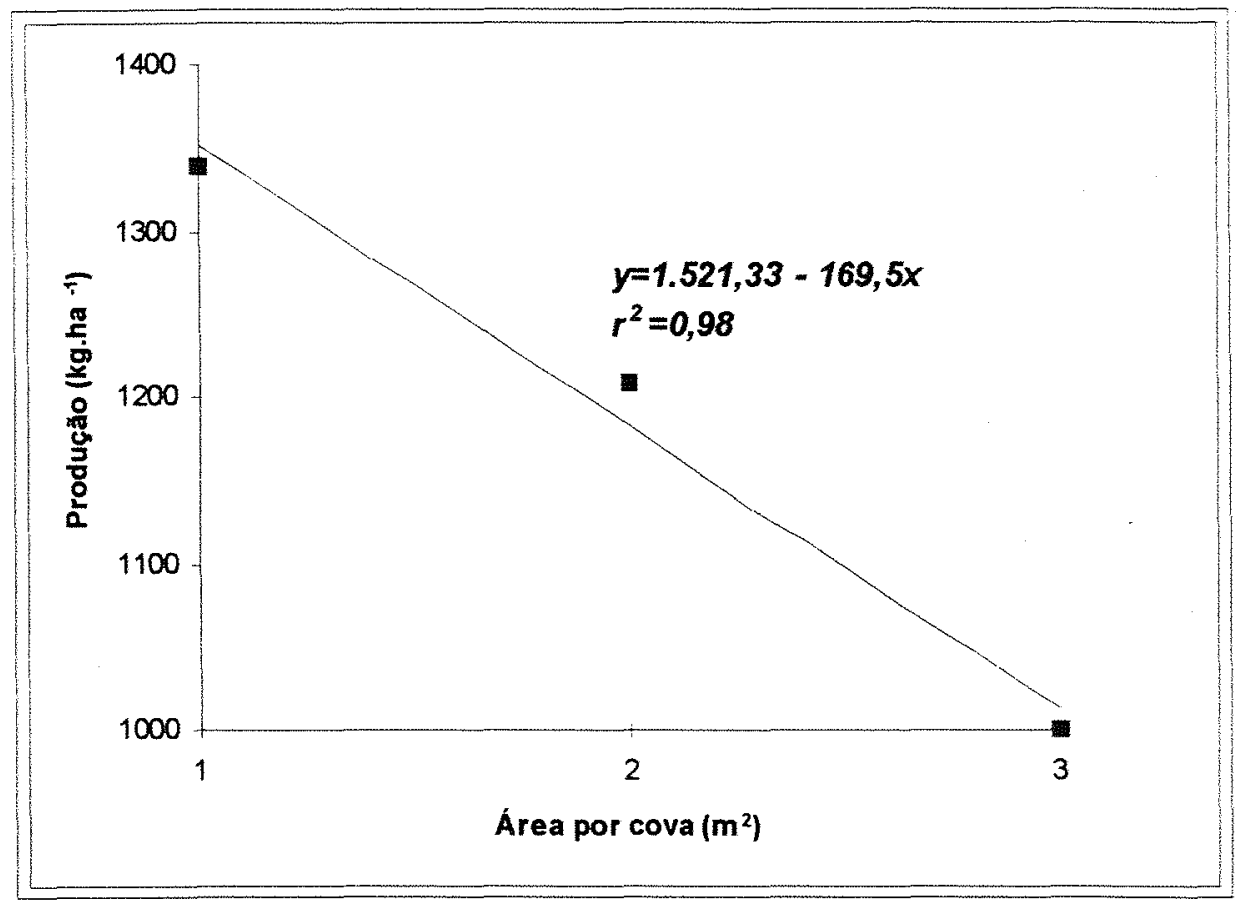

Figura 2: Gráfico da regressão linear entre a produção de café beneficiado da variedade Caturra, em kg.ha ${ }^{-1}$, e área por cova do primeiro ciclo de podas (1969-1973) no experimento 1

\subsubsection{Segundo ciclo de podas}

A Tabela 18 apresenta o resultado da análise de variância para os fatores estudados no segundo ciclo de podas.

O contraste entre as duas variedades adotadas no experimento foi significativo. As médias, apresentadas na Tabela 19, Calculadas a partir das médias dos tratamentos (Tabela 20), mostram grande superioridade de 'Mundo Novo' sobre 'Caturra'. Apesar dos espaçamentos menos adensados, 'Mundo Novo' foi $386 \%$ mais produtivo.

Para a densidade de $3 \mathrm{~m}^{2}$.cova ${ }^{-1}$, com duas plantas e podas "Beaumont \& Fukunaga", a variedade Mundo Novo apresentou média de produção $388 \%$ superior à variedade Caturra. A ausência de vigor desta variedade, associada à competição entre plantas na cova, podem explicar essa baixa produtividade.

Com a variedade 'Caturra', verifica-se pela Tabela 18, que 0 contraste entre a densidade de $5 \mathrm{~m}^{2}$ por cova e as densidades adensadas de plantio não foram significativas no período. As médias, apresentadas nas Tabelas 19 e 20, mostram produções muito baixas, tanto para o espaçamento largo quanto para os adensados com podas programadas, devido às suas características de menor vigor. 
Adotando-se espaçamentos adensados para a variedade 'Caturra' com podas programadas, verifica-se que há significância apenas para a tendência linear de produção em relação à área ocupada por cova (Tabela 18), com correlação negativa entre eles, conforme pode ser verificado pela Figura 3 e pêlos dados da Tabela 21.

O número de plantas por cova e a interação entre os fatores espaçamento e plantas por cova não foi significativo, evidenciando a inviabilidade da adoção de múltiplas plantas na cova de plantio em espaçamentos adensados com a variedade 'Caturra'.

O contraste entre o espaçamento adensado e não adensado para a variedade 'Mundo Novo' também mostrou-se significativo (Tabela 18) e as médias mostram, conforme apresentado na Tabela 19, uma maior produção média para os tratamentos com espaçamentos não adensados em relação ao espaçamento adensado com podas programadas.

As características de porte e maior vigor da variedade Mundo Novo propicia um fechamento da lavoura e no espaçamento adensado. A concorrência entre as covas causa diminuição da produtividade.

Após a sétima safra, iniciou-se a adoção de decote para o espaçamento largo com a variedade 'Mundo Novo', e tal prática mostrou-se significativa pelo teste $F$ (Tabela 18).

Na Tabela 22, é possível verificar uma queda na produção média do tratamento que sofreu a poda, em relação ao tratamento sem intervenção por poda, mostrando que a diminuição da área de produção na planta nesse período foi prejudicial à produtividade. Isto evidencia que foi precoce a adoção de decote após sete safras para a variedade Mundo Novo, plantada em espaçamento não adensado.

Neste período, vale a pena ressaltar que, conforme pode ser vislumbrado pela Tabela 21, apesar de haver tendência linear de aumento da produção com a redução de 3 para $1 \mathrm{~m}^{2}$ por cova com podas programadas na variedade 'Caturra', a adoção de $5 \mathrm{~m}^{2}$ por cova (não adensado) para essa variedade e conduzida sem podas, apresentou produção média (214 $\mathrm{kg}$ de café beneficiado por hectare), superior à adoção de $3 \mathrm{~m}^{2}$ por cova e próxima da produção da densidade de $2 \mathrm{~m}^{2}$ por cova. Tal fato, associado à menor utilização de mão-de-obra em espaçamentos não adensados, evidencia a superioridade desse tratamento. 
Tabela 18: Análise da variância do experimento 1 - Segundo ciclo de podas (1974-1978).

\begin{tabular}{|c|c|c|c|c|c|}
\hline Fonte de variação & $\mathbf{G L}$ & $\mathbf{S Q}$ & QM & $\mathbf{F}$ & \\
\hline Bloco & 3 & 56988 & 18996 & & \\
\hline (Tratamento) & (9) & $(3700224)$ & $(411136)$ & $(115,18)$ & ** \\
\hline Mundo Novo vs Caturra & 1 & 297050 & 297050 & 83,23 & $\star \star$ \\
\hline (dentro de Caturra) & (6) & (62124) & (10354) & $(2,90)$ & ** \\
\hline $5 \mathrm{~m}^{2}$ vs $\left[3,2,1 \mathrm{~m}^{2}\right]$ & 1 & 188 & 188 & 0,05 & \\
\hline (dentro de $3,2,1 \mathrm{~m}^{2}$ ) & (5) & (61935) & (12387) & $(3,47)$ & 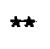 \\
\hline (Espaçamento) & (2) & (59390) & (29695) & $(8,32)$ & ** \\
\hline comp. Linear & 1 & 59049 & 59049 & 16,54 & ** \\
\hline comp. Quadrático & 1 & 341 & 341 & 0,10 & \\
\hline Plantas por Cova & 1 & 2204 & 2204 & 0,62 & \\
\hline Espaçam. $\times$ PI. por cova & 2 & 342 & 171 & 0,05 & \\
\hline (dentro de Mundo Novo) & (2) & $(3341050)$ & $(1670525)$ & $(468,07)$ & ** \\
\hline $6 \mathrm{~m}^{2}$ vs $3 \mathrm{~m}^{2}$ & 1 & 212816 & 212816 & 59,63 & ** \\
\hline (dentro de $6 \mathrm{~m}^{2}$ ) & (1) & $(3128234)$ & $(3128234)$ & $(876,50)$ & ** \\
\hline Livre cresc. vs Decote & 1 & 3128234 & 3128234 & 876,50 & ** \\
\hline Resíduo & 27 & 96363 & 3569 & & \\
\hline Total & 39 & 37153575 & & & \\
\hline $\begin{array}{l}\text { Média geral }=308,2 \\
\operatorname{CV}(\%)=19,4\end{array}$ & & & & & \\
\hline
\end{tabular}

Tabela 19: Médias de produção das variedades estudadas no experimento $1 \mathrm{em}$ kg. ha ${ }^{-1}$ de café beneficiado - Segundo ciclo de podas (1974-1978).

\begin{tabular}{lccc} 
& \multicolumn{2}{c}{ Sistema de plantio } & \\
\cline { 2 - 4 } Variedade & Não adens. (LC) & Adensado (BF) & Média \\
\hline Mundo Novo & $943(2)$ & $661(1)$ & $849(3)$ \\
Caturra & $214(1)$ & $221(6)$ & $220(7)$ \\
\hline
\end{tabular}

Entre parênteses está representado o número de tratamentos que compõem a média.

Tabela 20: Médias de produção dos tratamentos do experimento $1 \mathrm{em} \mathrm{kg} \cdot \mathrm{ha}^{-1}$ de café beneficiado - Segundo ciclo de podas (1974-1978).

\begin{tabular}{llclr}
\hline Variedade & Plantas por cova & Espaçamento & Sistema de Podas & Médias \\
\hline Mundo Novo & 2 Plantas/cova & $3,0 \times 2,0 \mathrm{~m}$ & Livre Crescimento & 1056 \\
& & $3,0 \times 2,0 \mathrm{~m}$ & Decote & 830 \\
& & $2,30 \times 1,30 \mathrm{~m}$ & Recepa BF & 661 \\
Caturra & & & & \\
& 2 Plantas/cova & $2,79 \times 1,79 \mathrm{~m}$ & Livre Crescimento & 214 \\
& & $2,30 \times 1,30 \mathrm{~m}$ & Recepa BF & 170 \\
& & $2,0 \times 1,0 \mathrm{~m}$ & Recepa BF & 231 \\
& \multirow{4}{*}{ 1 Plantas/cova } & $1,62 \times 0,62 \mathrm{~m}$ & Recepa BF & 291 \\
& & $2,30 \times 1,30 \mathrm{~m}$ & Recepa BF & 145 \\
& & $2,0 \times 1,0 \mathrm{~m}$ & Recepa BF & 222 \\
& & $1,62 \times 0,62 \mathrm{~m}$ & Recepa BF & 267 \\
\hline
\end{tabular}


Tabela 21: Médias de produção dos espaçamentos e número de plantas por cova estudados, com a variedade Caturra, no experimento 1 , em $\mathrm{kg} \cdot \mathrm{ha}^{-1}$ de café beneficiado - Segundo ciclo de podas (1974-1978).

\begin{tabular}{ccccc}
\hline & \multicolumn{3}{c}{ Área por cova } & \\
\cline { 2 - 5 } PI. por cova & $\mathbf{2 , 3 0 \times 1 , 3 0 ~} \mathbf{m}$ & $\mathbf{2 , 0} \times \mathbf{1 , 0} \mathbf{m}$ & $\mathbf{1 , 6 2 \times 0 , 6 2} \mathbf{m}$ & Média \\
\hline 1 & 145 & 222 & 267 & 211 \\
2 & 170 & 231 & 291 & 231 \\
Média & 158 & 226 & 279 & \\
\hline
\end{tabular}

Tabela 22: Médias de produção dos sistemas de podas estudados, com a variedade Mundo Novo, no experimento 1 , em $\mathrm{kg}^{-1} \mathrm{ha}^{-1}$ de café beneficiado - Segundo ciclo de podas (19741978).

\begin{tabular}{cc}
\hline Sistema de podas & Média \\
\hline Livre crescimento & 1.056 \\
Decote & 830 \\
\hline
\end{tabular}

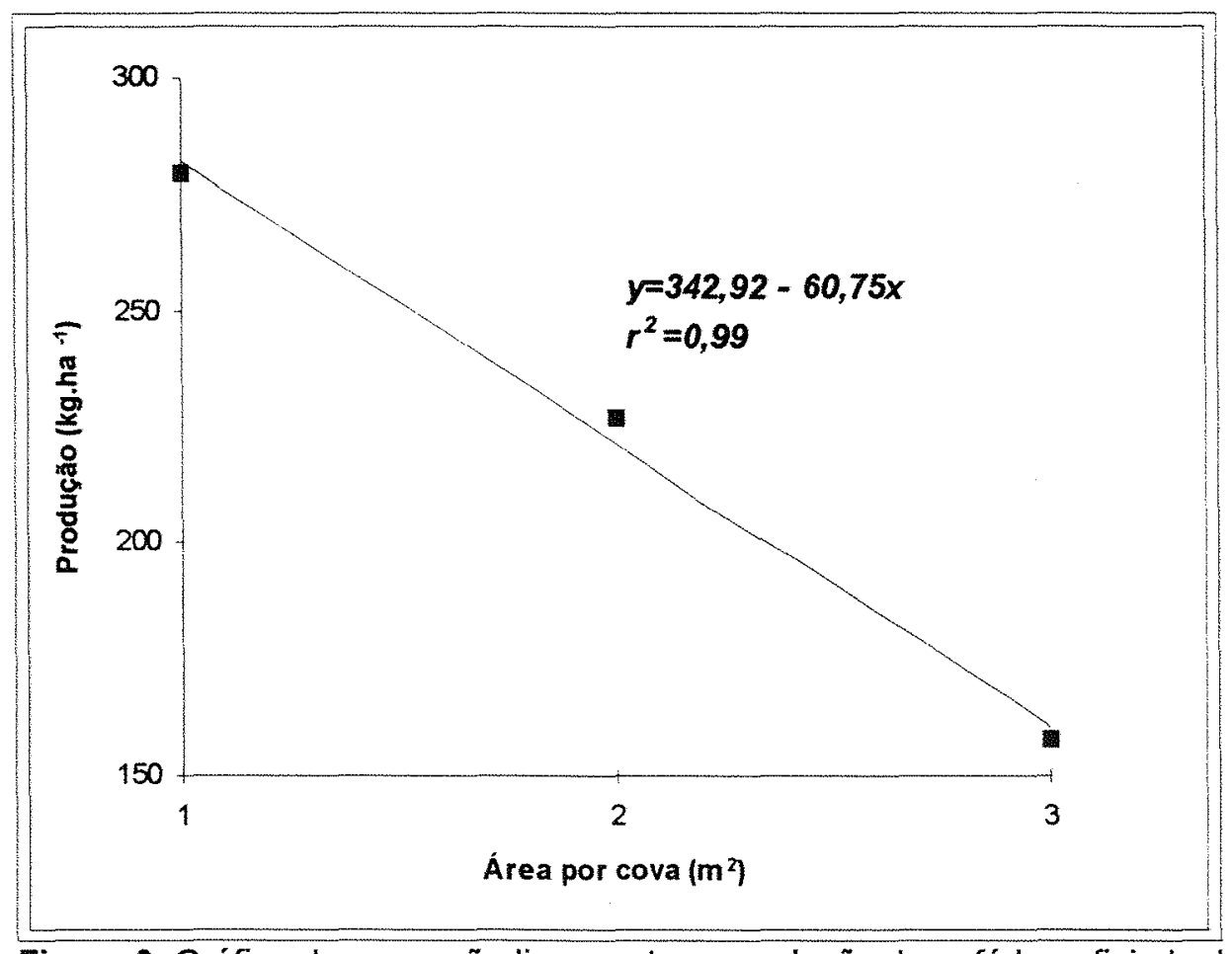

Figura 3: Gráfico da regressão linear entre a produção de café beneficiado da variedade Caturra, em kg.ha-1 ${ }^{-1}$ e área por cova do segundo ciclo de podas (1974-1978) no experimento 1 


\subsubsection{Terceiro ciclo de podas}

$O$ último ciclo de podas avaliado, que corresponde ao período compreendido entre a $13^{\mathrm{a}}$ e a $17^{\text {a }}$ safra, conforme a Tabela 23 , mostra que o contraste entre as duas variedades é altamente significativo. Suas produções médias demonstram uma produtividade $650 \%$ superior de 'Mundo Novo' sobre 'Caturra' (Tabela 24). A variedade Caturra, tanto nesse período como no anterior, apresentou produções médias inferiores a $240 \mathrm{~kg}$ de café beneficiado por hectare (quatro sacas).

Apesar da baixa produção média geral da variedade Caturra no periodo verifica-se que o contraste entre os espaçamentos adensados e o não adensado foi significativo (Tabela 23). As médias, apresentadas na Tabela 24, calculadas pelas médias dos tratamentos (Tabela 25), demonstram produção superior (35\%) do espaçamento não adensado.

Considerando-se os espaçamentos adensados para 'Caturra', apenas a tendência linear da produção com relação ao espaçamento foi significativa (Tabela 23) e, mais uma vez, houve queda de produção com a diminuição da densidade de plantio (Figura 4). A produção média (250 kg.ha ${ }^{-1}$ ) do espaçamento não adensado e conduzido sem podas (Tabela26), embora baixa, foi superior à produção das densidades $3 \mathrm{a} 2 \mathrm{~m}^{2}$ por cova e próxima da de $1 \mathrm{~m}^{2}$ por cova.

Com a variedade 'Mundo Novo', por seu lado o contraste entre o espaçamento adensado $\left(3 \mathrm{~m}^{2}\right.$ por cova) com podas programadas e os tratamentos não adensados $\left(6 \mathrm{~m}^{2}\right.$ por cova) foi significativo (Tabela 23). As médias, apresentadas na Tabela 24, mostram uma produtividade média bem superior dos tratamentos não adensados em relação ao adensado.

Apesar das podas programadas, o fechamento entre os cafeeiros 'Mundo Novo' provocou decréscimo da produção no período.

O contraste entre a adoção ou não de poda tipo decote no espaçamento não adensado para 'Mundo Novo' não foi significativo pelo teste $F$ (Tabela 23). As médias de produção são apresentadas na Tabela 27. No entanto, os cafeeiros quando decotados, principalmente de variedades de porte alto, apresentam o manejo da lavoura facilitado, como a colheita e tratos culturais, aumentando assim o rendimento da mão-de-obra.

A falta de vigor da variedade 'Caturra', fica evidente quando se compara a produção média dessa variedade em densidade de $3 \mathrm{~m}^{2}$ por cova com duas plantas e conduzida com podas pré-determinadas. Com o mesmo tratamento a variedade Mundo Novo (Tabela 25) produziu 6,2 vezes mais que a variedade Caturra. 
Tabela 23: Análise da variância do experimento 1 - Terceiro ciclo de podas (1979-1983).

\begin{tabular}{|c|c|c|c|c|c|}
\hline Fonte de variação & GL & $\mathbf{S Q}$ & QM & $\mathbf{F}$ & \\
\hline Bloco & 3 & 44265 & 14755 & & \\
\hline (Tratamento) & (9) & (10671948) & $(1185772)$ & $(120,09)$ & $* \star$ \\
\hline Mundo Novo vs Caturra & 1 & 9593805 & 9593805 & 971,62 & ** \\
\hline (dentro de Caturra) & (6) & $(111720)$ & $(18620)$ & $(1,89$ & \\
\hline $5 \mathrm{~m}^{2}$ vs $\left[3,2,1 \mathrm{~m}^{2}\right]$ & 1 & 766362 & 766362 & 77,61 & $\star \star$ \\
\hline (dentro de $3,2,1 \mathrm{~m}^{2}$ ) & (5) & (97765) & (19553) & $(1,98)$ & \\
\hline (Espaçamento) & (2) & (73826) & (36913) & $(3,74)$ & * \\
\hline comp. Linear & 1 & 70968 & 70968 & 7,19 & $\star \star$ \\
\hline comp. Quadrático & 1 & 2858 & 2858 & 0,29 & \\
\hline Plantas por Cova & 1 & 20556 & 20556 & 2,08 & \\
\hline Espaçam. X PI. por cova & 2 & 3380 & 1690 & 0,17 & \\
\hline (dentro de Mundo Novo) & (2) & (966422) & $(483211)$ & $(48,94)$ & ** \\
\hline $6 \mathrm{~m}^{2}$ vs $3 \mathrm{~m}^{2}$ & 1 & 963843 & 963843 & 97,61 & $\star \star$ \\
\hline (dentro de $6 \mathrm{~m}^{2}$ ) & (1) & $(2578)$ & $(2578)$ & $(0,26)$ & \\
\hline Livre cresc. vs Decote & 1 & 2578 & 2578 & 0,26 & \\
\hline Resíduo & 27 & 266598 & 9874 & & \\
\hline Total & 39 & 10982811 & & & \\
\hline $\begin{array}{l}\text { Média geral }=510,1 \\
\operatorname{CV}(\%)=19,4\end{array}$ & & & & & \\
\hline
\end{tabular}

Tabela 24: Médias de produção das variedades estudadas no experimento $1 \mathrm{em}$ kg.ha ${ }^{-1}$ de café beneficiado - Terceiro ciclo de podas (1979-1983).

\begin{tabular}{|c|c|c|c|}
\hline \multirow[b]{2}{*}{ Variedade } & \multicolumn{2}{|c|}{ Sistema de plantio } & \multirow[b]{2}{*}{ Média } \\
\hline & Não adens. (LC) & Adensado (BF) & \\
\hline $\begin{array}{l}\text { Mundo Novo } \\
\text { Caturra }\end{array}$ & $\begin{array}{c}1.464(2) \\
250(1)\end{array}$ & $\begin{array}{l}863(1) \\
186(6)\end{array}$ & $\begin{array}{c}1.264(3) \\
195(7)\end{array}$ \\
\hline
\end{tabular}

Entre parênteses está representado o número de tratamentos que compõem a média.

Tabela 25: Médias de produção dos tratamentos do experimento $1 \mathrm{em} \mathrm{kg.ha-1}$ de café beneficiado - Terceiro ciclo de podas (1979-1983).

\begin{tabular}{rcclr}
\hline Variedade & Plantas por cova & Espaçamento & Sistema de Podas & Médias \\
\hline Mundo Novo & 2 Plantas/cova & $3,0 \times 2,0 \mathrm{~m}$ & Livre Crescimento & 1447 \\
& & $3,0 \times 2,0 \mathrm{~m}$ & Decote & 1481 \\
& & $2,30 \times 1,30 \mathrm{~m}$ & Recepa BF & 863 \\
Caturra & \multirow{3}{*}{ 2 Plantas/cova } & $2,79 \times 1,79 \mathrm{~m}$ & Livre Crescimento & 250 \\
& & $2,30 \times 1,30 \mathrm{~m}$ & Recepa BF & 139 \\
& & $2,0 \times 1,0 \mathrm{~m}$ & Recepa BF & 207 \\
& \multirow{4}{*}{ 1 Plantas/cova } & $1,62 \times 0,62 \mathrm{~m}$ & Recepa BF & 299 \\
& & $2,30 \times 1,30 \mathrm{~m}$ & Recepa BF & 114 \\
& & $2,0 \times 1,0 \mathrm{~m}$ & Recepa BF & 134 \\
& & $1,62 \times 0,62 \mathrm{~m}$ & Recepa BF & 221 \\
\hline
\end{tabular}


Tabela 26: Médias de produção dos espaçamentos e número de plantas por cova estudados com a variedade Caturra no experimento 1 , em $\mathrm{kg} \mathrm{ha}^{-1}$ de café beneficiado - Terceiro ciclo de podas (1979-1983).

\begin{tabular}{ccccc}
\hline & \multicolumn{3}{c}{ Área por cova } & \\
\cline { 2 - 5 } PI. por cova & $2,30 \times 1,30 \mathrm{~m}$ & $\mathbf{2 , 0} \times 1,0 \mathrm{~m}$ & $\mathbf{1 , 6 2 \times 0 , 6 2 \mathrm { m }}$ & Média \\
\hline 1 & 114 & 134 & 221 & 156 \\
2 & 139 & 207 & 299 & 215 \\
Média & 127 & 170 & 260 & \\
\hline
\end{tabular}

Tabela 27: Médias de produção dos sistemas de podas estudados, com a variedade Mundo Novo, no experimento 1 , em $\mathrm{kg}$ ha $^{-1}$ de café beneficiado - Terceiro ciclo de podas (19791983).

\begin{tabular}{cc}
\hline Sistema de podas & Média \\
\hline Livre crescimento & 1.387 \\
Decote & 1.481 \\
\hline
\end{tabular}

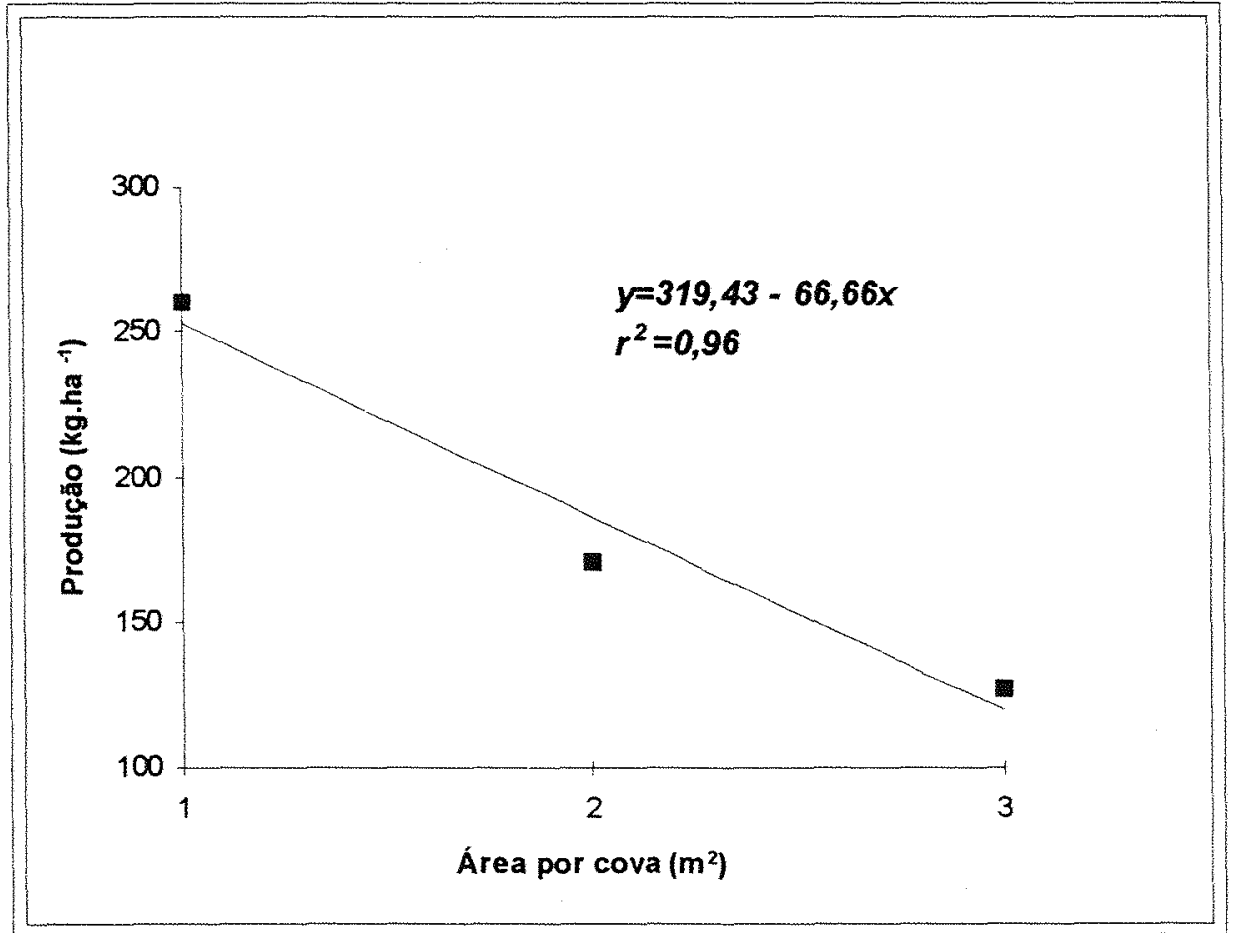

Figura 4: Gráfico da regressão linear entre a produção de café beneficiado da variedade Caturra, em kg.ha ${ }^{-1}$, e área por cova do terceiro ciclo de podas (1979-1983) no experimento 1 


\subsubsection{Média geral das 17 colheitas}

Para se conhecer o comportamento da produção nos diversos sistemas de condução dos cafeeiros adotados nesse experimento, foi feita a análise da produtividade média das 17 colheitas realizadas no periodo. As médias de produção dos tratamentos são apresentadas na Tabela 28.

A análise estatística realizada apresentou significância pelo teste $F$ para o contraste entre as variedades (Tabela 29) e as médias são apresentadas Tabela 30 . A produtividade média em 'Mundo Novo' foi aproximadamente o dobro que em 'Caturra', mostrando a inviabilidade do plantio de 'Caturra' por longos períodos nas condições da região.

Para a variedade 'Caturra' o contraste entre o plantio em espaçamento não adensado e os espaçamentos adensados também foi significativo (Tabela 29) e as médias (Tabela 30), mostram uma superioridade dos espaçamentos adensados, em virtude da elevada produção inicial desses espaçamentos, refletindo na média geral das 17 colheitas.

Nos espaçamentos adensados para a variedade 'Caturra', a tendência linear para a densidade de plantio e o número de plantas por cova também foram significativos (Tabela 29).

Mantendo-se a tendência de cada período estudado, a redução da densidade de plantio promoveu, como consequência, redução na produção média, conforme pode ser visualizado na Figura 5 e pelos dados das Tabelas 28 e 31.

Com relação ao número de plantas por cova, a maior produção apresentada quando da adoção de duas plantas (Tabela 31) parece ser, ainda, reflexo da elevada produção inicial.

Com a variedade 'Mundo Novo', as diferenças entre os tratamentos largos foram significativamente diferentes do tratamento adensado (Tabela 32) e apresentaram uma produção maior para os não adensados (Tabela 30 ).

Diferentemente de 'Caturra', a variedade Mundo Novo não teve queda pronunciada na produção ao longo dos períodos, a maior produção inicial constatada no tratamento adensado não influenciou de forma marcante a média de produção das 17 colheitas.

A intervenção por decote após a sétima safra não alterou significativamente a média das 17 colheitas (Tabela 29). As produções médias são apresentadas na Tabela 32.

Considerando-se a produção das dez colheitas realizadas após a intervenção por decote, verifica-se uma média de produção de 1.073 e $1.039 \mathrm{~kg}$ de café beneficiado por hectare, respectivamente para os tratamentos com livre crescimento e decotado (Tabela 32).

Apesar de não apresentar vantagem em termos de produção, a aplicação da poda tipo decote em variedades muito vigorosas, facilita o manejo e assim, o rendimento da mão-de-obra é incrementado, devendo tal fato ser considerado na tomada de decisão quanto a sua adoção.

O menor vigor da variedade Caturra e sua inadequação a utilização em Ionga duração nas condições locais, fica expressa quando se compara as médias apresentadas na Tabela 28. 
Com densidade de $3 \mathrm{~m}^{2}$, duas plantas por cova e condução com recepas programadas a produção média de 'Caturra' foi 2,2 vezes menor que 'Mundo Novo'.

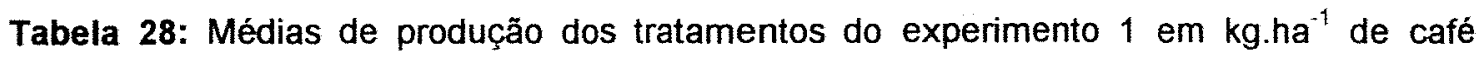
beneficiado - Média geral das 17 colheitas (1967-1983).

\begin{tabular}{cccllr}
\hline Variedade & Plantas por cova & Espaçamento & Sistema de Podas & Médias \\
\hline Mundo Novo & 2 Plantas/cova & $3,0 \times 2,0 \mathrm{~m}$ & Livre Crescimento & 1447 \\
& & $3,0 \times 2,0 \mathrm{~m}$ & Decote & 1347 \\
& & $2,30 \times 1,30 \mathrm{~m}$ & Recepa BF & 1227 \\
Caturra & \multirow{3}{*}{ 2 Plantas/cova } & $2,79 \times 1,79 \mathrm{~m}$ & Livre Crescimento & 533 \\
& & $2,30 \times 1,30 \mathrm{~m}$ & Recepa BF & 553 \\
& & $2,0 \times 1,0 \mathrm{~m}$ & Recepa BF & 734 \\
& \multirow{4}{*}{ 1 Plantas/cova } & $1,62 \times 0,62 \mathrm{~m}$ & Recepa BF & 947 \\
& & $2,30 \times 1,30 \mathrm{~m}$ & Recepa BF & 481 \\
& & $2,0 \times 1,0 \mathrm{~m}$ & Recepa BF & 633 \\
& & $1,62 \times 0,62 \mathrm{~m}$ & Recepa BF & 863 \\
\hline
\end{tabular}

Tabela 29: Análise da variância do experimento 1 - Média geral das 17 colheitas (19671983).

\begin{tabular}{|c|c|c|c|c|}
\hline Fonte de variação & $\mathbf{G L}$ & $\mathbf{S Q}$ & QM & $\mathbf{F}$ \\
\hline $\begin{array}{l}\text { Bloco } \\
\text { (Tratamento) }\end{array}$ & $\begin{array}{c}3 \\
(9)\end{array}$ & $\begin{array}{r}98331 \\
(4526091)\end{array}$ & $\begin{array}{r}32777 \\
(502899)\end{array}$ & $(69.94) * *$ \\
\hline Mundo Novo vs Caturra & 1 & 3680974 & 3680974 & 511.96 * \\
\hline (dentro de Caturra) & (6) & (747996) & $(124666)$ & $(17,34)$ \\
\hline $5 \mathrm{~m}^{2}$ vs $\left[3,2,1 \mathrm{~m}^{2}\right]$ & 1 & 98002 & 98002 & 13,63 \\
\hline (dentro de $3,2,1 \mathrm{~m}^{2}$ ) & (5) & $(649995)$ & (129999) & $(18,08)$ \\
\hline (Espaçamento) & (2) & $(604736)$ & (302368) & $(42,05)$ \\
\hline comp. Linear & 1 & 600718 & 600718 & 83,55 \\
\hline comp. Quadrático & 1 & 4019 & 4019 & 0.56 \\
\hline Plantas por Cova & 1 & 44416 & 44416 & $6,18 *$ \\
\hline Espaçam. X PI. por cova & 2 & 840 & 420 & 0,06 \\
\hline (dentro de Mundo Novo) & (2) & $(97126)$ & (48563) & $(6,75) *$ \\
\hline $6 \mathrm{~m}^{2}$ vs $3 \mathrm{~m}^{2}$ & 1 & 77173 & 77173 & 10,73 * \\
\hline (dentro de $6 \mathrm{~m}^{2}$ ) & (1) & (199953) & (19953) & $(2,77)$ \\
\hline Livre cresc. vs Decote & 1 & 199953 & 19953 & 2,77 \\
\hline Resíduo & 27 & 194130 & 7190 & \\
\hline Total & 39 & 4818552 & & \\
\hline $\begin{array}{l}\text { Média geral = } 761,2 \\
C V(\%)=11,1\end{array}$ & & & & \\
\hline
\end{tabular}


Tabela 30: Médias de produção das variedades estudadas no experimento $1 \mathrm{em}$ kg.ha ${ }^{-1}$ de café beneficiado - Média geral das 17 colheitas (1967-1983).

\begin{tabular}{|c|c|c|c|}
\hline \multirow[b]{2}{*}{ Variedade } & \multicolumn{2}{|c|}{ Sistema de plantio } & \multirow[b]{2}{*}{ Média } \\
\hline & Não adens. (LC) & Adensado (BF) & \\
\hline $\begin{array}{l}\text { Mundo Novo } \\
\text { Caturra }\end{array}$ & $\begin{array}{c}1.397(2) \\
533(1)\end{array}$ & $\begin{array}{c}1.227(1) \\
702(6)\end{array}$ & $\begin{array}{c}1.340(3) \\
678(7)\end{array}$ \\
\hline
\end{tabular}

Entre parênteses está representado o número de tratamentos que compõem a média.

Tabela 31: Médias de produção dos espaçamentos e número de plantas por cova estudados com a variedade Caturra no experimento 1 , em $\mathrm{kg}_{\text {.ha }}{ }^{-1}$ de café beneficiado - Média geral das 17 colheitas (1967-1983).

\begin{tabular}{ccccc}
\hline & \multicolumn{3}{c}{ Área por cova } & \\
\cline { 2 - 5 } PI. por cova & $\mathbf{2 , 3 0 \times 1 , 3 0 ~} \mathbf{m}$ & $\mathbf{2 , 0} \times \mathbf{1 , 0} \mathbf{m}$ & $\mathbf{1 , 6 2 \times 0 , 6 2 \mathrm { m }}$ & Média \\
\hline 1 & 481 & 633 & 863 & 659 \\
2 & 553 & 734 & 947 & 745 \\
Média & 517 & 683 & 905 & \\
\hline
\end{tabular}

Tabela 32: Médias de produção nos sistemas de podas estudados com a variedade Mundo Novo no experimento 1 , em kg.ha- ${ }^{-1}$ de café beneficiado - Média geral das 17 colheitas (1967-1983).

\begin{tabular}{ccc}
\hline Sistema de podas & Média $\left(17^{2}\right)$ & Média $\left(10^{b}\right)$ \\
\hline Livre crescimento & 1.190 & 1.073 \\
Decote & 1.125 & 1.039 \\
\hline média das 17 colheitas; ${ }^{\circ}$ média das 10 colheitas após a poda \\
(decote).
\end{tabular}




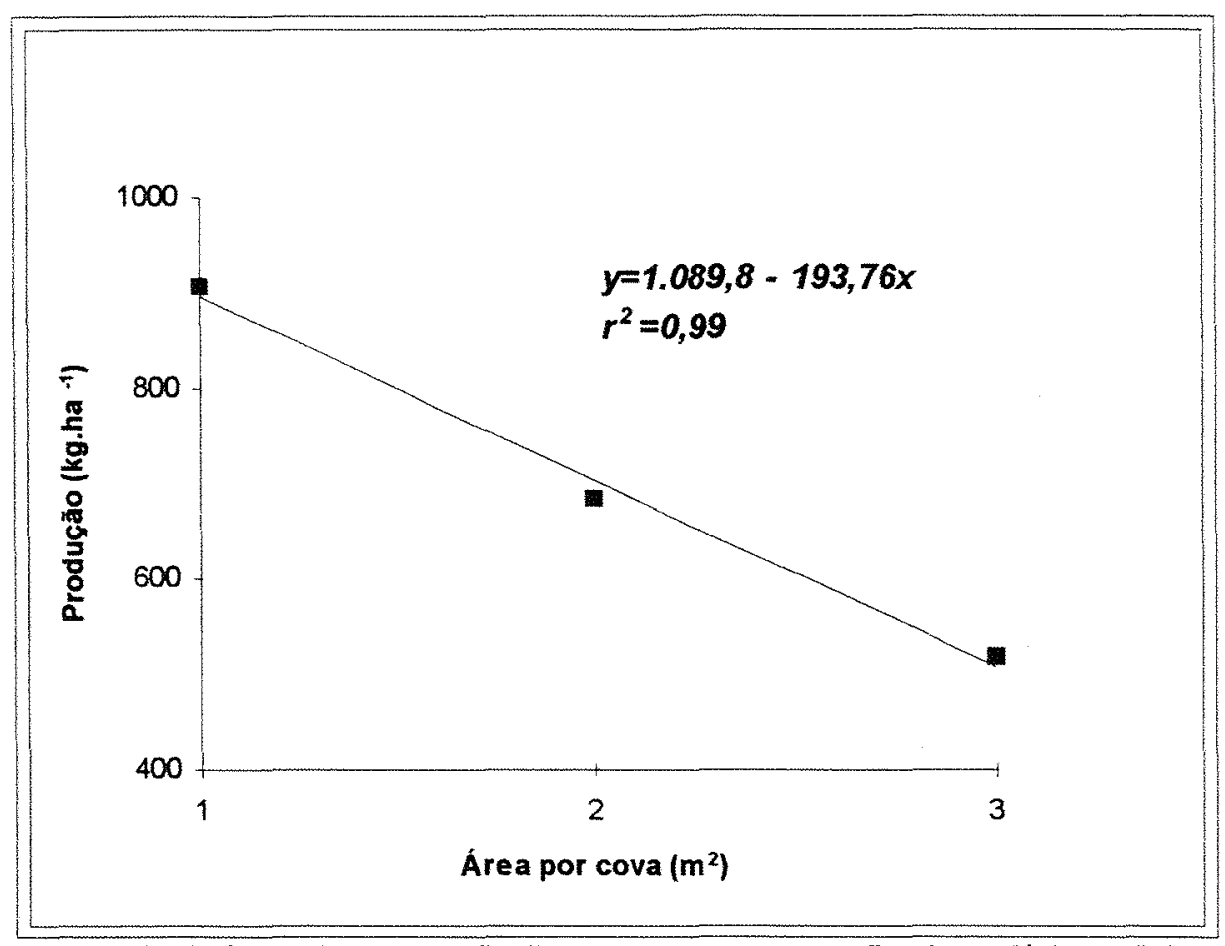

Figura 5: Gráfico da regressão linear entre a produção de café beneficiado da variedade Caturra, em $\mathrm{kg} \cdot \mathrm{ha}^{-1}$, e área por cova do média geral das 17 colheitas (1967-1983) no experimento 1

\subsubsection{Variação dos fatores ao longo dos periodos}

Com os dados provenientes das Tabelas 11, 12, 16, 17, 19, 21, 22, 24, 26 e 27, foram plotados as Figuras $6,7,8,9,10$ e 11.

As produtividades médias das variedades estão apresentadas na Figura 6 . Os resultados mostram produções mais elevadas de 'Caturra' em relação a 'Mundo Novo' nas duas primeiras safras e, como exposto anteriormente, essa maior produtividade foi causada não apenas pelas características das variedades, mas também pelo fato de 'Mundo Novo' ter sido cultivado em densidade de plantio menor do que 'Caturra'. Nesta fase jovem do cafeeiro, ainda não havia se iniciado a concorrência entre plantas nos espaçamentos mais adensados e nem os diversos problemas que o fechamento das lavouras ocasionam, além de não ter iniciado as podas regulares.

Observa-se também que, com o desenvolvimento da cultura, ocorreu acentuada queda de produção na variedade Caturra, enquanto 'Mundo Novo' manteve o potencial produtivo até o final do periodo avaliado. Na média geral das 17 colheitas, os tratamentos com 'Mundo Novo' apresentaram produtividade próxima de $100 \%$ superior aos tratamentos com 'Caturra' (Tabela 30). 
Com a variedade Caturra, em todos os períodos estudados, foram encontradas diferenças significativas entre os sistemas com densidades de $5 \mathrm{~m}^{2}$ por cova (conduzidos sem podas, considerado não adensado), e os sistemas com densidades de 3,2 e $1 \mathrm{~m}^{2}$ por cova conduzidos com podas programadas (adensados).

Na Figura 7 estão plotadas as médias de produtividade em função dos sistemas nos períodos estudados. Em ambos os sistemas, houve pronunciada queda de produtividade ao longo dos períodos, porém esse decréscimo foi mais acentuado nos tratamentos em espaçamentos adensados com podas programadas. No biênio inicial, os adensados apresentaram produções 2 vezes superiores ao espaçamento largo $\left(5 \mathrm{~m}^{2}\right)$; no segundo período (primeiro ciclo de podas) a produção foi de apenas 1,24 vezes superior; não diferiu significativamente no terceiro período (segundo ciclo de podas) e foi 1,34 vezes inferior no último período (terceiro ciclo de podas).

Apesar de ser o decréscimo de produção mais acentuado nos espaçamentos adensados, tanto nas maiores densidades de plantio como no espaçamento largo houve elevada queda na produtividade entre o primeiro e o segundo ciclo de podas, mostrando baixa

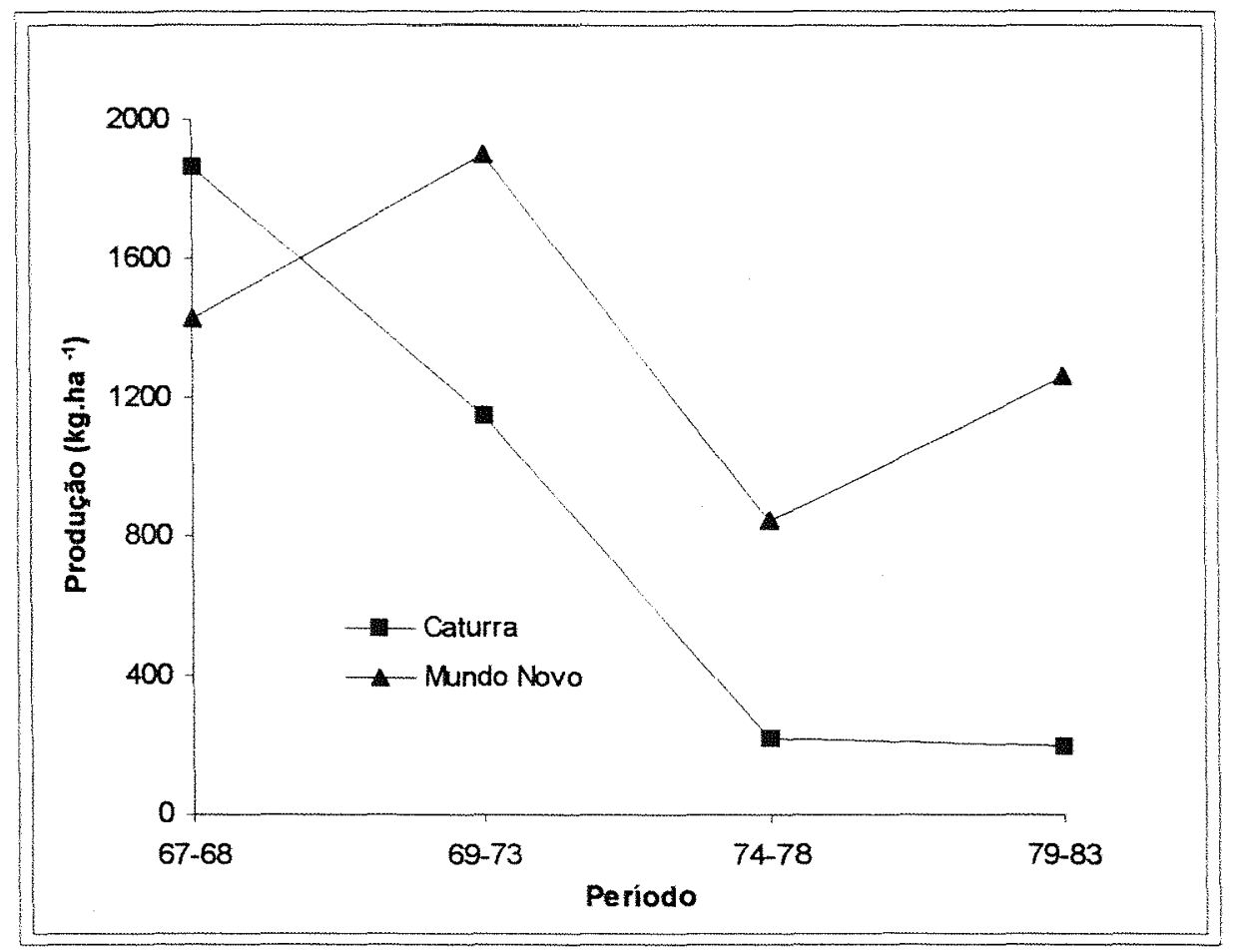

Figura 6: Representação gráfica da produção média de café beneficiado, em $\mathrm{kg} \cdot \mathrm{ha}^{-1}$, das variedades testadas ao longo dos períodos estudados experimento 1 


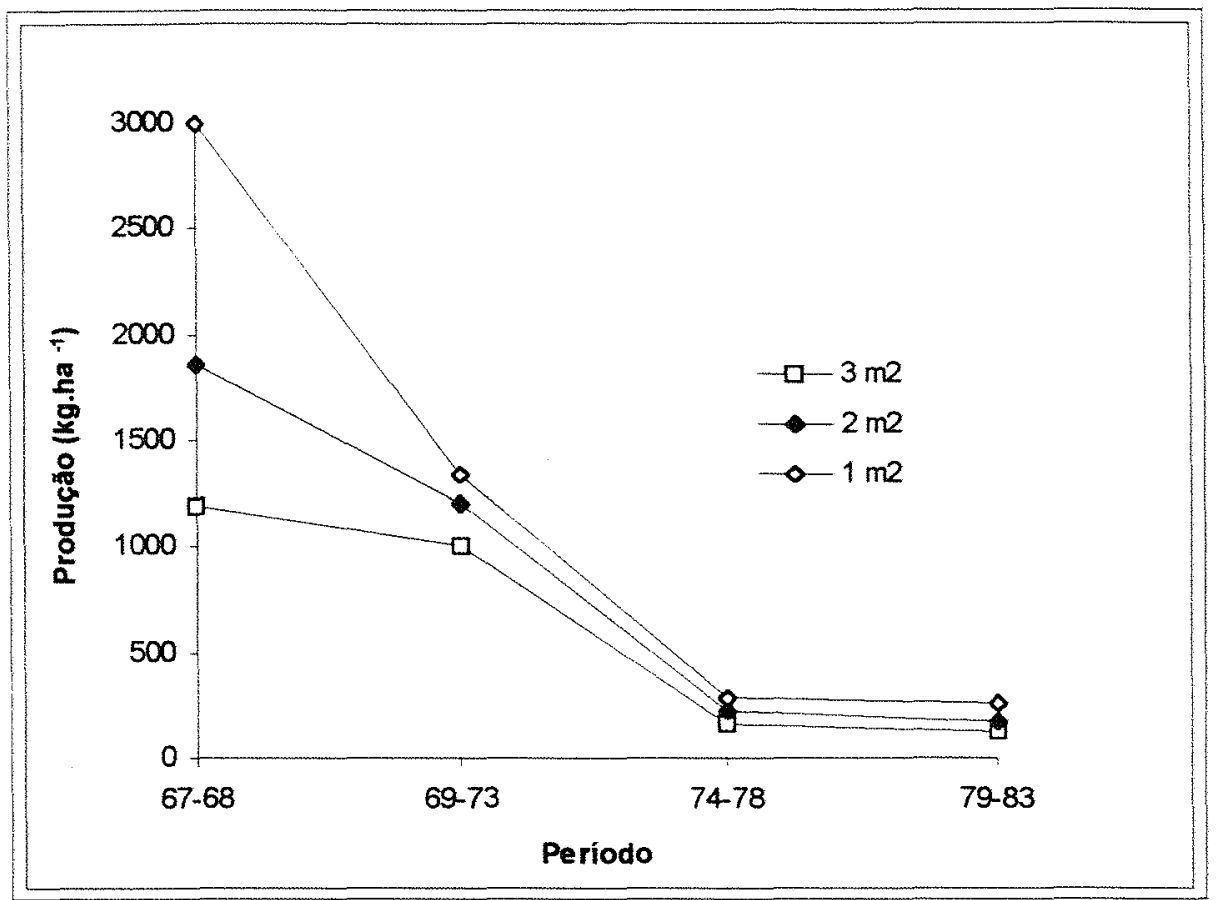

Figura 7: Representação gráfica da produção média de café beneficiado, em kg.ha ${ }^{-1}$, dos sistemas de plantio testados com a variedade Caturra ao longo dos períodos estudados - experimento 1

viabilidade da produção de Caturra após 7 safras para as condições do experimento e da região.

Entre os espaçamentos adensados para a variedade Caturra, o espaçamento foi significativo para todos os periodos seguindo o modelo de regressão linear, onde a produção diminuiu com o aumento da área ocupada por cova. Esse decréscimo diminui ao longo dos periodos, apresentando coeficientes angulares $\left(\beta_{1}\right)$ de: $-905 ;-169,5 ;-60,75$ e $-66,6$ para 0 biênio inicial e os ciclos de podas (primeiro, segundo e terceiro, respectivamente), conforme pode ser visualizado nos Figuras 1,2,3 e 4. Esses resultados permitem concluir que as diferenças de produção entre as três densidades estudadas diminui ao longo dos períodos estudados, conforme mostra o Figura 8. 


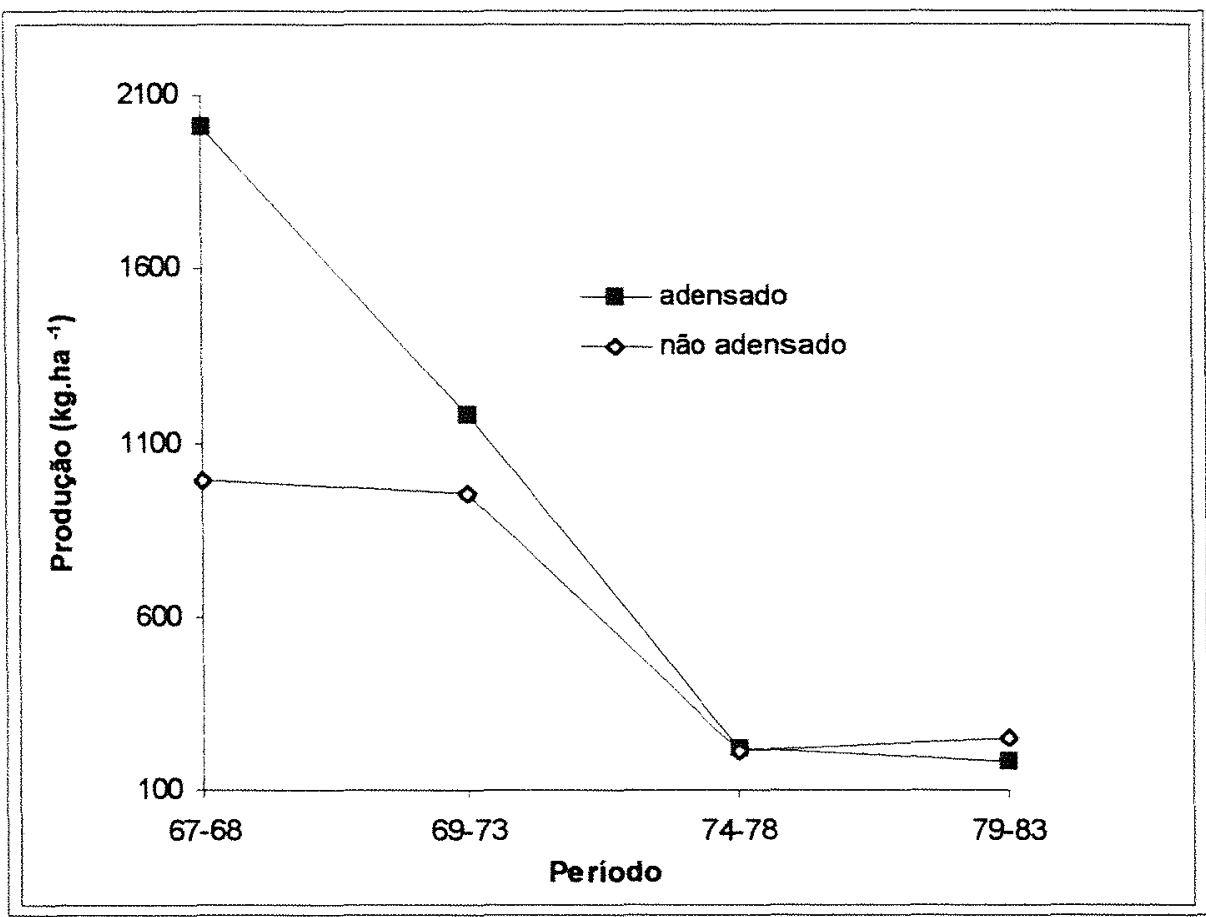

Figura 8: Representação gráfica da produção média de café beneficiado, em kg.ha ${ }^{-1}$, dos espaçamentos adensados com a variedade Caturra ao longo dos períodos estudados - experimento 1

Com relação ao número de plantas por cova para a variedade Mundo Novo, foram constatadas diferenças significativas apenas para o biênio inicial e para a média das 17 safras. Pelas produções médias plotadas na Figura 9, verifica-se que o uso de 2 plantas por cova foi superior ao uso de 1 planta, apenas no biênio inicial. Neste caso, a decisão pela adoção de 1 ou 2 plantas por cova em plantios adensados merece ser regida à luz de critérios econômicos, com relação ao custo de implantação da lavoura e do retorno apresentado nas duas primeiras safras. 


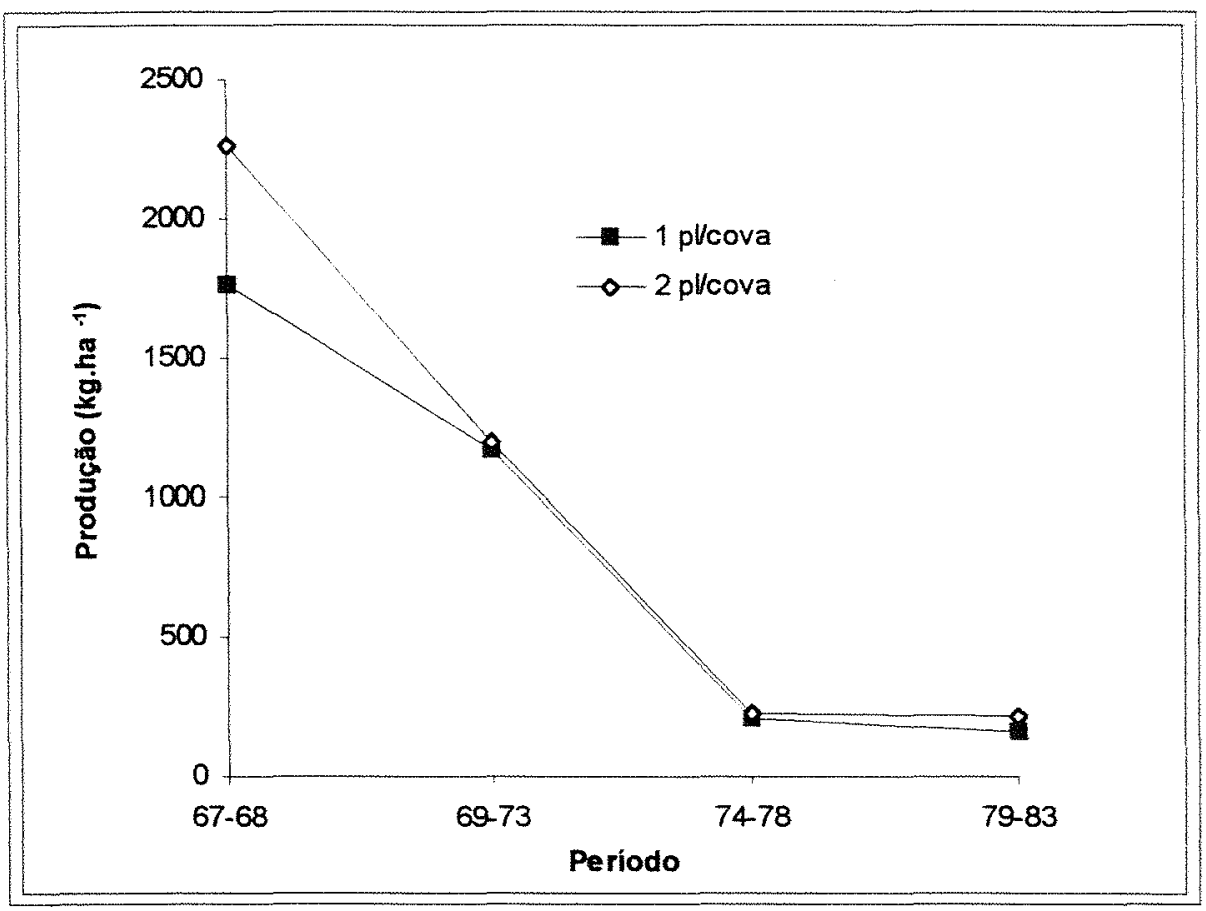

Figura 9: Representação gráfica da produção média de café beneficiado, em kg.ha ${ }^{-1}$, com o plantio de 1 ou 2 plantas por cova na variedade Mundo Novo ao longo dos periodos estudados - experimento 1.

Como a média de produção do biênio inicial foi substancialmente superior aos demais períodos, a média de produção nas 17 safras também resultou em diferenças significativas para número de plantas por cova, todavia, o aumento da produtividade na média geral com a adoção de 2 plantas por cova em relação a 1 planta foi menor que no biênio inicial (Tabela 31).

Esses resultados diferem dos encontrados por Henao \& Mestre (1988) que concluíram haver diferenças de produção em função do número de plantas por cova em um mesmo espaçamento, mas não são diferentes quando o número de plantas. ha ${ }^{-1}$ for igual.

Em Mundo Novo, comparando-se o plantio adensado ( $3 \mathrm{~m}^{2}$ por cova) com o cultivo do cafeeiro em espaçamento largo $\left(6 \mathrm{~m}^{2}\right.$ por cova), verificou-se não haver diferenças significativas apenas para o primeiro ciclo de podas (periodo 1969-1973). As médias plotadas na Figura 10, mais uma vez evidencia a maior produtividade do cafezal adensado nas primeiras safras. Entretanto essa situação se inverte após as 7 primeiras colheitas, sendo que a produtividade no espaçamento largo foi superior ao adensado, mesmo adotando-se as podas programadas. 


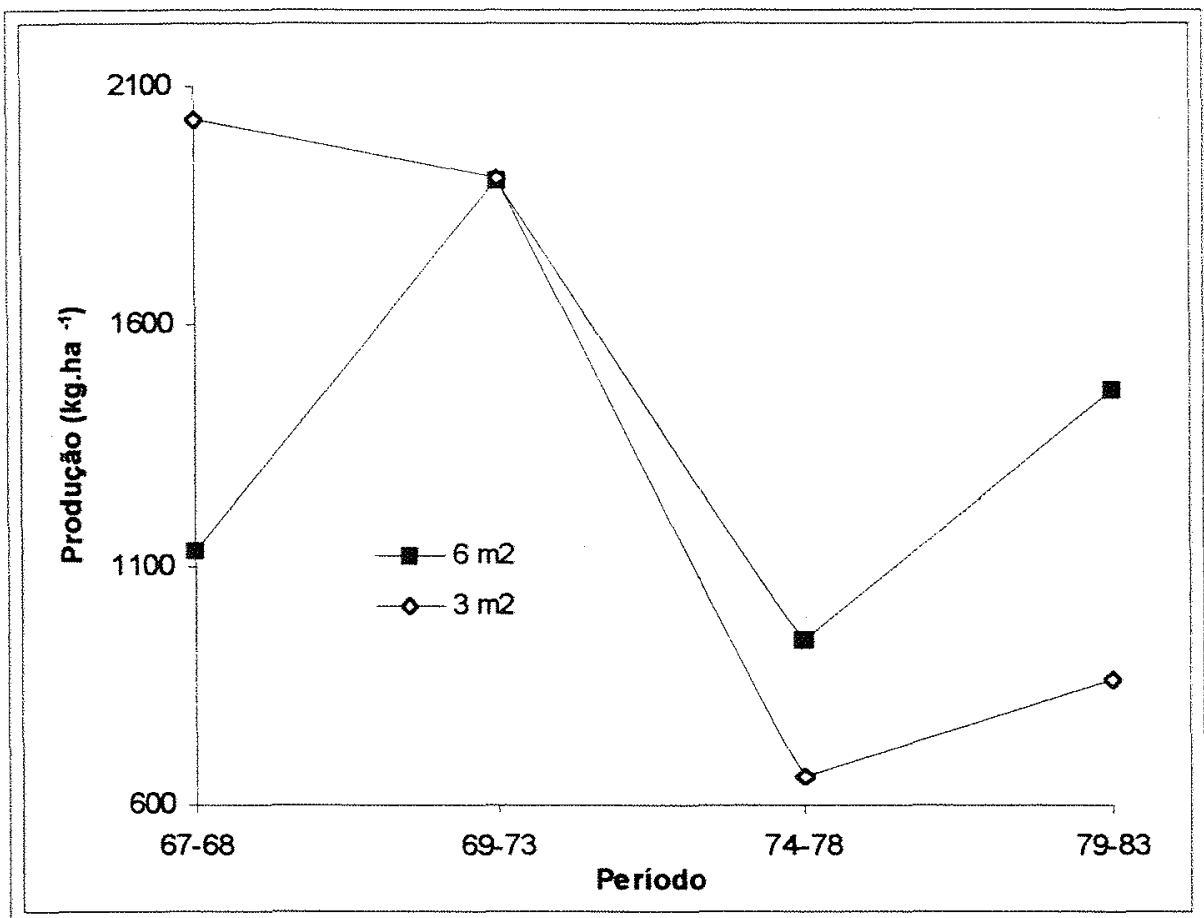

Figura 10: Representação gráfica da produção média de café beneficiado, em kg.ha ${ }^{-1}$, dos sistemas de plantio testados com a variedade Mundo Novo ao longo dos períodos estudados - experimento 1

Pela Figura 11 verifica-se que para 'Mundo Novo' em espaçamentos largos, a adoção de poda tipo decote a $2 \mathrm{~m}$ de altura, após a sétima colheita, provocou diferenças consideradas significativas em relação ao livre crescimento (sem podas) apenas no segundo ciclo de podas (primeiro ciclo após o decote). As produções médias obtidas foram $1.056,5$ e $830,5 \mathrm{~kg}$ por hectare de café beneficiado respectivamente para os cafeeiros a livre crescimento e os decotados.

Esse decréscimo na produtividade dos cafeeiros decotados pode ser atribuído à diminuição da área produtiva causada pela poda (decote) executada após a sétima safra. Como no período subsequente (terceiro ciclo de podas) as produções não deferiram significativamente, conclui-se que a aplicação de poda do tipo decote provoca redução de produção apenas no período seguinte à sua realização. Contudo, ao adotar essa prática deve-se levar em consideração que ela promove maior facilidade nos tratos culturais $e$ consequentemente maior rendimento da colheita e manejo da lavoura e, em contrapartida, necessita de desbrotas anuais para manter a altura das plantas.

Os resultados mostraram que, para a variedade Mundo Novo, o uso de espaçamentos mais adensados, com a adoção de podas regulares no esquema Beaumont \& Fukunaga é vantajoso até a sétima safra, após a qual as produtividades não são satisfatórias. Tal fato leva a crer que a adoção de plantios em espaçamentos adensados, porém que permitam ser 
transformados em espaçamentos tradicionais, pela eliminação de ruas após as 5 a 7 primeiras safras, ou o uso de recepa total a períodos regulares de 5 a 7 colheitas, sejam tecnologias promissoras para a região.

A variedade Caturra demonstrou menor vigor que 'Mundo Novo' para as condições locais, por apresentar queda de produtividade após 7 safras, mesmo em espaçamentos largos. $O$ uso de recepa total a períodos regulares, talvez seja uma solução para esse problema.

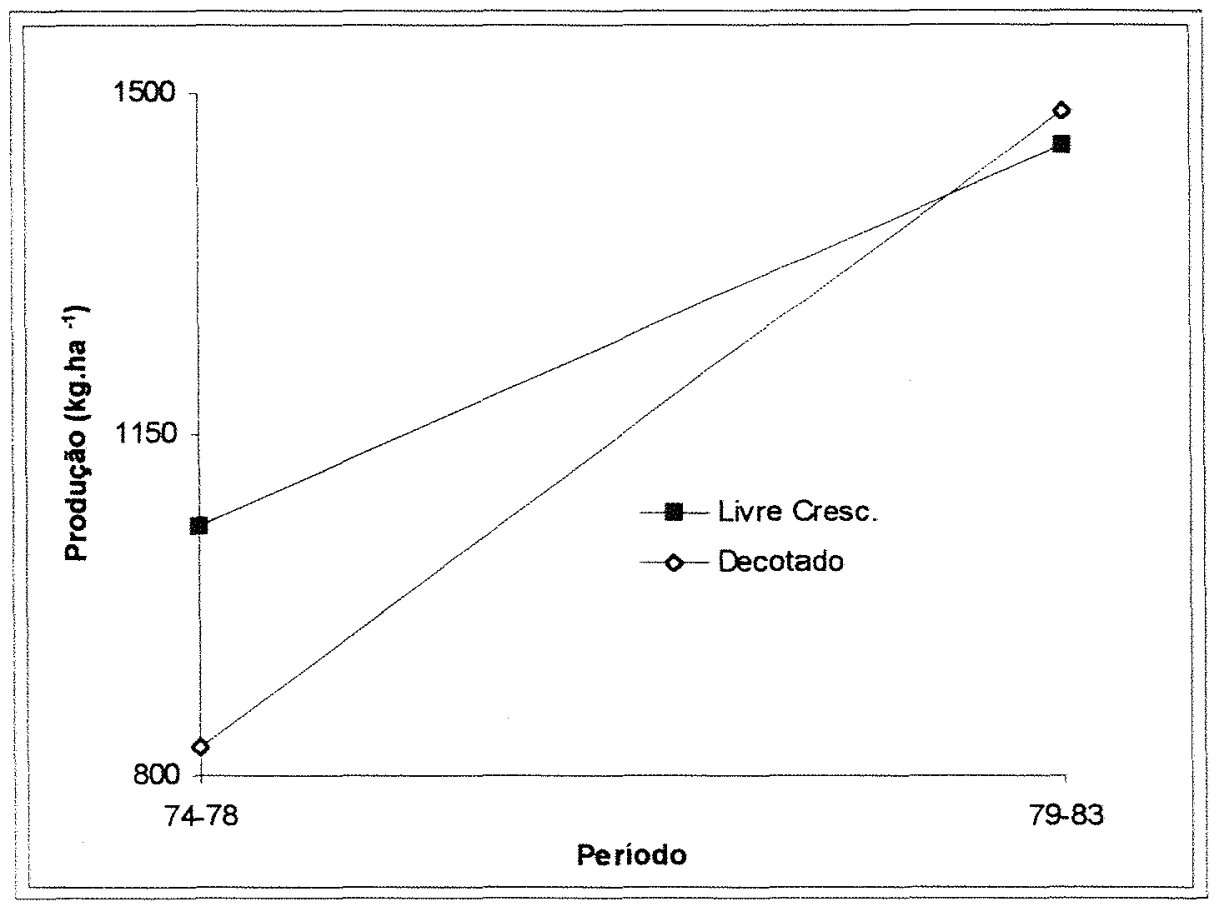

Figura 11: Representação gráfica da produção média de café beneficiado, em kg.ha ${ }^{-1}$, dos sistemas de poda testado no espaçamento não adensado com a variedade Mundo Novo ao longo dos períodos estudados experimento 1

\subsection{Experimento 2}

\subsubsection{Biênio inicial}

Na Tabela 33 é apresentada a análise de variância para os fatores estudados no biênio inicial do experimento 2, com a variedade Mundo Novo. Pelos resultados, verifica-se que apenas o espaçamento apresentou diferenças significativas, seguindo tendência linear. Os dados apresentados na Tabela 34 mostram redução da produtividade com o aumento do espaçamento. Essa redução pode ser bem visualizada na Figura 12, onde verifica-se que a 
produção do espaçamento $2,0 \times 1,0 \mathrm{~m}\left(2 \mathrm{~m}^{2}\right.$ por cova) foi 2,6 vezes superior à produção do espaçamento $3,0 \times 2,0 \mathrm{~m}\left(6 \mathrm{~m}^{2}\right.$ por cova) evidenciando a maximização 'da produção de café nas primeiras colheitas com $o$ adensamento em funçăo da falta de concorrência entre as plantas quando jovens.

Com relação ao número de plantas por cova, não houve significância ao nível de $5 \%$ de probabilidade pelo teste $\mathrm{F}$ e as médias, apresentadas na Tabela 34, mostram uma produção $13 \%$ superior com a adoção de duas plantas por cova.

O valor Tabelado de $\mathrm{F}$ ao nivel de $5 \%$ de probabilidade para 1 grau de liberdade para tratamento e 17 graus de liberdade para o resíduo é de 4,45 (Pimentel Gomes, 1976), próximo do valor calculado 4,31. Assim, a diferença entre os niveis do fator, poderia ser considerado significativo ao nível de $10 \%$ de probabilidade, a favor da adoção de duas plantas.

Tabela 33: Análise da variância do experimento $2 \mathrm{com}$ a variedade Mundo Novo Biênio inicial (1966-1967).

\begin{tabular}{|c|c|c|c|c|}
\hline Fonte de variação & GL & SQ & $\mathbf{Q M}$ & $\mathbf{F}$ \\
\hline Bloco & 1 & 1.770 .361 & 1.770 .361 & \\
\hline Espaçamento(E) & 2 & 16.548.942 & 8.274 .471 & $80,71 \star \star$ \\
\hline Plantas por cova(PC) & 1 & 442.273 & 442.273 & 4,31 \\
\hline$E \times P C$ & 2 & 229.382 & 114.691 & 1,11 \\
\hline Resíduo & 17 & 1.742 .847 & 102.520 & \\
\hline Total & 23 & 20733807 & & \\
\hline
\end{tabular}

Média geral $=2.197,6$

$\mathrm{CV}(\%)=14,57$

** significativo pelo teste $F$ ao nivel de $1 \%$.

Tabela 34: Médias de produção dos tratamentos do experimento $2 \mathrm{com}$ a variedade Mundo Novo, em kg.ha-1 de café beneficiado - Biênio inicial (1966-1967).

\begin{tabular}{|c|c|c|c|}
\hline \multirow[t]{2}{*}{ Espaçamento } & \multicolumn{2}{|c|}{ Plantas por cova } & \multirow[b]{2}{*}{ Média } \\
\hline & 1 planta & 2 plantas & \\
\hline $3,0 \times 2,0 \mathrm{~m}$ & 1.130 & 1.390 & 1.260 \\
\hline $25 \times 15 \mathrm{~m}$ & 1.792 & 2.316 & 2.054 \\
\hline $2.0 \times 1,0 \mathrm{~m}$ & 3.262 & 3.294 & 3.278 \\
\hline Média & 2.061 & 2.333 & 2.197 \\
\hline
\end{tabular}




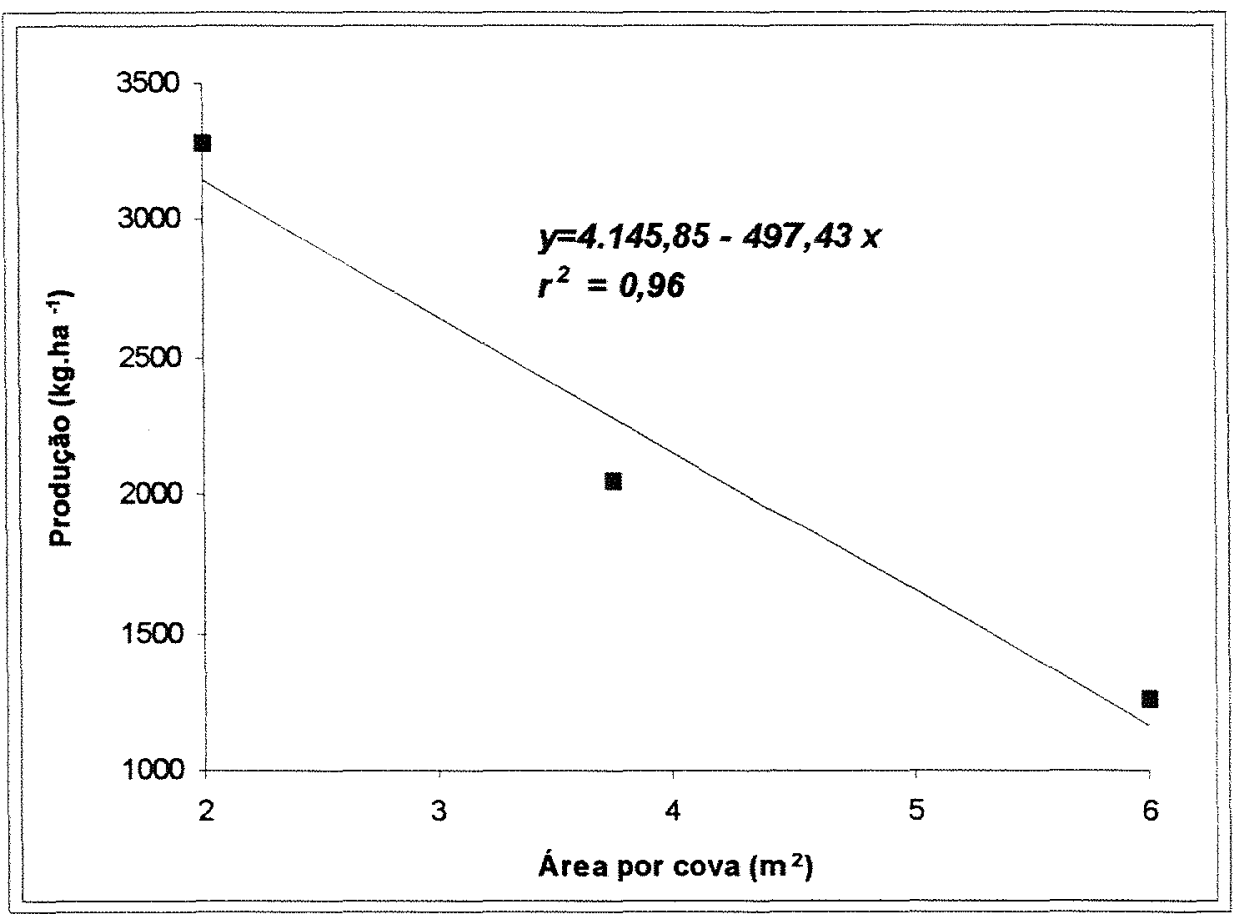

Figura 12: Gráfico da regressão linear entre a produção de café beneficiado variedade Mundo Novo, em kg.ha ${ }^{-1}$, e área por cova no biênio inicial (19671968) do experimento 2

\subsubsection{Primeiro ciclo de podas}

Após a segunda colheita, foram aplicadas as podas nos esquemas pré-determinados para os tratamentos adensados, ou seja: recepa em esquema Beaumont \& Fukunaga a ciclo de cinco anos e recepa de $50 \%$ da parcela em linhas alternadas, sendo podadas três das sete linhas da parcela.

O primeiro ciclo após a aplicação das podas nos espaçamentos adensados, corresponde ao período compreendido entre a $3^{\mathrm{a}}$ e a $7^{\mathrm{a}}$ colheita.

Nesse periodo, o contraste entre o espaçamento de $3,0 \times 2,0 \mathrm{~m}$, propiciando $6 \mathrm{~m}^{2}$ por cova, considerado como largo (não adensado) e os espaçamentos considerados adensados (2,5 $\times 1,5 \mathrm{~m}$ e $2,0 \times 1,0 \mathrm{~m}$ ) não foi significativo, conforme mostra a Tabela 35 . As médias, apresentadas na Tabela 36, calculadas a partir das médias dos tratamentos (Tabela 37), mostram uma produção nos adensados, em média $11 \%$ superior ao não adensado.

O vigor elevado da variedade Mundo Novo, proporciona um desenvolvimento precoce e elevado das plantas, favorecendo a competição entre as covas. Apesar da maior densidade de plantas nos espaçamentos adensados, a produção por planta é reduzida pela competição independente das podas programadas, a tal proporção que a produção por área não diferencia significativamente do espaçamento não adensado (largo), nessa fase da cultura. 
Nos espaçamentos adensados formou-se um fatorial $2 \times 2 \times 2$ entre os niveis $2,0 \times$ $1,0 \mathrm{~m}$ e $2,5 \times 1,5 \mathrm{~m}$ do fator espaçamento, recepa $20 \%$ em esquema Beaumont \& Fukunaga e recepa $50 \%$ alternada do fator tipo de poda e 1 e 2 do fator número de plantas por cova.

Dentre esses fatores o espaçamento e a interação entre o espaçamento e o número de plantas por cova foram significativos pelo teste $F$ ao nivel de 1 e $5 \%$ respectivamente (Tabela 35). O desdobramento do número de plantas por cova nos espaçamentos adensados é apresentado na Tabela 38, onde verifica-se significância do fator nos dois níveis do espaçamento.

As médias desses fatores são descritas na Tabela 39 . O espaçamento $2,0 \times 1,0 \mathrm{~m}$ foi $22 \%$ mais produtivo que o espaçamento $2,5 \times 1,5 \mathrm{~m}$. No entanto a densidade de plantio é $87 \%$ superior (5.000 covas por hectare e 2.667 covas por hectare respectivamente), ressaltando a diminuição da produção por cova com o adensamento do plantio.

Por sua vez, o número de plantas por cova teve comportamento diferenciado nos dois espaçamentos. Considerando-se o espaçamento $2,5 \times 1,5 \mathrm{~m}$ houve uma maior produção com a adoção de duas plantas por cova, enquanto no espaçamento $2,0 \times 1,0 \mathrm{~m}, 0$ uso de apenas uma planta por cova mostrou-se mais produtivo, conforme pode ser observado na Tabela 39.

Esses resultados demonstram novamente para 'Mundo Novo' maior competição promovida entre plantas quanto maior o adensamento. Para um mesmo número de covas por área, a produção foi substancialmente inferior (26\%) que a adoção de apenas uma muda por cova.

O tipo de poda adotada e as demais interações estudadas para os espaçamentos adensados não foram significativos, conforme mostra a Tabela 38 e as médias são descritas na Tabela 40. Neste caso, quando da adoção de plantio adensado com a variedade 'Mundo Novo', a utilização de recepa em $50 \%$ das linhas, de forma alternada, em apenas uma época parece ser mais favorável que a adoção do esquema Beaumont \& Fukunaga. Além de apresentar uma diferença de produção não significativa em relação ao sistema Baeumont \& Fukunaga, o seu manejo e aplicação é substancialmente mais simples, principalmente em grandes extensões.

Quando utilizou-se o espaçamento largo $(3,0 \times 2,0 \mathrm{~m})$ o único fator apresentado até esse período era o número de plantas por cova nos níveis 1 e 2 os quais não apresentaram diferenças significativas (Tabela 38). As suas médias estão representadas na Tabela 40.

Considerando que a produção não apresentou diferenças significativas entre os níveis do fator e o custo de plantio, a adoção de uma planta por cova apresenta-se como mais vantajosa. 
Tabela 35: Análise da variância do experimento 2 com variedade Mundo Novo Primeiro ciclo de podas (1968-1972).

\begin{tabular}{|c|c|c|c|c|c|}
\hline Fonte de variação & GL & SQ & QM & $\mathbf{F}$ & \\
\hline Bloco & 1 & 14.701 & 14.701 & & \\
\hline (tratamento) & (11) & $(2.278 .686)$ & (207.153) & $(2,72)$ & * \\
\hline Largo vs Adensado & 1 & 332.001 & 332.001 & 4,36 & \\
\hline (dentro de adensado) & (7) & $(1720.646)$ & (245.806) & $(3,23)$ & * \\
\hline Espaçamento(E) & 1 & 1.000 .000 & 1.000 .000 & 13,15 & ** \\
\hline Tipo de poda(TP) & 1 & 15.876 & 15.876 & 0,20 & \\
\hline Plantas por cova(PC) & 1 & 85.264 & 85.264 & 1,12 & \\
\hline ExTP & 1 & 68.121 & 68.121 & 0,89 & \\
\hline$E \times P C$ & 1 & 505.521 & 505.521 & 6,64 & \\
\hline $\mathrm{TP} \times \mathrm{PC}$ & 1 & 38.809 & 38.809 & 0,51 & \\
\hline$E \times T P \times P C$ & 1 & 7.056 & 7.056 & 0,09 & \\
\hline (dentro de largo) & (3) & $(226.037)$ & (75.345) & $(0,99)$ & \\
\hline Plantas por cova(PC) & 1 & 183.012 & 183.012 & 2,40 & \\
\hline desvios & 2 & 43.024 & 21.512 & 2,28 & \\
\hline Resíduo & 11 & 836.476 & 76.043 & & \\
\hline Total & 23 & 3.129 .863 & & & \\
\hline $\begin{array}{l}\text { Média geral }=2.453,1 \\
C V(\%)=11,24\end{array}$ & & & & & \\
\hline
\end{tabular}

Tabela 36: Médias de produção, em kg.ha ${ }^{-1}$ de café beneficiado, em função do tipo de plantio e número de plantas por cova, com a variedade Mundo Novo, no experimento 2 - Primeiro ciclo de podas (1968-1972).

\begin{tabular}{ccc}
\hline \multirow{2}{*}{ Plantas por cova } & \multicolumn{2}{c}{ Tipo de plantio } \\
\cline { 2 - 3 } & Largo & Adensado \\
\hline 1 & 2.135 & 2.609 \\
2 & 2.438 & 2.463 \\
\hline Média & 2.286 & 2.536 \\
\hline
\end{tabular}

Tabela 37: Médias de produção dos tratamentos do experimento 2 com a variedade Mundo Novo, em kg.ha ${ }^{-1}$ de café beneficiado Primeiro ciclo de podas (1968-1972).

\begin{tabular}{llcc}
\hline Espaçamento & Tipo de Poda & \multicolumn{2}{c}{ Planta por cova } \\
\cline { 3 - 4 } & & 1 planta & 2 plantas \\
\hline $3,0 \times 2,0 \mathrm{~m}$ & Livre crescim. & 2.135 & 2.438 \\
$2,5 \times 1,5 \mathrm{~m}$ & Recepa BF & 2.187 & 2.453 \\
$2,5 \times 1,5 \mathrm{~m}$ & Recepa $50 \%$ & 2.176 & 2.329 \\
$2,0 \times 1,0 \mathrm{~m}$ & Recepa BF & 2.870 & 2.509 \\
$2,0 \times 1,0 \mathrm{~m}$ & Recepa $50 \%$ & 3.204 & 2.562 \\
\hline Média & & 2.451 & 2.454 \\
\hline
\end{tabular}


Tabela 38: Análise da variância do desdobramento da interação Espaçamento $x$ Plantas por cova com a variedade Mundo Novo no experimento 2, - Primeiro ciclo de podas (1968-1972).

\begin{tabular}{lcrrr}
\hline \multicolumn{1}{c}{ Fonte de variação } & GL & \multicolumn{1}{c}{ SQ } & \multicolumn{1}{c}{ QM } & \multicolumn{1}{c}{ F } \\
\hline Bloco & 1 & 14.701 & 14.701 & \\
(tratamento) & $(11)$ & $(2.278 .686)$ & $(207.153)$ & $(2,72) *$ \\
Largo vs Adensado & 1 & 332.001 & 332.001 & $4,36 *$ \\
(dentro de adensado) & $(7)$ & $(1.720 .646)$ & $(245.806)$ & $(3,23)^{*}$ \\
Espaçamento(E) & 1 & 1.000 .000 & 1.000 .000 & $13,15 *$ \\
Tipo de poda(TP) & 1 & 15.876 & 15.876 & 0,20 \\
PC em E=2,5 x 1,5 m & 1 & 87.780 & 87.780 & $1,15 *$ \\
PC em E= 2,0 x 1,0 m & 1 & 503.004 & 503.004 & $6,61 *$ \\
Ex TP & 1 & 68.121 & 68.121 & 0,89 \\
TP x PC & 1 & 38.809 & 38.809 & 0,51 \\
Ex TP x PC & 1 & 7.056 & 7.056 & 0,09 \\
(dentro de largo) & $(3)$ & $(226.037)$ & $(75.345)$ & $(0,99)$ \\
Plantas por cova(PC) & 1 & 183.012 & 183.012 & 2,40 \\
desvios & 2 & 43.024 & 21.512 & 0,28 \\
Residuo & 11 & 836.476 & 76.043 & \\
\hline Total & 23 & 3.129 .863 & & \\
\hline
\end{tabular}

Média geral $=2.453,1$

$\mathrm{CV}(\%)=11,24$

* significativo pelo teste $F$ ao nível de $5 \%$; ${ }^{\text {* }}$ significativo pelo teste $F$ ao nivel de $1 \%$.

Tabela 39: Médias de produção, dos espaçamentos adensados do experimento 2 com a variedade Mundo Novo em kg.ha ${ }^{-1}$ de café beneficiado - Primeiro ciclo de podas (1968-1972).

\begin{tabular}{|c|c|c|c|}
\hline \multirow[b]{2}{*}{ Espaçamento } & \multicolumn{2}{|c|}{ Plantas por cova } & \multirow[b]{2}{*}{ Média } \\
\hline & 1 & 2 & \\
\hline $2,5 \times 1,5 \mathrm{~m}$ & 2.181 & 2.391 & 2.286 \\
\hline $2,0 \times 1,0 \mathrm{~m}$ & 3.037 & 2.535 & 2.786 \\
\hline Média & 2.609 & 2.463 & 2.536 \\
\hline
\end{tabular}

Tabela 40: Médias de produção em função do tipos de poda, dos espaçamentos e número de plantas por cova com a variedade Mundo Novo, em kg.ha ${ }^{-1}$ de café beneficiado no experimento 2, - Primeiro ciclo de podas (1968-1972).

\begin{tabular}{lccc}
\hline & \multicolumn{3}{c}{ Tipo de poda } \\
\cline { 2 - 4 } Espaçamento & Livre cresc. & Recepa BF & Recepa 50\% \\
\hline $3,0 \times 2,0 \mathrm{~m}$ & 2.287 & 2.320 & 2.252 \\
$2,5 \times 1,5 \mathrm{~m}$ & & 2.689 & 2.883 \\
$2,0 \times 1,0 \mathrm{~m}$ & & & \\
Plantas por cova. & & 2.528 & 2.690 \\
1 & 2.135 & 2.481 & 2.445 \\
\hline 2 & 2.438 & 2.504 & 2.567 \\
\hline Média & 2.286 & & \\
\hline
\end{tabular}




\subsubsection{Segundo ciclo de podas}

Pelos resultados da análise para o segundo ciclo de podas, correspondendo da $8^{\mathrm{a}}$ à $12^{\mathrm{a}}$ colheita, é possível verificar que o contraste entre o espaçamento largo e os espaçamentos adensados foi significativo (Tabela 41). Os valores médios, apresentadas na Tabela 42 , demonstram que o espaçamento largo foi mais produtivo que os espaçamentos adensados, evidenciando a competição entre as plantas, apesar das podas aplicadas nessa fase da cultura.

Quando se considera o fatorial formado dentro dos espaçamentos adensados, verificase que apenas o número de plantas por cova apresentou diferenças significativas. As produções médias dos tratamentos são apresentados na Tabela 43. As médias dos fatores principais e das interações são descritas nas Tabelas 44 e 45.

Nessa fase, a utilização de uma planta por cova foi significativamente superior à adoção de duas plantas por cova nos espaçamentos adensados (Tabela 41). Esses resultados evidenciam a maior competição entre as plantas, depreciando a produção, com o envelhecimento da cultura.

Com relação ao sistema de podas, após a sétima colheita, os tratamentos em esquema pré-determinado Beaumont \& Fukunaga iniciaram o segundo ciclo de podas e os tratamentos que foram recepados em ruas alternadas (50\%) após a segunda colheita, foram podadas com recepa baixa em todas as linhas $(100 \%)$ após a sétima safra.

Durante 0 segundo ciclo de podas ( $8^{\mathrm{a}}$ a $12^{\mathrm{a}}$ colheita) não foi constatada diferença significativa com relação à produção entre os dois sistemas de poda acima descritos. Logo, sendo a recepa total menos trabalhosa que em esquema Beaumont \& Fukunaga, essa se torna a opção mais vantajosa, apesar de não diferir na produção.

Também após a sétima safra, o espaçamento largo $(3,0 \times 2,0 \mathrm{~m})$ foi dividido em dois sistemas de podas, livre crescimento (sem podas) e decotado a $2 \mathrm{~m}$ de altura.

Pela Tabela 41, é possível verificar que não houve diferenças significativas entre esses dois tipos de condução dos cafeeiros no espaçamento não adensado (largo), nem para a interação entre a condução dos cafeeiros e número de plantas por cova. Os valores das produções médias dos dois sistemas são apresentados na Tabela 45.

Apesar de não diferirem significativamente quanto à produção, pela diminuição do porte da planta, o decote favorece os tratos culturais, principalmente a colheita. Por outro lado, requer desbrotas permanentes para a manutenção da altura das plantas e esses fatores devem ser considerados para uma tomada de decisão quanto à sua aplicação.

O número de plantas por cova foi significativo ao nivel de $5 \%$ de probabilidade, no espaçamento largo (Tabela 41). Os valores médios de produção apresentados na Tabela 42 , 
demonstram uma produção mais elevada com a adoção de duas plantas por cova, nessa fase da cultura.

Tabela 41: Análise da variância do experimento $2 \mathrm{com}$ a variedade Mundo Novo Segundo ciclo de podas (1973-1977).

\begin{tabular}{lcrrr}
\hline \multicolumn{1}{c}{ Fonte de variação } & GL & \multicolumn{1}{c}{ SQ } & \multicolumn{1}{c}{ QM } & \multicolumn{1}{c}{ F } \\
\hline Bloco & 1 & 132.313 & 132.313 & \\
(tratamento) & $(11)$ & $(1.262 .785)$ & $(114.798)$ & $(4,79)$ \\
Largo vs Adensado & 1 & 733.095 & 733.095 & 30,58 \\
(dentro de adensado) & $(7)$ & $(238.820)$ & $(34.117)$ & $(1,42)$ \\
$\quad$ Espaçamento(E) & 1 & 8.649 & 8.649 & 0,36 \\
$\quad$ Tipo de poda(TP) & 1 & 43.681 & 43.681 & 1,82 \\
Plantas por cova(PC) & 1 & 153.664 & 153.664 & 6,41 \\
Ex TP & 1 & 26.896 & 26.896 & 1,12 \\
Ex PC & 1 & 1.225 & 1.225 & 0,05 \\
TP X PC & 1 & 2.401 & 2.401 & 0,10 \\
Ex TP x PC & 1 & 2.304 & 2.304 & 0,09 \\
(dentro de largo) & $(3)$ & $(290.869)$ & $(96.956)$ & $(4,04)$ \\
Tipo de poda(TP) & 1 & 47.124 & 47.124 & 1,96 \\
Plantas por cova(PC) & 1 & 237.360 & 237.360 & 9,90 \\
TP x PC & 1 & 6.384 & 6.384 & 0,26 \\
Resíduo & 11 & 263.624 & 23.965 & \\
\hline Total & 23 & 1.658 .723 & & \\
\hline
\end{tabular}

Média geral $=1.268,58$

$\mathrm{CV}(\%)=12,20$

* significativo pelo teste $\mathrm{F}$ ao nível de $5 \%$; ${ }^{\star \star}$ significativo pelo teste $\mathrm{F}$ ao nível de $1 \%$.

Tabela 42: Médias de produção, em função do tipo de plantio e número de plantas por cova com a variedade Mundo Novo em $\mathrm{kg} \mathrm{ha}^{-1}$ de café beneficiado no experimento 2, - Segundo ciclo de podas (1973-1977).

\begin{tabular}{ccc}
\hline \multirow{2}{*}{ Plantas por cova } & \multicolumn{2}{c}{ Tipo de plantio } \\
\cline { 2 - 3 } & Largo & Adensado \\
\hline 1 & 1.343 & 1.243 \\
2 & 1.688 & 1.047 \\
\hline Média & 1.515 & 1.145 \\
\hline
\end{tabular}

Tabela 43: Médias de produção dos tratamentos do experimento 2 com a variedade Mundo Novo, em kg.ha- ${ }^{-1}$ de café beneficiado Segundo ciclo de podas (1973-1977).

\begin{tabular}{llcc}
\hline Espaçamento & Tipo de Poda & \multicolumn{2}{c}{ Planta por cova } \\
& & 1 planta & 2 plantas \\
\hline $3,0 \times 2,0 \mathrm{~m}$ & Livre crescim. & 1.295 & 1.583 \\
$3,0 \times 2,0 \mathrm{~m}$ & Decote & 1.392 & 1.793 \\
$2,5 \times 1,5 \mathrm{~m}$ & Recepa BF & 1.224 & 997 \\
$2,5 \times 1,5 \mathrm{~m}$ & Recepa 100\% & 1.198 & 1.068 \\
$2,0 \times 1,0 \mathrm{~m}$ & Recepa BF & 1.182 & 968 \\
$2,0 \times 1,0 \mathrm{~m}$ & Recepa 100\% & 1.368 & 1.155 \\
\hline Média & & 1.276 & 1.260 \\
\hline
\end{tabular}


Tabela 44: Médias de produção dos espaçamentos adensados com a variedade Mundo Novo do experimento 2 , em kg.ha ${ }^{-1}$ de café beneficiado - Segundo ciclo de podas (1968-1972).

\begin{tabular}{|c|c|c|c|}
\hline \multirow[b]{2}{*}{ Espaçamento } & \multicolumn{2}{|c|}{ Plantas por cova } & \multirow[b]{2}{*}{ Média } \\
\hline & 1 & 2 & \\
\hline $2,5 \times 1,5 \mathrm{~m}$ & 1.211 & 1.032 & 1.121 \\
\hline $2,0 \times 1,0 \mathrm{~m}$ & 1.275 & 1.061 & 1.168 \\
\hline Média & 1.243 & 1.047 & 1.145 \\
\hline
\end{tabular}

Tabela 45: Médias de produção dos espaçamentos, tipos de poda e número de plantas por cova com a variedade Mundo Novo no experimento 2 , em kg.ha- ${ }^{-1}$ de café beneficiado - Segundo ciclo de podas (1973-1977).

\begin{tabular}{lcccc}
\hline & \multicolumn{4}{c}{ Tipo de poda } \\
\cline { 2 - 5 } Espacamento & Livre cresc. & Decote & Recepa BF & Recepa 100\% \\
\hline $3,0 \times 2,0 \mathrm{~m}$ & 1.439 & 1.592 & & \\
$2,5 \times 1,5 \mathrm{~m}$ & & & 1.110 & 1.133 \\
$2,0 \times 1,0 \mathrm{~m}$ & & & 1.075 & 1.261 \\
Plantas por cova & & & & \\
1 & 1.295 & 1.392 & 1.203 & 1.283 \\
2 & 1.583 & 1.793 & 982 & 1.111 \\
\hline Média & 1.439 & 1.592 & 1.092 & 1.197 \\
\hline
\end{tabular}

\subsubsection{Variação dos fatores ao longo dos periodos}

Pelo demonstrado na Figura 13, a produção inicial é amplamente incrementada com a diminuição do espaçamento. Todavia, com o decorrer dos períodos, há uma pronunciada queda da produção no espaçamento $2,0 \times 1,0 \mathrm{~m}$; já no espaçamento $2,5 \times 1,5$ a produção do primeiro ciclo de podas foi próxima da produção do biênio inicial e apresentou acentuada queda no período seguinte (segundo ciclo de podas). No espaçamento $3,0 \times 2,0 \mathrm{~m}$ a produção aumentou entre o biênio inicial e o primeiro ciclo de podas apresentando uma queda na produtividade do período subsequente. Entretanto, essa queda é menos pronunciada que nos espaçamentos adensados e a produção nesse período é maior no espaçamento largo.

A competição entre as plantas nos espaçamentos adensados pode explicar a queda acentuada na produção dos espaçamentos adensados ao longo dos períodos, conforme demonstrado na Figura 14. Por outro lado, a produção aumenta no espaçamento não adensado entre o biênio inicial e o primeiro ciclo de podas.

O efeito da competição entre as covas fica bem demonstrado na Figura 13. Com a maior densidade de plantio, a competição entre as plantas intensifica logo após o biênio inicial, afetando drasticamente a produção, acentuando seu efeito no segundo ciclo de podas. No espaçamento $2,5 \times 1,5 \mathrm{~m}$ essa competição também pode ser detectada após o biênio inicial, 
tendo em vista que a produção no primeiro ciclo de podas foi semelhante ao do biênio inicial, apesar do maior desenvolvimento da cultura. No entanto, essa competição é menos pronunciada que no espaçamento $2,0 \times 1,0 \mathrm{~m}$.

Quando se considera o espaçamento largo, verifica-se que a competição entre as plantas ainda não se pronuncia até o primeiro ciclo de podas, já que a produção é incrementada entre o biênio inicial e o primeiro ciclo, só decrescendo de forma menos acentuada entre o primeiro e o segundo ciclo de podas.

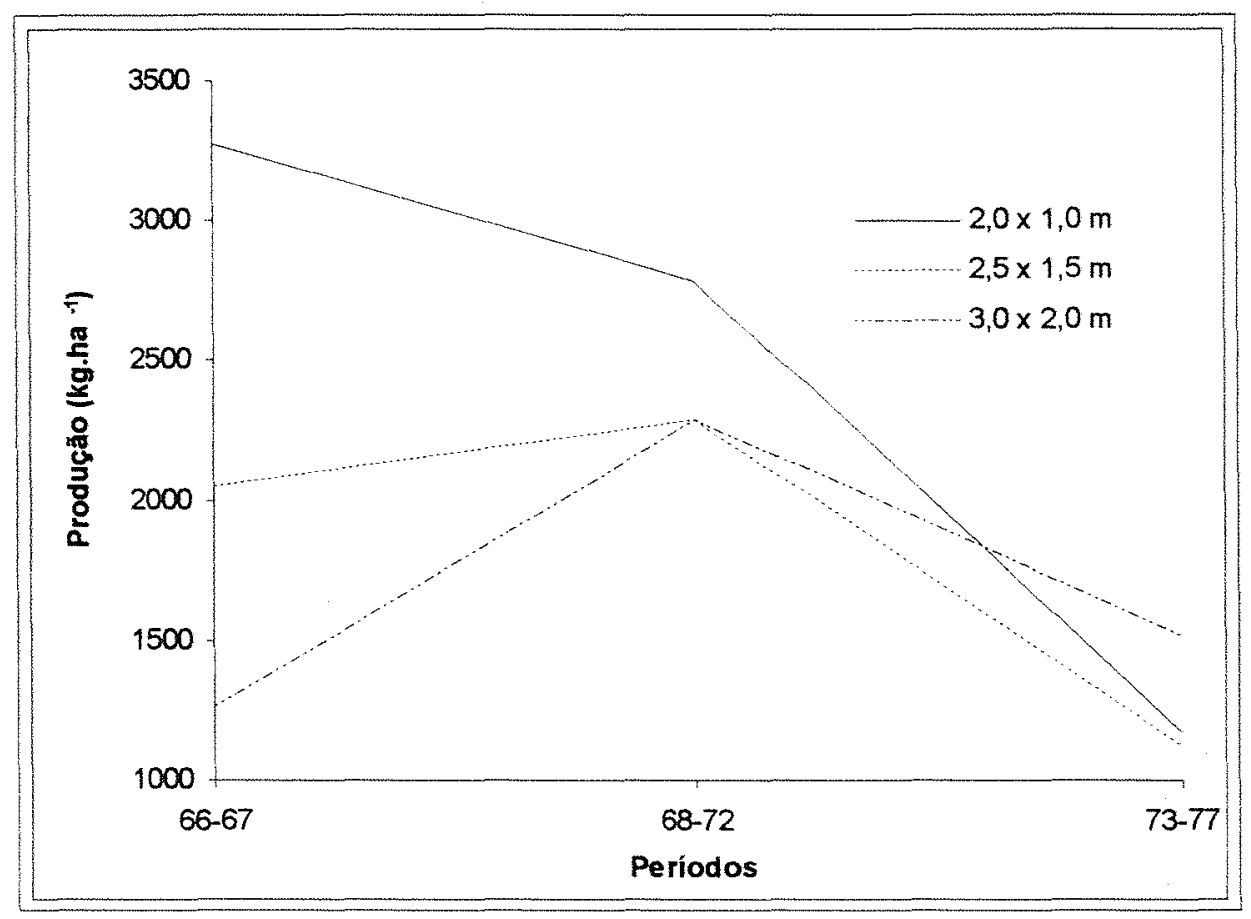

Figura 13: Representação gráfica da produção média de café beneficiado, em kg.ha ${ }^{-1}$, dos espaçamentos testados ao longo dos períodos estudados com a variedade Mundo Novo - experimento 2 


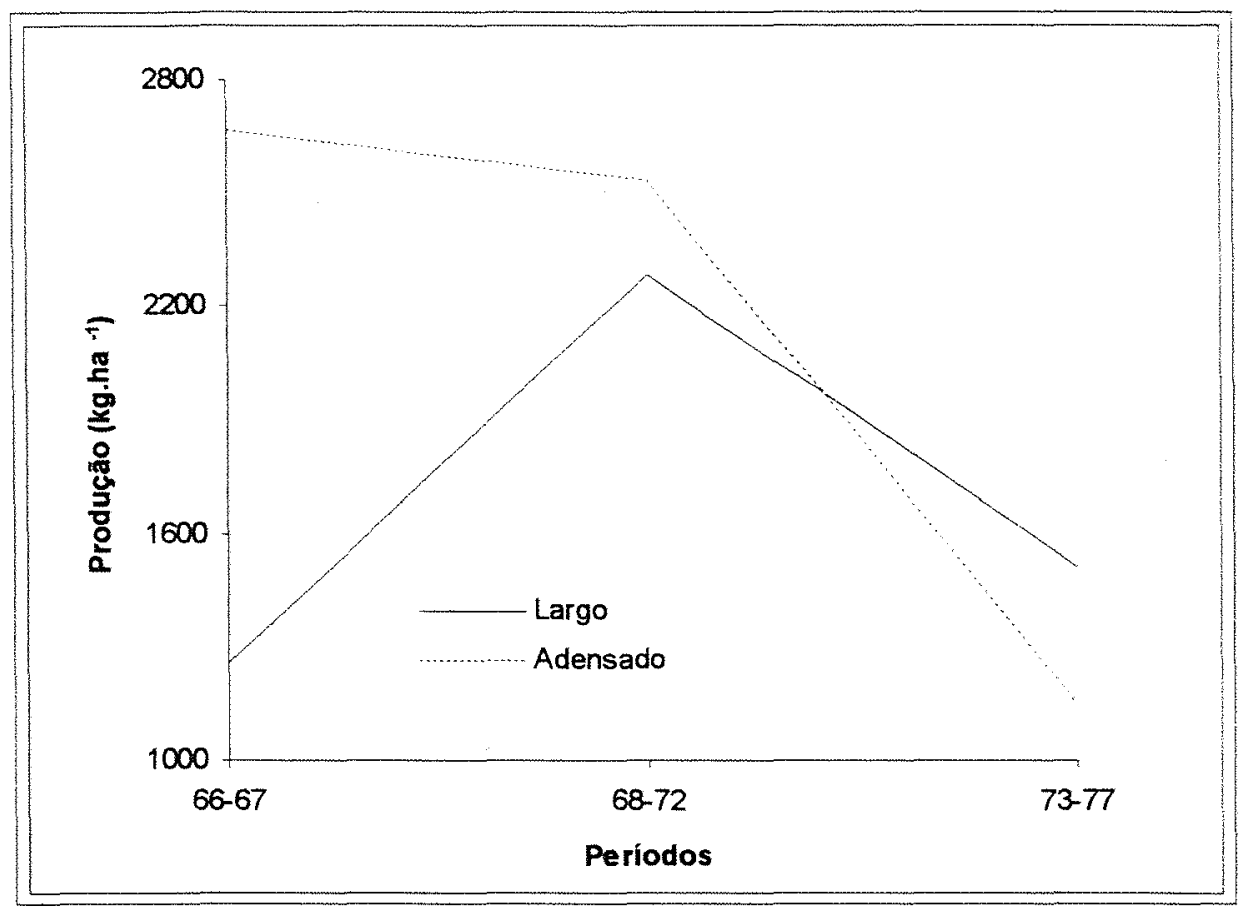

Figura 14: Representação gráfica da produção média de café beneficiado, em kg.ha ${ }^{-1}$, dos sistemas de plantio testados ao longo dos períodos estudados com a variedade Mundo Novo - experimento 2

Em virtude da variedade Mundo Novo apresentar excelente vigor, porte e área foliar elevados, a competição entre as plantas nos espaçamentos adensados se expressa de forma mais acentuada em relação ao espaçamento largo, apesar das podas adotadas que não foram significativas em nenhum dos períodos estudados, tanto aplicada em todos os espaçamentos.

Com relação aos resultados do número de plantas por cova (Figura 15) verifica-se uma inversão de comportamento entre o biênio inicial e o primeiro ciclo de podas, nos espaçamentos adensados. Com duas plantas por cova há uma queda na produção entre os períodos, enquanto há aumento na produção com uma planta por cova, evidenciando a competição mais precoce na medida do aumento da densidade de cafeeiros.

Essa competição se iguala após o primeiro ciclo de podas e a queda de produção é proporcional e semelhante entre o primeiro e segundo ciclo de podas, tanto para uma quanto para duas plantas por cova.

No espaçamento largo $(3,0 \times 2,0 \mathrm{~m})$, a tendência manteve-se a mesma ao longo dos períodos, tanto para a adoção de uma quanto para duas plantas por cova, conforme pode ser observado na Figura 16, evidenciando a maior produção com duas plantas sem caracterizar competição entre plantas na comunidade. 


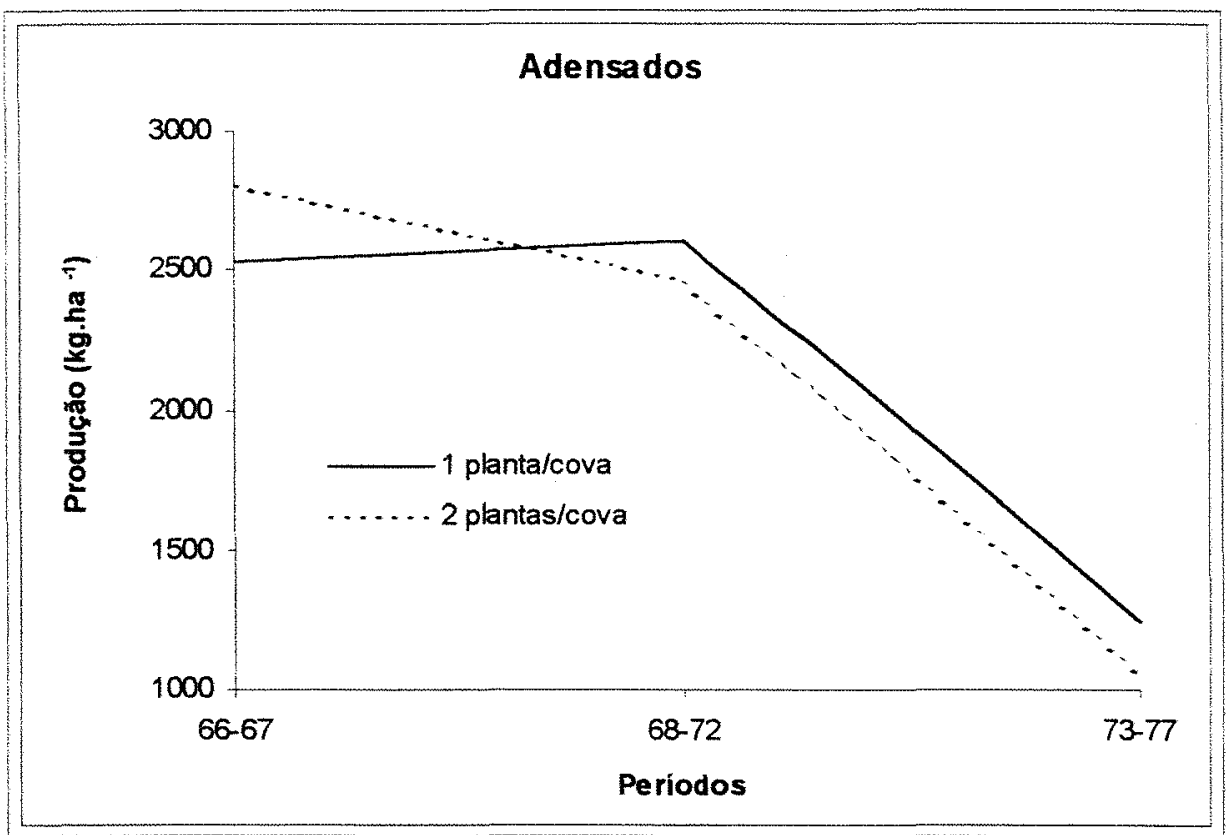

Figura 15: Representação gráfica da produção média de café beneficiado, em kg.ha ${ }^{-1}$, com o plantio de 1 ou 2 plantas por cova nos espaçamentos adensados ao longo dos períodos estudados com a variedade Mundo Novo Experimento 2

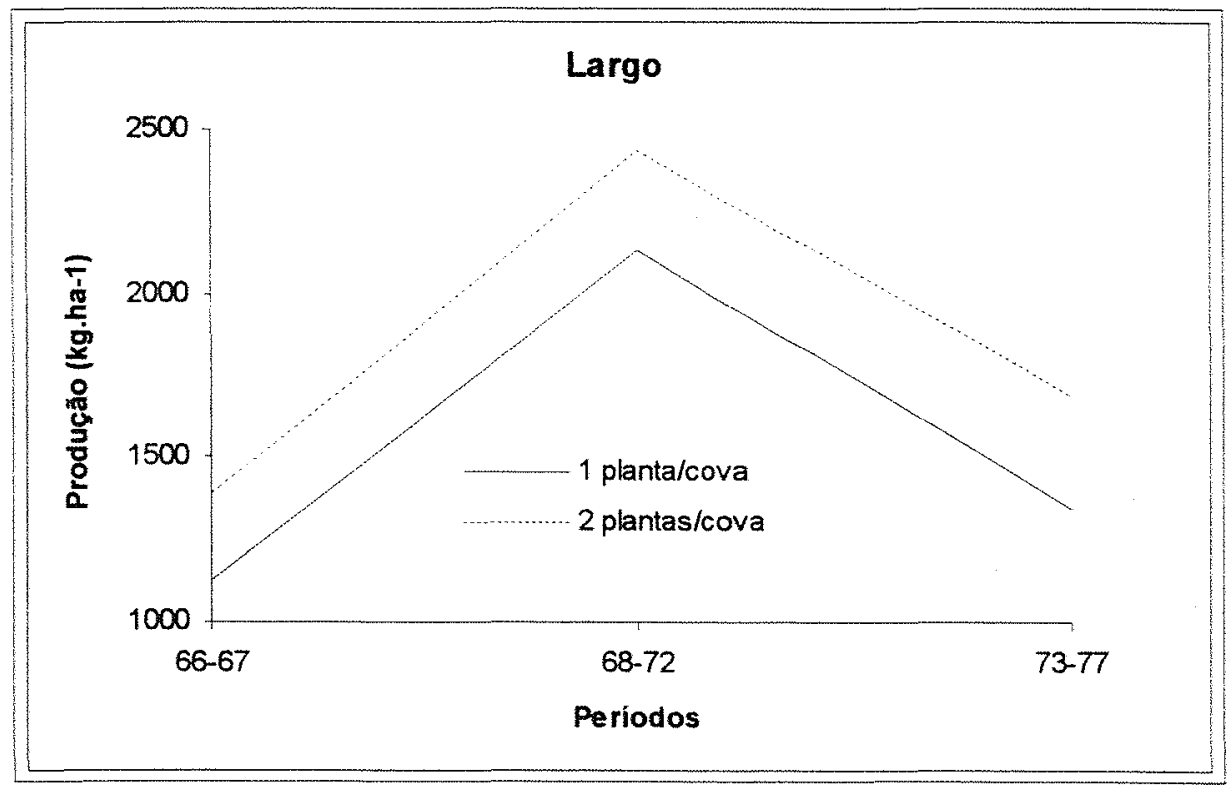

Figura 16: Representação gráfica da produção média de café beneficiado em kg.ha ${ }^{-1}$, com o plantio de 1 ou 2 plantas por cova no espaçamento largo ao longo dos períodos estudados, com a variedade Mundo Novo . Experimento 2. 


\section{CONCLUSÕES}

Em face dos resultados obtidos, para as condições dos experimentos, pode-se concluir que:

1. O aumento da densidade de plantio pela diminuição da área ocupada por cova propiciou aumento de produção apenas nas duas primeiras safras para a variedade Mundo Novo;

2. Na variedade Caturra o aumento da densidade de plantas, pela diminuição da área ocupada por cova e pelo aumento do número de plantas por cova, propiciou aumento de produção durante as sete primeiras colheitas ( biênio inicial e primeiro ciclo de podas);

3. O aumento da densidade populacional tornou-se prejudicial à produção após 12 e 7 colheitas para as variedades Caturra e Mundo Novo, respectivamente;

4. Independentemente das densidades de plantio estudadas, a variedade Caturra apresentou acentuado decréscimo na produção após sete colheitas;

5. A variedade Mundo Novo manteve a capacidade produtiva ao longo do período;

6. A condução do cafezal com podas programadas no sistema Beaumont \& Fukunaga em ciclos de 5 anos, não se mostrou adequado às condições da região;

7. A adoção de poda tipo decote após sete colheitas, para a variedade Mundo Novo, não provocou alteração na produção em relação ao livre crescimento;

8. Para a variedade 'Mundo Novo' a adoção de 2 plantas por cova, aumentou a produção apenas na menor densidade de plantio e no último ciclo de podas estudado ( $8^{\mathrm{a}}$ a $12^{\mathrm{a}}$ colheita);

9. Para a variedade Mundo Novo, o espaçamento $2,0 \times 1,0 \mathrm{~m}$ a melhor disposição foi a utilização de uma planta por cova, enquanto no espaçamento $3,0 \times 2$, de duas;

10. Os espaçamentos adensados para 'Mundo Novo' aumentaram a produção inicial da cultura, sendo prejudicial a sua utilização a longo prazo;

11.A utilização de recepa, tanto em esquema pré-determinado Beaumont \& Fukunaga, quanto recepa em ruas alternadas ou área total não favoreceram ao aumento da produção nos plantios adensados para a variedade Mundo Novo;

12.0 esquema de podas Beaumont \& Fukunaga não apresentou diferenças significativas em relação à recepa em ruas alternadas ou a recepa total em espaçamentos adensados com a variedade Mundo Novo; 
13. Constatou-se queda na produtividade dos plantios adensados de 'Caturra' e 'Mundo Novo com o decorrer das colheitas, mesmo com intervenção por podas;

14.Para as variedades Caturra e Mundo Novo, os plantios não adensados são mais adequados a uma produção de café de longo prazo. 


\section{REFERÊNCIAS BIBLIOGRÁFICAS}

ALMEIDA, S.R.; MATIELLO, J.B.; MIGUEL, A.E. Estudo de diversas modalidades de plantio concentrado em relação ao plantio tradicional do cafeeiro cultivar Mundo Novo, no sulde Minas. In: CONGRESSO BRASILEIRO DE PESQUISAS CAFEEIRAS, 10, Poços de Caldas, 1993. Anais. Rio de Janeiro: IBC, 1983. p.308-310

ANDROCIOLI FILHO, A. Procedimentos para o adensamento de plantio e contribuição para o aumento da produtividade. In: SIMPÓSIO INTERNACIONAL SOBRE CAFÉ ADENSADO. Londrina, 1994. Anais. Londrina: IAPAR, 1994. p.251-275.

ANDROCIOLI FILHO, A.; SIQUEIRA, R. Odiâmetro da saia do cafeeiro como critério para ajuste de espaçamento. In: CONGRESSO BRASILEIRO DE PESQUISAS CAFEEIRAS, 19, Três Pontas, 1993. Resumos. Rio de Janeiro: MAARA/PROCAFE, 1993. p.16-17.

BACHA,C.J.C. Ciclos e tendências do café no Brasil. Preços Agrícolas. n. 117, p. 2-5. 1996.

BARROS, I. de. Alerta sobre o café adensado. Folha de São Paulo. Agrofolha, São Paulo, 26 de julho de 1994. p.64.

BEAUMONT, J.H.; FUKUNAGA, E.T. Factors affecting the growth and yield of coffee in Kona. Kona: Hawaii Agricultural Experiment Station, Bulletin 113. 39p. 1958.

BELLAVITA, M.O. Rentabilidade de la exploración del café al sol. Agronomia Tropical. v. 18, $n^{\circ} 2$, p.283-292. 1968.

BERNARDES, M.S. Fotossíntese no dossel das plantas cultivadas. In: CASTRO, P.R.C.; FERREIRA, S.O.; YAMADA, T. (eds.). Ecofisiologia da produção agricola. Piracicaba: POTAFÓS, 1987. p.12-48.

BERTONE,M.V.F. Anotações sobre o Acordo Internacional do Café. Garça: Cooperativa dos Cafeicultores de Garça (GARCAFÉ), 1992. 35p.

BETTENCOURT, A.J.; RODRIGUEZ JÚNIOR, C.J. Principles and practice of coffee breeding for resistance to rust and other diseases. In: CLARKE, R.J.; MACKAE, R. eds. Coffee. London: Elsevier Applied Science, 1988. p.199-234, v. 4.

BOCQUET, M. Quelques considerations sur la densité et le dispositif de plantation a adapter pour le caféier Robusta. Café, Cacao, Thé. v. 2, n 3, p.111-118. 1958. 
BOSQUE, L.R.; PEREZ, P.R.; RODRIGUEZ, S.J. Distancia más apropriada para la siembra del café. Agricultura al Dia. v. $9, n^{\circ} 5$, p.21. 1962.

BROWNING, G.; FISHER, N.M. High density coffee: yield results for the first cycle from systematic plant spacing designs. Kenya Coffee. v. 41, p.209-217. 1976.

CAMARGO, A.P.; DANTAS, F.A.S.; MATIELLO, J.B.; SANTINATO, R. Influência de espaçamento entre linhas e entre covas de café cultivar Catuaí, nas condições de BrejãoPE. In: CONGRESSO BRASILEIRO DE PESQUISAS CAFEEIRAS, 16, Espírito Santo do Pinhal, 1990. Resumos. Rio de Janeiro: IBC, 1990. p.122-123.

CANNELL, M.G.R. Effect of irrigation, mulch and $\mathrm{N}$-fertilizer on yield components of arabica coffee. Exploratory Agriculture. v. 9, p.225-232. 1973.

CANNELL, M.G.R. Factors affecting arabica coffee beans size in Kenya. Kenya Coffee. v. 13, p.343-352, 1974.

CANNELL, M.G.R. Primary production, fruit production and assimilate partition in arabica coffee: A review. Annual Repport of Coffee Research Station. p.6-24. 1972.

CANNELL, M.G.R. Crop physiological aspects of coffee bean yield. Kenya Coffee. v. 41, p.245253, 1976.

CANNEL, M.G.R. Physiology of the coffee crop. In: CLIFFORD, M.N.; WILLSON, K.C. (ed.). Coffee: botany biochemistry and production of beans and beverage. Croom Beckenham: Helm, 1985. p.108-134.

CAMPOS, H. Estatística aplicada à experimentação com cana-de-açúcar. Piracicaba: FEALQ. 1984. 292p.

CAPOT, J. L'melioration du cafeier en lote d'Ivoire. Les hybrids "Arabusta". Café, Cacao, Thé. v. $16, n^{\circ} 1$, p.3-18. 1972.

CARVAJAL, J.F. Manejo das plantações de café na América Central. In: mLAVOLTA, E.; YAMADA, T.; GUIDOLIN, J.A. (eds.). Nutrição e adubação do cafeeiro. Piracicaba: POTAFÓS. 1981, p.195-212.

CARVAJAL, J.F. Cafeto: cultivo y fertilización. Berna: Instituto Internacional de la Potarsa, 1984. 254p.

CARVALHO, A. Novo sistema de cultivar café. Boletim da superintendência dos serviços do café. v. $34, n^{0} 388$. p.16-17. 1959.

CARVALHO, A. Genética de Coffea. XXIV - Mutantes de Coffea arabica procedentes da Etiópia. Bragantia, $n^{\circ} 18, p .353-371,1959$.

CARVALHO, A.; ANTUNES FILHO, H. Novas observações sobre o dimorfismo dos ramos em Coffea arabica L. Bragantia, v.12, p.81-84, 1952. 
CARVALHO, A.; ESKES, A.B.; FAZUOLI, L.C. Breeding for rust resistance in Brazil. In: KUSHALAPPA, A.C.; ESKES, A.B. eds. Coffee rust: epidemology, resistance and management. Boca Raton: CRC press. 1989a. p. 295-307.

CARVALHO, A.; FAZUOLI, L.C. Café. In: FURLANI, A.M.C.; VIÉGAS, G.P. eds. O melhoramento de plantas no Instituto Agronômico. Campinas: IAC. 1993. p.29-76.

CARVALHO, A.; FAZUOLI, L.C.; COSTA, W.M. da. Melhoramento do Cafeeiro. XLI Produtividade do Híbrido de Timor, de seus derivados e de outras fontes de resistência a Hemileia vastatrix. Bragantia, $n^{\circ} 48$. p.73-86, $1989 \mathrm{~b}$.

CARVALHO, A.; KRUG, C.A.; MENDES, J.E.T.; ANTUNES FILHO, H.; MORAES, H.; ALOISI SOBRINHO, J.; MORAES, M.V.; ROCHA, T.R. Melhoramento do cafeeiro. IV - Café Mundo Novo. Bragantia, no 12, p.97-129, 1952.

CARVALHO, A.; MEDINA FILHO, H.P.; FAZUOLI, L.C.; COSTA, W.M. da. Número de logo e ação gênica de fatores para porte pequeno em Coffea arabica $L$. Bragantia, $n^{\circ} 43$, p.425442, 1984.

CARVALHO, A.; MEDINA FILHO, H.P.; FAZUOLI, L.C.; GUERREIRO FILHO, O.; LIMA, M.M.A. Aspectos genéticos do cafeeiro. Revista Brasileira de Genética, v. 14, $n^{\circ} 1$, p.135-183, 1991.

CARVALHO, A.; MONACO, L.C.; CAMPANA, M.P. Melhoramento do cafeeiro. XXVII - Ensaios de seleções regionais de Jaú. Bragantia, $n^{\circ} 23$, p.129-142, 1964.

CARVALHO, C.H.S. Relação entre a seca de ramos e a morte de raízes de progênie de Catimor UFV - 1359. Viçosa, 1985. 43p. Dissertação (MS) - Universidade Federal de Viçosa.

CARVALHO, M.M.; SOUZA, P. Comportamento de cafeeiros em diferentes sistemas de plantio, antes e após a recepa, em Lavras-MG. In: CONGRESSO BRASILEIRO DE PESQUISAS CAFEEIRAS, 5, Campos do Jordão, 1980. Resumos. Rio de Janeiro: IBC. 1980. p.399402.

CASTILHO, Z.T.; MORENO, R.G. La variedad Colombia: selección de um cultivar compuesto resistente a la roya sul cafeto. Chinchiné. Centro Nacional de Investigaciones de Café, 1987. 171p.

CHAVES, J.C.D. Estudos de culturas intercalares em cafezais recepados e em formação. In: CONGRESSO BRASILEIRO DE PESQUISAS CAFEEIRAS, 6, Ribeirão Preto, 1978. Resumos. Rio de Janeiro: IBC, 1978. p.125-127.

CORTES S. Influência de las altas densidades de plantación sobre la aoscion de los frutos de Coffea arabica L., a plena exposición solar. Cultivar Tropicalis. v. 7, p.155-169. 1985.

COSTA, W.M. da; FAZUOLI, L.C.; CARVALHO, A.; NUNES, J.B.P.; BARONI, R.L. Seleções regionais de Catuaí - Comportamento de populações na região da Alta Paulista. In: 
CONGRESSO BRASILEIRO DE PESQUISAS CAFEEIRAS. 10. Poços de Caldas, 1983. Resumos. Rio de Janeiro: IBC, 1983. p.104-105.

CLOWES, M.ST.J. Physiological die-back of coffee. Rhod. Agric. Journal. v. 70, p.85-86. 1973.

CRAMER, P.J.S. Gegevens over de variabiliteit van de in Neer der I. Batavia: Indie Verbowle Koffuscoten G. Kolff \& Co. 1913.696p.

DEPARTAMENTO DE INVESTIGACIONES EN CAFÉ. Trinta años al servicio de la cafeicultura costarricense. San José: Ministério de Agricultura y Ganaduia. 1980. 28p.

D'SOUZA, G.I. Studies on a die-back of arabica coffee in south India: Role of pest and parasites. Indian Coffee. v. 36, p.40-43, 1972.

FAZUOLI, L.C. Avaliação de progênies de café Mundo Novo (Coffea arabica L.). Piracicaba, 1977. 146p. Dissertação (M.S.) - Escola Superior de Agricultura "Luiz de Queiroz", Universidade de São Paulo.

FAZUOLI, L.C. Genética e Melhoramento do Cafeeiro. In: RENA, A.B.; MALAVOLTA, E.; ROCHA, M.; YAMADA, T. org. Cultura do Cafeeiro: fatores que afetam a produtividade. Piracicaba: Potafós, 1986. p.87-113.

FAZUOLI, L.C. Metodologia, critérios e resultados da seleção em progênies do café Icatu com resistência a Hemileia vastatrix. Campinas, 1991. 322p. Tese (Doutorado) - Universidade Estadual de Campinas.

FAZUOLI, L.C. Contribuição da pesquisa para a obtenção de cafeeiros adaptados ao plantio adensado. In: SIMPÓSIO INTERNACIONAL SOBRE CAFÉ ADENSADO, Londrina-PR, 1994. Anais. Londrina: IAPAR, 1994. p.3-43.

FAZUOLI, L.C.; LIMA, M.M.A.; GONÇALVES, W.; COSTA, W.M. da. Melhoramento do cafeeiro visando resistência a nematóides e utilização de porta-enxerto resistente. In: CONGRESSO PAULISTA DE AGRONOMIA, 6. Piracicaba, 1987. Anais. Piracicaba. p.171-180.

FERNANDES, D.R. Manejo do cafeeiro no Brasil. In: MALAVOLTA, E.; YAMADA, T.; GUIDOLIN, J.A. (eds.). Nutrição e adubação do cafeeiro. Piracicaba: POTAFÓS, 1983. p.55-76.

FERNIE, L.M. Coffee pruning. Kenya Coffee. v. 31, $n^{\circ} 364$, p.153-162. 1966.

FERNIE, L.M. Pruning and intensification. Kenya Coffee. v. 35, p.49-51, 1970.

FIGUEIREDO, P.; HIROCE, R.; CAMARGO, A.P.; MARIOTO, P.R.; FERNANDES, D.R.; BONINI, R. Controle de "seca de ponteiros" do cafeeiro 'Catuai', em Tejupá-SP., por fungicida, quebra-vento e adubação NK, avaliado pela produção. In: CONGRESSO 
BRASILEIRO DE PESQUISAS CAFEEIRAS, 8, Campos do Jordão, 1980. Resumos. Rio de Janeiro: IBC, 1980. p.191-193.

FIGUEROA, N.G. Evaluación del metodo de poda B.F. en ciclos de três, cuatro, cinco años, comparada con la poda selectiva por planta. Revista Cafetalera. $n^{\circ} 308$, p.25-26, 1990.

FISHER, N.M.; BROWNING, G. The water requirements of high density coffee. 1 - Responses to irrigation and plant water stress measurements. Kenya Coffee. v. 43, $n^{\circ}$ 503. p.43-46. 1978.

FISHER, N.M.; BROWNING, G. Some effects of irrigation and plant density on the water relations of Coffea arabica $L$. in Kenya. Journal of Horticultural Sciense. v. 54, p.13-22. 1979.

FNP-COLSULTORIA \& COMÉRCIO. Agrianual 96. São Paulo: Agros Comunicação, 1996. $392 p$.

GARCIA, A.M.; RIVAS, V.A.; BELLAVITA, M.O. Comparación de varias densidades de siembra en cafetales. Agronomia Tropical. v. 17, $n^{\circ} 3$, p.187-193. 1967.

GATHAARA, M.P.K. Tree performance at close spacing as influenced by pruning cycle and site. Kenya Coffee. v. 53, $n^{\circ} 626$, p.479-482. 1988.

GATHAARA, M.P.H. Pruning arabica coffee: some physiological aspecto to consider. Kenya Coffee. v. 61, $n^{\circ} 717$, p.2261-2262. 1996.

GATHAARA, M.P.K.; KIARA, J.M. Factors that influence yield in close-spaced coffee 1 - light, dry mather production and plant water status. Kenya Coffee. v. $49, n^{\circ} 578$, p.159-167. 1984.

GATHAARA, M.P.K.; KIARA, J.M. Factors that influence yield in close-spaced coffee 1 - Yield components. Kenya Coffee. v. 50, n 587, p.387-392. 1985.

GATHAARA, M.P.K.; KIARA, J.M. Density and fertilizer requerimento of compact and disease resistant arabica coffee. Kenya Coffee. v. 55, $n^{\circ} 646$, p.907-910. 1990.

GOPAL, N.H.; RAMAIAH, P.K. Studies on wilting and die-back arabica coffee plants. Indian Coffee. v. 35, p. 9, 1971.

GONÇALVES, W. Reações de cafeeiros (Coffea spp.) a Meloidogyne exigua Goeldi, 1987 e a diferentes populações de Meloidogyne incognita (Kofoid e White, 1919) Chitwood, 1949. Botucatu, 1993. 110p. Tese (Doutorado) - Universidade Estadual Paulista.

GONÇALVES, W.; FERRAZ, L.C.C.B. Resistência do cafeeiro a nematóides. II - Testes de progênies e híbridos para Meloidogyne incognita raça 3. Nematologia Brasileira, $n^{0} 11$, p.125-142, 1987.

GUERRA, D.A. Altura del corte de poda y su influencia sobre la brotación y produccion del cafeto. Café - Nicaragua. v. 249, p.19-21, 1972. 
GUTIÉRREZ, G.; PÉREZ, J.; CAMPOS, C.F. Relación entre la distancia de siembra y la fertilizacion del cafeto. In: CONGRESSO AGRONÔMICO NACIONAL, 2, San Jose, 1975. v. $1,3$.

HANGDONG, A.S.; BARTOLOME, R. The effect of spacing on the yield arabica coffee. Coffee and Cacao Journal. v. 9, $n^{\circ} 1$, p.10-18, 1966.

HANGDONG, A.S.; BERCOME, R. A progress report in the effect of spacing in the yield of arabica coffee. Coffee and Cacao Journal. v. 6, $n^{\circ} 3$, p. 53-55, 1963.

HENAO, A.V.; MESTRE, A.M. Efecto de la densidad de población y de la disposición de los árboles en la producción de café. Cenicafé, v.39, n.2, p.31-42. 1988.

HENRIQUEZ, C.N. Poda y estruturación de cafetales. In: ISIC. Técnicas modernas para el cultivo del café. San Salvador: Instituto Salvadoreño de Investigaciones del cafe (ISIC), 1983. p.44-61.

HERNANDEZ, P.M. Manual de Cafeicultura. Guatemala: ANACAFE, 1988. 247p.

HOLLIDAY, R. Plant population and crop yield. Field crop abstracts. v. 13, p.159-167. 1960.

HUERTA, A.; ALVIM, P. de I. Índice de área foliar y su influencia en la capacidad fotosintética del cafeto. Cenicafé. v. 13, p.75-84. 1962.

HUXLEY, P.A. Seminar on Intensification of coffee growing in Kenya, Nairobi, 1969. Proceedings. Ruiru: Coffee Research Foundation, 1968. 240p.

HUXLEY, P.A.; CANNELL, M.G.R. Some crop physiological factors to be consider in intensification. In: HUXLEY, P.A. (ed.). Intensification of coffee growing in Kenya. 1968. p.45-54.

IAC. Cultivares lançados pelo IAC no período 1968-1979. O Agronômico, n³2, p.39-168. 1980.

IAPAR. Café IAPAR 59. Londrina: IAPAR. 1993 (folder).

IBC. A moderna cafeicultura nos cerrados. Rio de Janeiro: IBC, 1987. 184p. Instruçóes técnicas sobre a cultura de café no Brasil, 21.

INSTITUTO SALVADOREÑO DE INVESTIGACIONES DEL CAFÉ. Manual del cultivo del cafe en El Salvador. 8p. 1976.

JAYARAMA; RAMAIAH, P.K. Standard fertiliser recomendations for coffee - A critical review based in soil and leaf analysis. Indian Coffee. v. 52, p.5-19, 1988.

JIMENEZ, A.E.; MARTINEZ, V.P. Estudios ecologicos del agroecosistema cafetaleno. II Producción de materia orgánica en diferentes tipos de estructura. Brotica, v. 4, p.109-126, 1979. 
KABAARA, M.A. Some systems of intensive coffee growing in South and Central America. In: COFFEE RESEARCH FOUNDATION. Annual Report 1968-1969. Ruiru: CRF. 1969. p.68.

KIARA, J.M. Response of two coffee cultivars to spatial arrangements at high density planting. Kenya Coffee. v. 46, $n^{\circ}$ 546, p.277-282. 1981.

KRUG, C.A.; CARVALHO, A. Genética de Coffea. XIII - Hereditariedade do caráter erecta em Coffea arabica L. Bragantia, $n^{\circ} 10$, p.321-328, 1950.

KRUG, C.A.; MENDES, J.E.T.; CARVALHO, A. Taxonomia de Coffea arabica L. Descrição das variedades e formas encontradas no Estado de São Paulo. Campinas, IAC, 1938. 57p. (IAC. Boletim Técnico, 62).

KRUG, C.A.; MENDES, J.E.T.; CARVALHO, A. Taxonomia de Coffea arabica L. II - Coffea arabica L. var. Caturra e sua forma xanthocarpa. Bragantia, v. 9, n 9-12, p.157-163, 1949.

KUGURU, K.M.; FISHER, N.M.; BROWNING, G.; MITCHELL, H.W. The effect of tree density on yield and some components of arabica coffee in Kenya. Acta Horticulture. v. 65, p.101113. 1978.

KUMAR, $O$. Investigation into some physiological aspects of high density plantings of coffee. Kenya Coffee. v. 43, p.263-272, 1978.

KUMAR, O. Some physiological aspects of the physiology of Coffea arabica L.A. review. Kenya Coffee. v. 44-47, 1979.

KUMAR, O.; TIESZEN, L.T. Some aspects of photosyntesis and related process in Coffea arabica L. Kenya Coffee. v. 4, $n^{\circ} 486$, p.309-315. 1976.

KUSHALAPPA, A.C.; ESKES, A.B. Coffee rust: epidemology, resistance and management. Boca Raton: CRC press. 1989. 345p.

LAZZARINI, W.; MORAES, F.R.P. Ensaio de espaçamento, número de pés e fertilização. In: REUNION LATINOAMERICANA DE FITOTECNIA, 7, Maracay, 1967. Resumos. Maracay: ALAF, 1967. p.33.

LAZZARINI, W.; MORAES, F.R.P.; TOLEDO, S.V.; FIGUEIREDO , J.I. Experimentação cafeeira 1929-1963. Campinas: IAC. 299p. 1967.

LEGUIZAMON, C.J.; ARCILA, P.J. Secamiento de ramas y frutos del cafeto y su relación con la roya. Chinchiná: CENICAFE, 1981. (CENICAFE. Avances Técnicos, 166).

LIBRAN, D.L.; MORALES, D.; CORTES, S. Estudio preliminar sobre la intensidad transpiratória del cafeto cultivado a diferentes densidades de plantación. Cultivos Tropicales. v. 7 , p.109-115. 1985.

MALAVOLTA, E. Nutrição mineral e fertilização do cafeeiro. In: SIMPÓsIO SOBRE CAFEICULTURA LATINOAMERICANA, 44, Heredia, 1990 (mimeo). 
MALAVOLTA, E.; GOMES, F.P.; COORY, T. Estudos sobre a alimentação mineral do cafeeiro Coffea arabica L. Variedade Bourbon Vermelho. Anais da E.S.A. "Luiz de Queiroz", v. 22, p.82-93, 1958 .

MANSK, Z.; MATIELLO, J.B.; ANDRADE, I.P.R.; ABREU, R.G. Seca de ramos ponteiros em cafezais no Estado do Espírito Santo causada por Phoma spp. In: CONGRESSO BRASILEIRO DE PESQUISAS CAFEEIRAS, 3. Rio de Janeiro, 1975. Resumos. Rio de Janeiro: IBC, 1975. p.43-45.

MARTIN, N.B.; VEGRO,C.L.R.;MORICOCHI,L. Custos e rentabilidade de diferentes sistemas de produção de café, 1995.Informações Econômicas, v. 25, n. 8, p 35-47. 1995.

MATIELLO, J.B. O café: do cultivo ao consumo. São Paulo. ed. Globo, 1991. 320p. (Coleção do agricultor).

MATSUNAGA,M. Alternativas tecnológicas na cultura do café no Estado de São Paulo. São Paulo, 1981. 160 p. Dissertação (M.S.) Faculdade de Economia e Administração, Universidade de São Paulo.

MELLES, A.C.; CHEBABI, M.M.A.; NACIF, A. de P.; GUIMARÁES, P.T.G. Culturas intercalares em lavouras cafeeiras nas fases de formação e produção. Informe Agropecuário. v. 126, p. $62-65,1985$.

MELLES, A.C.; GUIMARÃES, P.T.G. Podas do cafeeiro. Informe Agropecuário, v. 126, p.6975,1985

MIGUEL, A.E.; MATIELLO, J.B.; ALMEIDA, S.R. Espaçamento condução do cafeeiro. In RENA, A.B.; MALAVOLTA, E.; ROCHA, M.; YAMADA, T. (eds.). Cultura do cafeeiro: fatores que afetam a produtividade. Piracicaba: POTAFÓS, 1986. p.308-322.

MIGUEL, A.E.; REIS, G.N.; MATIELLO, J.B.; OLIVEIRA, J.A. Estudo da distância entre mudas de café na cova, em diferentes espaçamentos na linha (entre cova). In: CONGRESSO BRASILEIRO DE PESQUISAS CAFEEIRAS, 14, Campinas, 1987. Resumos. Rio de Janeiro: IBC. 1987. p.131-133.

MIGUEL, J.C.T.; PAULINO, A.J.; MATIELLO, J.B.; JABOR, J.F.; BRAGANÇA, J.B. Comparação entre sistemas de plantios condensado e tradicional. In: CONGRESSO BRASILEIRO DE PESQUISAS CAFEEIRAS, 10, Poços de Caldas, 1983. Resumos. Rio de Janeiro: IBC, 1983. p.204-206.

MINISTÉRIO DE AGRICULTURA Y GANADERIA, Costa Rica. Departamento de Café. Informe Anual de Labores 1967. 64p. 1968.

MITCHELL, H.W. Research on close spacing system for intensive coffee production in Kenya I Kenya Coffee, v. 41, $n^{\circ} 481$, p.124-136, 1976a. 
MITCHELL, H.W. Research on close spacing system for intensive coffee production in Kenya II.

Kenya Coffee, v. 41, $n^{\circ} 482$, p.168-174, $1976 b$.

MITCHELL, H.W. Research on close spacing system for intensive coffee production in Kenya III.

Kenya Coffee, v. 41, $n^{\circ} 484$, p.241-244, 1976c.

MITCHELL, H.W. Research on close spacing system for intensive coffee production in Kenya IV. Kenya Coffee, v. $41, n^{\circ} 485$, p.281-239, $1976 d$.

MONACO, L.C.; CARVALHO, A. Coffee breeding for leaf rust resistance. In: COLLOQUE INTERNATIONAL SUR LA CHIMIE DES CAFÉS. 7, Hambourg, 1975. Hambourg: ASSIC, 1975. p.437-445.

MONACO, L.C.; CARVALHO, A.; ROCHA, T.R. Melhoramento do cafeeiro. XXVIII - Ensaios de seleções regionais em Mococa. Bragantia, $n^{\circ} 24$, p.9-27, 1965.

MONTENEGRO, G.L. Distanciamento de siembra del cafeto y su efecto sobre la producción. Boletim Informativo. El Salvador, $n^{\circ} 42$, p.1-2, 1962.

MORICOCHI,L.;MARTIN,N.B. As perspectivas da cafeicultura brasileira pós-acordo internacional. Informações Econômicas. v. 23, n. 8, p. 35-39. 1993.

MWAKHA, E. Intercopping dry beans in high density arabica coffee. II - Response to bean rows and nitrogen fertilizer. Kenya Coffee. v. 45, $n^{\circ}$ 536, p.319-324. 1980.

NJOROGE, J.M.; KIMEMIA, J.K. Influence of tree training and plant density on yields of an improved cultivars of Coffea arabica. Experimental Agriculture. v. 30, $n^{\circ} 1$, p.89-94.

NJOROGE, J.M.; MWAKHA, E. Influence of nitrogen fertizer and plant density on growth and yield of Arabica coffee during the fint production cycle in Kenya. Discovery and Inovation, v. $5, n^{\circ} 3$, p.235-239. 1993.

OBANDO, J.J.J. Practicas Culturales. In: ICAFE/MAG. Cuarenta años de investigación y transferencia de tecnología en café. San José: ICAFE/MAG, 1990. p.27-36.

OFICINA DEL CAFÉ. Informe anual de labores del programa cooperativo. San Jose: OFFICAFE/MAG, 1982. 170p.

OCTAVIO, F.S. Muerte descendente de los brotes del cafeto causada por especies de Phoma y Colletotrichum. Cenicafé, v. 12, p.127-140. 1961.

OLIVEIRA, J.A.; MATIELLO, J.B.; MIGUEL, A.E. Curvas de produção de cafeeiros Catuaí em ensaios de espaçamentos progressivos na Zona da Mata de Minas Gerais. In: CONGRESSO BRASILEIRO DE PESQUISAS CAFEEIRAS, 16, Espirito Santo do Pinhal, 199. Resumos. Rio de Janeiro: IBC, 1990. p.32-34.

PAVAN, M.A.; CHAVES, J.C.D.; ANDROCIOLLI FILHO, A. Produtividade do cafeeiro em função de algumas práticas culturais. In: CONGRESSO BRASILEIRO DE PESQUISAS 
CAFEEIRAS, 16, Espírito Santo do Pinhal, 1990. Resumos. Rio de Janeiro: IBC. 1990. p.87.

PAVAN, M.A.; CHAVES, J.C.D.; ANDROCIOLLI FILHO, A. Produção de café em função da densidade de plantio, adubação e tratamento fitossanitário. Turrialba. v. $44, n^{\circ} 4$, p.227$231,1994$.

PAVAN, M.A.; CHAVES, J.C.D.; SIQUEIRA, R.; ANDROCIOLLI FILHO, A.; ROTH, C.H. Manejo da densidade populacional de cafeeiro como fatos melhorados da fertilidade do solo e da produtividade. In: CONGRESSO BRASILEIRO DE PESQUISAS CAFEEIRAS, 17, Varginha, 1991. Resumos. Rio de Janeiro: MAARA, 1991. p.24.

PAVAN, M.A.; CHAVES, J.C.D.; SIQUEIRA, R.; ANDROCIOLLI FILHO, A.; ROTH, C.H. Densidad de población de cafetos influenciando la fertilidad del suelo. In: SIMPÓSIO DE CAFEICULTURA LATINOAMERICANA, 16, Managua, 1993. Anais. Managua: IICA/PROMECAFÉ, 1993. p.112.

PIMENTEL GOMES, F. Iniciação à Estatística. São Paulo: Nobel, 1976. p.222-223.

PIMENTEL GOMES, F. Curso de Estatistica Experimental. São Paulo: Nobel. 12 ed. 1987. $467 p$.

PRASIT, V.; AKSORN, S. Kan suksa rabop khong kan tattaeng king lae raya pluk khong kafae arabica phan Red Caturra. In: Raingan phon kan prachum choeng patibatkan nganwichai phua phatthana kafae bon thi sung khrong thi 3 ruang "Technology kafae arabica. Chiang Mai, 1986. Resumos. Chiang Mai: Chiang Mai University. Faculty of Agriculture. 1986. p.17.

RAYNER, R.W. Growth and bearing habits of Coffea arabica in Kenya and in Southern India. E.A. Agric. Journal. v. 11, p.251-255. 1946.

RENA, A.B.; PEREIRA, A.A.; BARTHOLO, G.F. Teor foliar de minerais, conteúdo caulinar de amido e o depauperamento de algumas progênies de café resistentes à ferrugem. In: CONGRESSO BRASILEIRO DE PESQUISAS CAFEEIRAS, 10. Poços de Caldas, 1983. Resumos. Rio de Janeiro: IBC, 1983. p.169-170.

RIVERA, R. Crescimento, nutrición y fertilización ( $N, P, K)$ del cafeto a plena exposición solar, sobre suelos fenalíticos rojos - Principales resultados obtenidos por el INCA en el período 1973-1989. Cultivos Tropicales. v. 14, n² 2, 3, p.5-36. 1993.

RODRIGUEZ, S.J.; BOSQUE, L.R.; PEREZ, P.R.; MORALES, M.A. Effect of planting distances on shaded coffee yield in Puerto Rico. The Journal of Agricultura of the University of Puerto Rico. v. 50, $n^{\circ} 2$, p.82-86. 1966.

RODRIGUEZ JÚNIOR, C.T; BETTENCOURT, A.J.; RIJO, L. Races of the pathogenes and resistance to coffee rust. Annual Review of Phytopathology, $n^{\circ} 13, p .49-70,1975$. 
ROMERO, J.P.; ROMERO, J.P. Cafezal adensado - Recordando (espaçamentos) juntos. In: SIMPÓSIO INTERNACIONAL SOBRE CAFÉ ADENSADO, Londrina, 1994. Anais. Londrina: IAPAR, 1994, p.279-280.

ROOSTER, K. Coffee research in the Transvaal lowved: pruning systems. Nelspruit: Citrus and Subtropical Fruit Research Institute, Information Bulletin 44. p.3-4. 1976.

SALAZAR, A.N.; MESTRE, M.A. Efecto de la distancia de siembra sobre la produccion de Coffea arabica var. Bourbon. Cenicafé. v. 28, $n^{\circ} 1$, p.27-35. 1977.

SALISBURY, F.B.; KOSS, C.W. Plant physiology. Berkley: words worth Inc, 1978. 320p.

SANTINATO, R.; MATIELLO, J.B.; SILVA, W.J.; CARVALHO, R.; CAMARGO, R.; SHIMUSAKA, M. Espaçamentos (hiper, super e adensado na rua e na linha de plantio para cafeeiros resistentes à ferrugem, variedades Icatu 2944, Catucaí e Mundindu. In: CONGRESSO BRASILEIRO DE PESQUISAS CAFEEIRAS, 20. Guarapari, 1994. Resumos. Rio de Janeiro: MAARA/PROCAFÉ. 1994. p.176-180.

SCARANARI, H.J. Espaçamentos para o cafeeiro. Boletim da superintendência dos serviços do café. v. $33, n^{\circ} 375$, p.45-46. 1958.

SCARANARI, H.J.; NOGUEIRA NETO, P. Efeito da densidade de plantio sobre a produção de café "Mundo Novo". Bragantia. v. 22, $n^{\circ}$ 1, p.373-382. 1963.

SEGURA, A. Algunas caracteristicas fisiológicas del cafeto y su relación con la nutrición mineral. In: SEMINÁRIO TALLER SOBRE NUTRICIÓN MINERAL DEL CAFETO, Guatemala, 1989. Anais. Guatemala: IICA/PROMECAFÉ, 1989, p.1-6.

SEGURA, M.A. Algunas consideraciones agrofisiológicas in relación a la pode de los cafetos: Experiências con cafetales con alta densidad de siembra. In: SIMPÓSIO INTERNACIONAL SOBRE CAFÉ ADENSADO, Londrina-PR, 1994. Anais. Londrina: IAPAR, 1994. p.199-220. SIQUEIRA R.; ANDROCIOLI FILHO, A. Ajuste de espaçamento adensados para cultivares de Coffea arabica L. (Catuaí e Mundo Novo) em Londrina-PR. In: CONGRESSO BRASILEIRO DE PESQUISAS CAFEEIRAS, 17, Varginha, 1991. Resumos. Rio de Janeiro: IBC. 1994. p.34-35.

SIQUEIRA, R.; ANDROCIOLI FILHO, A.; CARAMORI, P.H.; PAVAN, M.A. Espaçamento e produtividade do cafeeiro. Londrina: IAPAR, 1985. 5p. (IAPAR. Informe de pesquisa, 56). SIQUEIRA, R.; ANDROCIOLI FILHO, A.; CARAMORI, P.H.; PAVAN, M.A. Efeito de oito densidades de plantio na produtividade de três cultivares de café (Coffea arabica L.) e do híbrido Icatú. In: CONGRESSO BRASILEIRO DE PESQUISAS CAFEEIRAS, 16, Espírito Santo do Pinhal, 1990. Resumos. Rio de Janeiro: IBC. 1990. p.86. 
SIQUEIRA, R.; ANDROCIOLI FILHO, A.; PAVAN, M.A.; CHAVES, J.C.D. Densidade de plantio, poda dos primeiros ramos e produção de duas cultivares de café e do híbrido "Icatu". Pesq. Agrop. Bras. v. 18, p.763-769, 1987.

SOENARJO. Percobaan sistim pangkas Beaumont-Fukunaga pada kopi robusta. MenaraPerkebunan. v. 42, $n^{\circ}$ 5, p.237-242, 1934./Resumo em CAB abstracts on CD-ROM/.

SOENARJO; SOELISTYO. Percobaan jarak tanam dan rapatnya tanaman pada kopi arabica (Coffea arabica L.). Menara Perkebunan. v. 44, $n^{\circ} 4$. p.185-190. 1976. /Resumo em CAB Abstract on CD-ROM/.

SOTO, B. Modalidades de cultivo. In: DEPARTAMENTO DE INVESTIGACIONES EN CAFÉ. Treinta años al servicio de la cafeicultura Costarricense. San Jose: Ministério de Agricultura y Ganaderia. 1980. p.10-15.

STRAUCH, M.E.; MESTRE, M.A. Influência de algumas practicas sobre la brotacion en la renovación por "recepa" o "soqueo" del cafeto. Cenicafé. v. 3, p.63-72, 1972.

THOMAZIELLO, R.A.; OLIVEIRA, E.G.; TOLEDO FILHO, J.A.; COSTA, T.E. Cuitura do café. Campinas: CATI, 1996. 69p. (Boletim Técnico 193).

TOLEDO, A.R.; MIGUEL, A.E.; MATIELLO, J.B. Estudos de diversos espaçamentos no plantio do cafeeiro - Mundo Novo LCP 379/19- Resultado de sete colheitas. In: CONGRESSO BRASILEIRO DE PESQUISAS CAFEEIRAS, 16, Espírito Santo do Pinhal, 1990. Resumos. Rio de Janeiro: IBC. 1990. p.118-119a.

TOLEDO, A.R.; MIGUEL, A.E.; MATIELLO, J.B. Efeito da redução do espaçamento entre ruas na linha, no cultivar Catuaí - resultado de quatro colheitas - Varginha-MG. In: CONGRESSO BRASILEIRO DE PESQUISAS CAFEEIRAS, 16, Espírito Santo do Pinhal, 1990. Resumos. Rio de Janeiro: IBC. 1990. p.120-121b.

TOLEDO, A.R.; MIGUEL, A.E.; MATIELLO, J.B.; ALMEIDA, S.R. Estudo de diversos espaçamentos adensados com vários sistemas de podas em relação ao plantio tradicional cultivar Mundo Novo - Acaiá - no sul de Minas Gerais. In: CONGRESSO BRASILEIRO DE PESQUISAS CAFEEIRAS, 15, Maringá, 1989. Resumos. Riode Janeiro: IBC. 1989. p.143144.

TOLEDO, A.R.; MIGUEL, A.E.; MATIELLO, J.B.; ALMEIDA, S.R. Tipos de podas de condução em plantios adensados de café Catuaí e efeitos na produção - resultados de 12 colheitas. In: CONGRESSO BRASILEIRO DE PESQUISAS CAFEEIRAS, 19. Três Pontas. 1993. Resumos. Rio de Janeiro: MAARA/PROCAFE. 1993. p.100-101.

TOLEDO, A.R.; MIGUEL, A.E.; METIELLO, J.B.; ALMEIDA, S.R. Tipos de podas de condução no sistema de plantio de café adensado nos cultivares Mundo Novo e Catuaí - Resultado 
das seis primeiras colheitas. In: CONGRESSO BRASILEIRO DE PESQUISAS CAFEEIRAS, 14. Campinas, 1987. Resumos. Rio de Janeiro: IBC, 1987. p.197-198.

TOLEDO, S.V. Espaçamento, número de plantas por cova e condução da planta e seus efeitos na produção de cafeeiros Mundo Novo. In: CONGRESSO BRASILEIRO DE PESQUISAS CAFEEIRAS, 7, Araxá. 1979. Resumos. Rio de Janeiro: IBC, 1979. p.47-50.

URIBE, H.A.; MESTRE, M.A. Efecto de la densidad poblacional y su sistema de manejo sobre la producción de café. Cenicafé. v. 31, p.29-51, 1980.

URIBE, H.A.; MESTRE, M.A. Efecto de la distância de siembra y del número de plantas por hoyo sobre la producción de café (Coffea arabica L. var. Vaturra). Cenicafé. v. 39, p.15-27, $1988 \mathrm{a}$.

URIBE, H.A.; MESTRE, M.A. Efecto de la densidad poblacional y da disposição de los árboles en la producción de café. Cenicafé. v. 31, p.31-42, 1988b.

URIBE, H.A., SALAZAR, A.M. Distancias de siembra y doses de fertilizante en la producción de café. Cenicafé. v. 32, $n^{\circ} 3$, p.88-105. 1981.

VALENCIA, A.G. Relación entre el índice de área foliar y la produtividad del cafeto. Cenicafé. v. 23, p.74-89. 1973.

VIANA, A.S.; CAMARGO, A.P.; FREIRE, D. Efeito de espaçamentos progressivos na produção de café por cova e por área. In: CONGRESSO BRASILEIRO DE PESQUISAS CAFEEIRAS, 11, Londrina, 1984. Resmos. Rio de Janeiro: IBC. 1984. p.171-174.

WILLSON, K.C. Cultural Methods. In: CLIFFORD, M.N.; WILLSON, K.C. (eds.). Coffee: botany, biochemistry and production of bean and beverage. Beckenham: Croom Helm, 1985. p.157-207.

WOKMER, T.M.; GITUANJA, J. Seasonal patterns $\mathrm{p} /$ growth and development of Arabica coffee in Kenya: II Flower initiation and diferentiation. Kenya Coffee, v. 35, p.270-2277. 1970.

WORMER, T.M.; GITUANJA, J. Floral initiation and flowering of Coffea arabica L. in Kenya. Exploratory Agriculture. v. 6, p.187-170. 1970. 


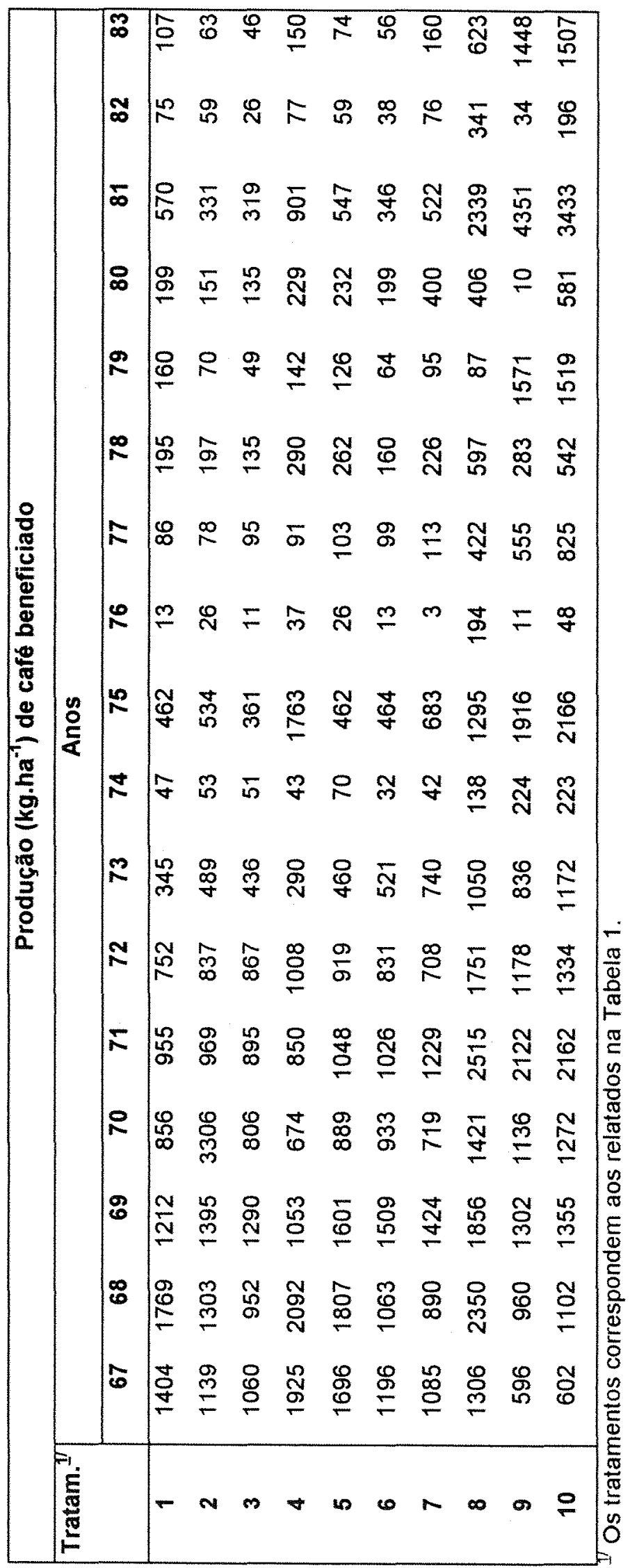




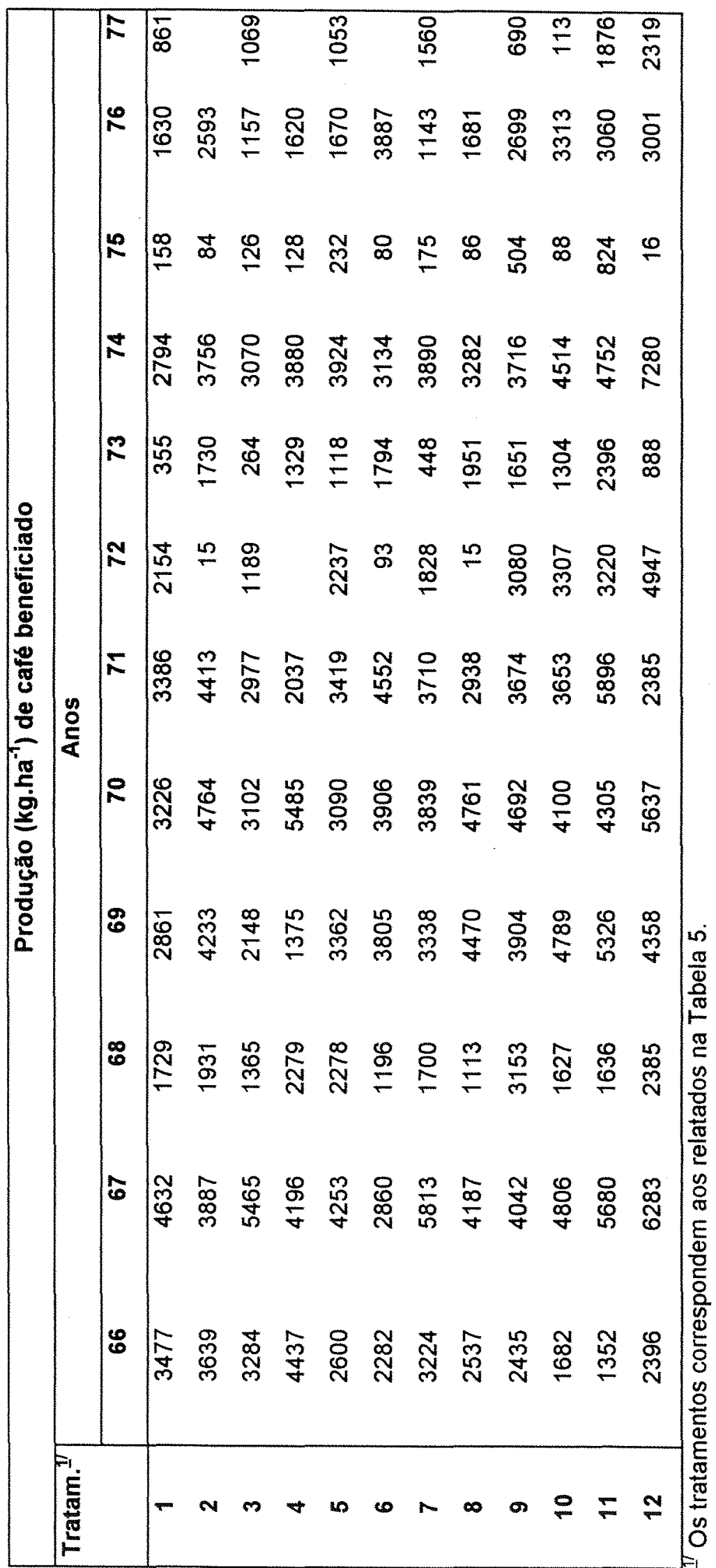

